\title{
Origin and Character of Loesslike Silt in the Southern Qinghai-Xizang (Tibet) Plateau, China
}


Cover. View south-southeast across Lhasa He (Lhasa River) flood plain from roof of Potala Palace, Lhasa, Xizang Autonomous Region, China. The Potala (see frontispiece), characteristic symbol of Tibet, rises $308 \mathrm{~m}$ above the valley floor on a bedrock hill and provides an excellent view of Mt. Guokalariju, 5,603 m elevation, and adjacent mountains $15 \mathrm{~km}$ to the southeast. These mountains of flysch-like Triassic clastic and volcanic rocks and some Mesozoic granite characterize the southernmost part of Northern Xizang Structural Region (Gangdese-Nyainqentanglha Tectonic Zone), which lies just north of the Yarlung Zangbo east-west tectonic suture $50 \mathrm{~km}$ to the south (see figs. 2, 3). Mountains are part of the Gangdese Island Arc at south margin of Lhasa continental block. Light-tan areas on flanks of mountains adjacent to almost vegetation-free flood plain are modern and ancient climbing sand dunes that exhibit evidence of strong winds. From flood plain of Lhasa He, and from flood plain of much larger Yarlung Zangbo to the south (see figs. 2, 3, 13), large dust storms and sand storms originate today and are common in capitol city of Lhasa. Blowing silt from larger braided flood plains in Pleistocene time was source of much loesslike silt described in this report. Photograph PK 23,763 by Troy L. Péwé, June 4, 1980. 
ORIGIN AND CHARACTER OF LOESSLIKE SILT IN THE SOUTHERN QINGHAI-XIZANG (TIBET) PLATEAU, CHINA 


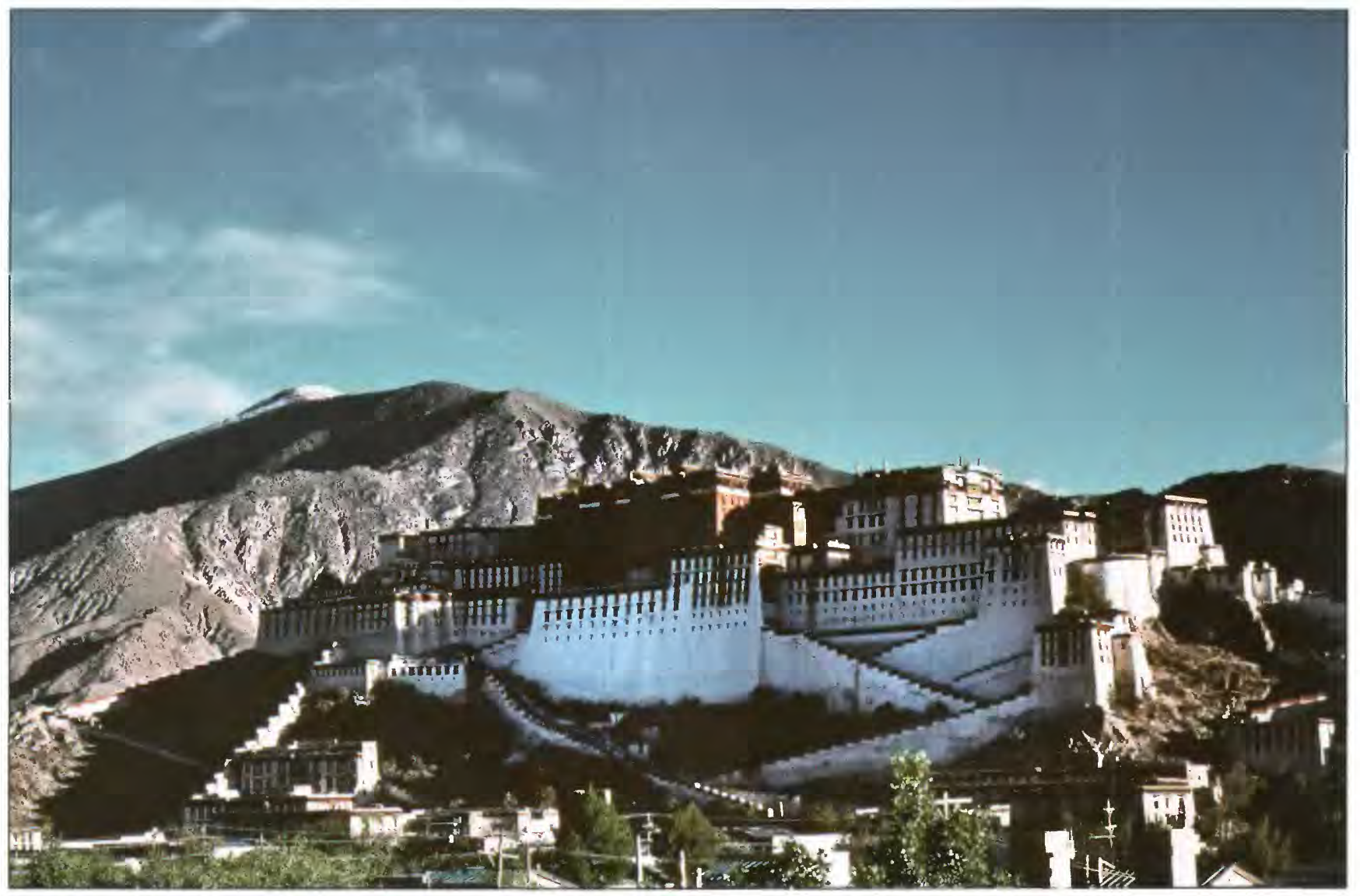

Frontispiece. On a 130-meter-high bedrock hill of Mesozoic limestone and schist, the splendid 13-story Potala Palace rises 308 meters above flood plain of the Lhasa He (Lhasa River) in Lhasa, capitol city of Xizang Autonomous Region, China. Construction of this well-known symbol of Tibet started in the 7th century, and most work took place under the direction of the fifth Dalai Lama from 1645 to 1693 . The Potala served as home for the fifth and later Dalai
Lamas and about 1,000 monks. The striking 1,000-room structure today is a state historical museum with about 35 caretaker monks. Roof provides a spectacular view of terrain of the southern QinghaiXizang (Tibet) Plateau (cover photograph). North Mountain, in the distance, consists of coarse-grained biotite granite of the Gangdese batholith of late Cretaceous and Palaeogene age; view to northwest. Photograph PK 23,739 by Troy L. Péwé, June 3, 1980. 


\section{Origin and Character of Loesslike Silt in the Southern Qinghai-Xizang (Tibet) Plateau, China}

By T.L. Péwé, Liu Tungsheng, Roger M. Slatt, and Li Bingyuan

\section{U.S. GEOLOGICAL SURVEY PROFESSIONAL PAPER 1549}

Retransported, tan, loesslike silt is widespread in the southern Qinghai-Xizang (Tibet) Plateau. On low hilltops the silt is primary loess. On the lower slopes and in valley bottoms of the major river valleys, however, it is poorly to well-stratified retransported loesslike silt. The silt probably was originally deposited by winds blowing across broad vegetation-free flood plains. 


\title{
U.S. DEPARTMENT OF THE INTERIOR BRUCE BABBITT, Secretary
}

\author{
U.S. GEOLOGICAL SURVEY \\ Gordon P. Eaton, Director
}

\author{
For sale by \\ U.S. Geological Survey, Information Services \\ Box 25286, Federal Center \\ Denver, CO 80225
}
Any use of trade, product, or firm names in this publication is for descriptive purposes only and does not imply endorsement by the U.S. Government.
Text and illustrations edited by Mary Lou Callas Line drawings by Susan M. Selkirk unless otherwise noted
Other graphics production by Susan M. Mayfield
Layout by Linnea Larsen

Library of Congress Cataloging-in-Publication Data

Origin and character of loesslike silt in the southern Qinghai-Xizang (Tibet) Plateau, China / by Troy L. Péwé ... [et al.].

p. $\quad \mathrm{cm}$. - (U.S. Geological Survey professional paper ; 1549)

Includes bibliographical references.

1. Loess-China-Tibet, Plateau of. I. Péwé, Troy Lewis, 1918-. II. Series.

QE579.075 1995

$552^{\prime} .5-\mathrm{dc} 20$ 


\section{CONTENTS}

Abstract
Introduction
Acknowledgments
Physical setting
Physiography and general geology
Climate

\section{FRONTISPIECE}

Frontispiece. Potala Palace and bedrock hills in Lhasa, Xizang Autonomous Region, China

\section{FIGURES}

1. Map showing distribution of loess in China and location of Qinghai-Xizang (Tibet) Plateau 
2. Landform and index maps of western China.

3. Index map of south-central Qinghai-Xizang (Tibet) Plateau.

4. Photograph of steam rising from wells in post-middle Pleistocene Yangbajain thermal field, $90 \mathrm{~km}$ northwest of Lhasa.

5. Map showing distribution of existing glaciers and snow-line elevations in China.

6. Generalized precipitation and vegetation map of Xizang Autonomous Region

7-9. Climatic data for:

7. Lhasa (1951-1980)

8. Xigaze (1955-1980)

9. Tingri (1970-1980)

10. Map showing distribution of permafrost and seasonally frozen ground in China ........................................... 14

11-20. Photographs showing:

11. Eroded remnant of frost blister exposing part of an ice core

12. Broad flood plain of a north-flowing tributary of the Yarlung Zangbo about $40 \mathrm{~km}$ west of Xigaze.......

13. Broad flood plain of Yarlung Zangbo about $15 \mathrm{~km}$ downstream from Xigaze

14. View southeast (upstream) of west side of Nyang Qu valley.....

15. Active sand dunes on flood plain of Nyang Qu about $7 \mathrm{~km}$ southeast of Xigaze .................................. 17

16. Climbing sand dunes on lower flanks of hills along braided Lhasa He ................................................. 18

17. Sharply dissected fans of retransported loess at base of low west-facing mountains east of Tingri, Xizang Autonomous Region.

18. Large dissected fan of retransported loess below site of Tibetan monastery and Xigar-Zhong at Tingri, south-central Xizang Autonomous Region, 1980 and 1922

19. Newly made bricks of loess and loess-brick walls $45 \mathrm{~km}$ southeast of Xigaze.

20. Remnants of loess-brick walls of 13 th century monastery about $10 \mathrm{~km}$ west of Xigaze.

21. Diagrammatic sketch of typical dissected loesslike silt with lenses and layers of fluvial sand and gravel in valley bottoms

22-24. Photographs of:

22. Loess overlying bedrock on knob $15 \mathrm{~m}$ above Nyang Qu at Xigaze.....

23. Deep, sharp-walled gully dissected into retransported loess fan at base of limestone knob east of Xigaze.

24. Alluvial fan of retransported loess sharply dissected by steep-walled gullies east of Xigaze.

25. Physiographic diagram of Xigaze area at junction of Nyang Qu and Yarlung Zangbo.

26. Photograph of flat-topped, steep-walled remnant of bedded, vertically jointed retransported loess in Nyang Qu valley north of Xigaze.

27. Sketch map of flood plain and stratigraphic sections of retransported sandy loess on terrace on south side of Xigaze.

28. Photograph of cliff-forming retransported tan loess exposed in road cut on south side of Xigaze .....

29. Triangular diagram showing proportions of sand, silt, and clay in sediment samples from south-central Qinghai-Xizang (Tibet) Plateau and a loess sample from Germany

30-33. Graphs showing cumulative-frequency grain-size curves for:

30. Retransported loesslike silt in southern part of Qinghai-Xizang (Tibet) Plateau...

31. Loess flanking or on top of bedrock knobs near Yarlung Zangbo and loesslike silt from Xizang Autonomous Region

32. Clay-rich retransported loess, south-central Qinghai-Xizang (Tibet) Plateau ...

33. Eolian and fluvial sand, south-central Qinghai-Xizang (Tibet) Plateau

34. Generalized geologic map of valley of Yarlung Zangbo and vicinity and weighted peak-percentage diagrams of clay minerals and major minerals

35. X-ray diffractograms of samples of loess and underlying volcaniclastic sandstone and lithic tuff

36. Diagram showing pollen composition of sediment samples from stratigraphic section on scarp of terrace of Nyang Qu.....

37. Photograph of collecting fossils in loesslike silt at river-terrace exposure on south side of Xigaze

38. Photograph of fresh-water gastropods Radix auricularia (L.) from loesslike silt south of Xigaze 
39. Cumulative-frequency grain-size curves for loess and retransported silt from near Xigaze and for volcanic ash and modern wind-blown dust from other parts of the world

40. Cumulative-frequency grain-size curves for loess and retransported silt from near Xigaze, from Beijing, and from other parts of the world

41. Photograph of ruins of ancient city of Jiaohe near Turpan, Xinjiang Uygur Autonomous Region

42. Block diagram showing retransported loess in valley beside ruins of Jiaohe

43. Photograph of narrow steep-walled valley entrenched in retransported loess on west side of Jiaohe

44. Low oblique aerial photograph of mesa-like remnants of retransported loess at ruins of Jiaohe near Turpan

45. Cumulative-frequency grain-size curves for loess and retransported loess from Kuqa (Kucha), Jiaohe, and Nilka, south and north flanks of Tian Shan, and from Xigaze area .

46. Schematic block diagram of loess and retransported loess north of Nilka, in Ili He valley on north slope of Tian Shan.

\section{TABLES}

1. Data on Quaternary sediment samples collected in southern Qinghai-Xizang (Tibet) Plateau

2. Mechanical properties of sand and loesslike silt from southern Qinghai-Xizang (Tibet) Plateau

3. Percentage of sand, silt, and clay in sand and loesslike silt, southern Qinghai-Xizang (Tibet) Plateau

4. Mineral compositions of $>0.062-\mathrm{mm}$ fraction of sand and loesslike silt, southern Qinghai-Xizang (Tibet)

Plateau

5. Mineral composition of bulk samples of sand and loesslike silt, southern Qinghai-Xizang (Tibet) Plateau

6. Mineral composition by weighted peak-area percentages of $<0.005-\mathrm{mm}$ fraction of sand and loesslike silt, southern Qinghai-Xizang (Tibet) Plateau 



\title{
Origin and Character of Loesslike Silt in the Southern Qinghai-Xizang (Tibet) Plateau, China
}

\author{
By Troy L. Péwé, ${ }^{1}$ Liu Tungsheng, ${ }^{2}$ Roger M. Slatt, ${ }^{3}$ and Li Bingyuan ${ }^{4}$
}

\begin{abstract}
Tan loesslike silt of probable late Quaternary age is widespread in the southern Qinghai-Xizang (Tibet) Plateau $^{5}$ of southwest China. Most of the silt has been retransported and occurs mainly in the lowlands and lower slopes; it is absent from steep slopes and active flood plains. This loesslike silt covers most alluvial fans and is interbedded with the sand and gravel of the fans. It is well exposed in the agricultural fields on low terraces in the valleys and in the steep-walled scarps of dissected valley fill. On low hilltops the silt is primary loess, probably deposited by winds that picked it up from broad vegetationfree flood plains and perhaps from dry lake basins to the north. In the lowlands, most of it is retransported loess that has been carried downslope and redeposited by water.

The primary loess is as thick as $6 \mathrm{~m}$ on hilltops or high flanks of hills and as thick as 10 to $15 \mathrm{~m}$ on the lower slopes. The thickest deposits are near the rivers in valley bottoms, where they develop vertical cliffs as high as $15 \mathrm{~m}$.

The texture and mineral composition of the primary loess is relatively uniform; however, the retransported loess varies widely in texture. The silt is clay rich to sand rich, and some is even gravel rich, depending on how near the original loess source was, on the distance of retransportation, and on the amount of mixing with other sediments by fluvial action. The silt is massive, and erosion

\footnotetext{
${ }^{1}$ Present address: Arizona State University, Box 871404, Tempe, AZ 85287-1404, U.S.A.

2 Institute of Geology, Academia Sinica, P.O. Box 634, Beijing, 100029, People's Republic of China.

${ }^{3}$ Colorado School of Mines, Golden, CO 80401, U.S.A.

4 Institute of Geography, Academia Sinica, P.O. Box 771, Beijing, 100101, People's Republic of China.

${ }^{5}$ The term for the Tibet Plateau that is approved by the U.S. Board on Geographic Names is "Qing Zang Gaoyuan". However, the term "Qinghai-Xizang (Tibet) Plateau" is most widely used in international scientific English-language publications and is used in this report.
}

Manuscript approved for publication May 18, 1994. forms vertical cliffs and deep gullies. It has little or no stratification or jointing, except where it has been retransported to lower slopes and valley bottoms where it is well to poorly stratified.

The few fossils that have been found in the loesslike silt on the plateau include Quaternary pollen, ostracodes, gastropods, and vertebrate teeth and bones. They reflect a dry cold area with a few ponds or marshes.

Through the years, the origin of the loesslike silt on the plateau has been ascribed to in situ weathering of residual country rock as well as to lacustrine, fluvial, or eolian processes. The weathering or residual hypothesis has little support. The lacustrine hypothesis, either separately or in conjunction with fluvial processes, has been considered since the late 1970's and the 1980's. The eolian process was first proposed in the 1980's.

Since the early 1930's the loesslike silt has been described as a residual deposit formed by the breakdown by freezing and thawing of the underlying rocks. However, the silt bears no chemical, mineralogical, or textural relation to the underlying strata, and it is too thick to represent only a breakdown of rocks in place.

The most common explanation in the literature for the origin of these thick deposits of loesslike sediments, especially in valley bottoms, is by lacustrine processes. This origin is unlikely, however, because no shorelines, wave-cut beaches, deltas, mud cracks, or ripple marks have been found in the silt deposits. Neither lacustrine stratification nor an appreciable amount of clay exists in the silt. Moreover, the deposits have no definite upper boundary, as would be expected if they were lacustrine in origin.

The mantle of uniform loesslike silt on top of the bedrock hills is here considered to be primary loess, windblown and derived from the braided streams and broad plains, because (1) it occurs as a surficial mantle; (2) it is lithologically independent of the underlying material; (3) the fine silt is stratified indistinctly or not at all, except in retransported materials; (4) it is associated with sand dunes in a broad wind-blown area; (5) it contains fossils of land animals; (6) its sorting and texture on hilltops is similar to that of loess and windblown dust in many other 
places in the world; and (7) its grains are angular and relatively unweathered. The thick mantle of poorly to wellstratified loesslike silt on the lower slopes and along the bottoms of major river valleys, however, is retransported loess. It has been transported from a few meters to hundreds if not thousands of meters down slopes, primarily by processes involving water; consequently, it has become interlayered with sand or with gravel. Almost all of the loesslike silt in the southern part of the Qinghai-Xizang (Tibet) Plateau is retransported loess.

\section{摘要}

在中国西南部的青藏高原上广泛分布者棕黄色的黄土状堆积， 其时代可能属晚第四纪。它们大部分被重新投运，堆积于洼地、坡 肺以及大多数洪积扇上, 并与洪积扇的砂砾互层。这些黄土状堆积 在沟谷低所地的农田及被切割的沟谷充填物陡壁上出客清哳。在低 山丘的顶部, 它们则以原生风成黄土的形式出现, 其物质可能来源 于无植被盖的洪积扇或北部的千湖泊。

原生黄土的库度在低山丘的项部和坡上部达 $6 \mathrm{~m}$, 在坡版达 $10 \mathrm{~m}$ 。 最度者位于河流附近的沟谷底部, 达 $15 \mathrm{~m}$, 从而形成直立的陡壁。

原生黄土的矿物及粒度组成较为均一, 而次生黄土的粒度变化 较大，从粘土质到砂质甚至砾质都有，具体质地取决于物源的远近、 被掓运的距离及由流水作用所混入的其它沉积物的多少。这些黄土 呈块状，被侵蚛后形成陡壁，一般无层理或节理，但堆积于坡脚及 汋谷底部的再投运黄土则具不同清析度的层理。

这些黄土中的第四纪化石较少，有孢粉、介形虫、腹足类及哺 乳动物牙齿和骨胳，反映了在千令的坏境中有少是湿地和沼评。

近年来，对这些黄土状堆积的成因有不同看法，有人认为是就 地风化形成，也有人认为与湖积、冲积或风的作用有关。湖积或冲 积假说最早形成于70年代晩期, 到80年代首次提出了风成说。

早在 30 年代，这些黄土状土被认为是由下伏岩石经寒冻作用破 碎而形成。但这种解释难于确立, 因为它们庶度较大, 且与下伏地 层没有化学、矿物及粒度组成上的联系。

多数人认为, 这些原层的黄土状土, 尤其是堆积于沟谷底部者 与湖泊过程有关。但这种可能性似乎较小，因为我们既没有在附近 发现古岸线、波䖯岸或三角洲，也没有在这些黄土状土中发现泥裂、 波菠或与湖泊有关的层理。从站上含严上看也不象是湖相成因的。 此外，这套堆积中也没有湖相沉积中所具有的清哳上界。

我们认为, 以披盖形式发育于基岩丘顶部的均质的黄土状上是 原生风成黄土，其物质来源于游荡性河道或冲积平原，因为：(1) 它们认披盖的形式出现；（2）岩性与下伏地层无联系；（3）除再投 运者外, 大部分无层理或层理不清晰; (4) 和风成砂丘相伴生; (5) 所含化石为陆生动物化石; (6) 其分选性及质地与世界各地的黄土 类似；（7）其中矿物颖粒呈校角状，且风化很弱。而发育于坡脚和 河谷底部的具不同清哳度层理者是主要经流水再掓运的黄土, 投运 距离可从几米到几百米，以玫于其中含有砂砾层。在青藏高原南部， 几乎所有的黄土状土都是再投运的黄土。

\section{INTRODUCTION}

China is well known for some of the most extensive accumulations of loess in the world. Loess is one of the most extensive Quaternary deposits of the country, covering about $1,000,000 \mathrm{~km}^{2}$, or about 10 percent of China. Although most of the loess is in north-central China, it is also widespread in the northwestern and northeastern parts of the country (fig. 1). The earliest known description of Chinese loess appears to be more than 2,300 years old (Liu and others, 1964, p. 10); the earliest known record of the ubiquitous dust storms from the deserts was a so-called "dust rain" that occurred in 1150 B.C. and is documented in the historical book, Zhu Shu, Ji Nian (Chronicles Recorded on Bamboo Slips) (see Liu, 1981). Characteristics of Chinese loess and diverse ideas of its origin have been known outside of China since the explorations of Raphael Pumpelly (1867, 1879), Baron Ferdinand Paul Wilhelm freiherrn von Richthofen (1877, 1882, 1886), and Bailey Willis, Eliot Blackwelder and R.H. Sargent (1907).

However, even on recent maps showing loess distribution in China (Wang and Zhang, 1980; Liu and Yuan, 1982; Wang and Song, 1983; Liu and Ding, 1984; Liu and others, 1985, 1988; Liu, 1981, 1991), no loess is shown on the Qinghai-Xizang (Tibet) Plateau on a recent map of China (fig. 1). Lack of knowledge of detailed geologic reports of the plateau can be attributed to the geographical and political remoteness of this region, often called the "Roof of the World," that is rimmed by even higher mountains. This unique environment has an isolated civilization that was relatively unchanged until the 1951 occupation by Chinese from the east. Since the 1950 's, China has organized seven multidisciplinary integrated surveys to the Qinghai-Xizang (Tibet) Plateau. More than 50 disciplines, represented by more than 1,600 scientists and technicians from Academia Sinica have made very informative studies, and 32 volumes of reports have already been published. Yet much, if not most, of these efforts were unknown outside of China until the landmark international symposium on the geological and ecological studies of the Qinghai-Xizang (Tibet) Plateau was held in China in 1980 (Liu, 1981; Péwé, 1980a, b, 1981; Reiter and Reiter, 1981; and Sengör, 1981). Academia Sinica arranged this historic symposium that included a field study trip to the Qinghai-Xizang (Tibet) Plateau. Of 79 scientists from 18 countries who initially met with 240 Chinese scientists in Beijing, 66 participated in a stimulating 2-week trip through the southern part of the plateau and traveled $1,000 \mathrm{~km}$ to Nepal.

This field trip followed and crossed broad, vegetation-free flood plains and sand dunes on the valley bottoms and low hillsides that are quite striking in the southern part of the Qinghai-Xizang (Tibet) Plateau. It soon became apparent to Liu and Péwé that the widespread yellowish loesslike sediment was undoubtedly retransported loess because (1) it covers some alluvial fans and is interbedded with the sand and gravel of the fans, (2) it is well exposed in agricultural fields in the valleys, and (3) it forms thick steep-walled terrace scarps in dissected valley fill. Winds probably blew it there originally from the sand and silt bars of the broad rivers and perhaps from dry lake basins to the north. The geologic guidebook of the area (Academia Sinica, 1980) does not mention loess but does mention thick lacustrine deposits. 
We saw small valleys as wide as $1 \mathrm{~km}$ that had slowly filled to a thickness of $30 \mathrm{~m}$ or more with retransported loess. These valley fills had subsequently been dissected by streams rejuvenated by uplift, probably in Holocene time. Slow aggradation and interlayering of retransported loess with some fluvial sand and locally fine gravel has created nearly flat surfaces on the old valley floors that now stand above valley flood plains as buttes or mesas, 15 to $30 \mathrm{~m}$ high, with almost vertical walls. These landforms are common at Xigaze and also at Turpan, $1,500 \mathrm{~km}$ to the north, for example.
As silt accumulated locally in valley bottoms, remains of the extant flora and fauna were incorporated. Sandy primary loess accumulated on low hills next to the rivers and is interfingered downslope with coarse sediments. Péwé collected sediment samples and associated fossils in Yangbajain Basin north of Lhasa, in the vicinity of Lhasa, and southwestward through major valleys, high passes, and mountain ranges to Gyangze on the middle Nyang Qu and to Xigaze near the junction of the Nyang Qu and the Yarlung Zangbo (fig. 3, table 1). Detailed collections and observations were made near Xigaze. Sediments, topography, and geomorphology

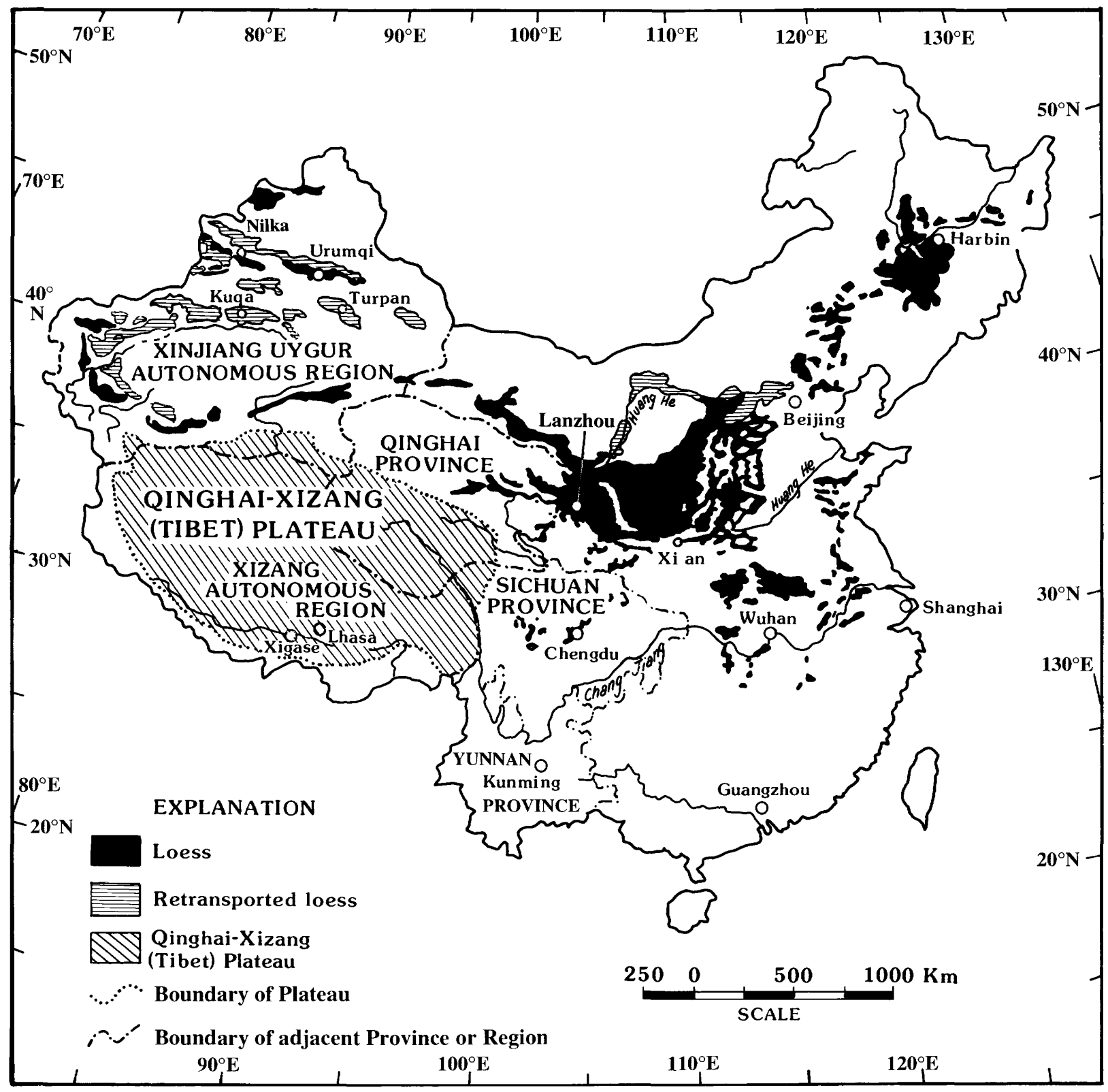

Figure 1. Distribution of loess in China and location of Qinghai-Xizang (Tibet) Plateau. Loess data from Liu (1981); Liu and others (1985). Retransported loess data from Wang and Song (1983), Mu Guijin (oral commun, 1986), and Péwé (1987). From Péwé and others (1987) and reproduced with permission of China Ocean Press. 
were studied along the wide Yarlung Zangbo for about $60 \mathrm{~km}$ downstream from Xigaze and then westward to Lhaze and Tingri, where loesslike silt was seen. From Tingri, data were collected south to the Nepal-China border. Péwé left the group at Zham, exiting to Nepal. Liu and Li collected more samples at Xigaze and near Lhasa on their return trip to Beijing. For comparison with silt from the Qinghai-Xizang (Tibet) Plateau, typical loess deposits were examined and sampled by Péwé near Heidelberg, Germany (near the site where the term "loess" originated), and were analyzed in the same laboratory as samples from the plateau. To more fully understand the characteristics and distribution of the widespread retransported loess in China, Péwé also examined and collected samples of such deposits at Harbin (fig. 1) in northeast China in 1984 and 1986 and in Xinjiang Uygur Autonomous Region (fig. 1) from Turpan to Kuqa on the south side of the Tian Shan in 1986 (Péwé, 1987) and near Ürümqi in 1982. $\mathrm{Li}$ also made observations of the loesslike silt deposits in the southern part of the Qinghai-Xizang (Tibet) Plateau during the summers of 1974 and 1975.

In the summer of 1991, Péwé was a leader on a geologic field study trip of the International Union for Quaternary Research (INQUA) XIII International Congress, from Lanzhou across the Qinghai-Xizang (Tibet) Plateau through Qinghai Province and then south to Lhasa and to Nepal (fig. 1). The first week permitted observation of loess 1 to $2 \mathrm{~m}$ thick in the valleys of the northern part of the plateau. The last 5 days from Lhasa to the Himalayas allowed a reexamination of retransported loess along the same route of the 1980 geologic trip of Péwé, Liu, and Li.

Detailed examination was made of retransported loess by the international group of loess scientists at the south side of Xigaze, site of detailed observations and sample collections in 1980 .

After discussions and collecting of silt and fossils by participants, it was the belief of the visiting loess experts that the loesslike silt was typical retransported loess.

\section{ACKNOWLEDGMENTS}

The authors deeply appreciate the cooperation and aid of many persons in several countries who made this study possible. Officials of the Academia Sinica Organizing Committee of the Symposium on the Qinghai-Xizang (Tibet) Plateau (Liu, 1981) and the government of the Xizang Autonomous Region provided the opportunity for Péwé, Liu, and Li to visit the area in 1980 and make the study. The U.S. National Academy of Sciences funded part of Péwé's 1980 visit to China while he was Chairman of the U.S. Organizing Committee of the Fourth International Conference on Permafrost. Part of Péwé's participation in the study was funded by a travel grant (No. EAR 8013759) from the National Science Foundation of the United States and a travel grant from Arizona State University.
Granulometric analyses of samples 1 to 10 and all mineralogical and chemical analyses were made at Exploration and Production Research of the Cities Service Company, Tulsa, Okla., under the direction of Roger M. Slatt, then Stratigraphy Research Manager. Granulometric analyses of samples 11 to 17 were made at the Geological Institute of the Academia Sinica, Beijing under the supervision of Liu Tungsheng. All analyses of loess sample 20 (tables 1-3), which was collected in 1973 near Beijing by Roger J.E. Brown, were made at the Centre de Geomorphologie, Caen, France, under the direction of André Journaux.

At the 15-m-high exposure of loesslike silt south of Xigaze, the authors were aided in collecting fossils by the late Anders Martinsson, University of Uppsala, Sweden, by Bruno Messerli, University of Bern, Switzerland, by Jack Ives, University of Colorado, U.S.A., and by Chinese and Tibetan assistants.

Fossils from the exposure near Xigaze were identified by experts in China and the United States. Li Yuanfang and Huang Cixuan, Geographical Institute, Beijing, Academia Sinica, examined the ostracodes and pollen, respectively. Charles E. Schweger, University of Alberta, Canada, supplied additional information on the interpretation of the pollen data. A.H. Clarke, Associate Curator of the Mollusca, U.S. Smithsonian Institution, Washington, D.C., identified the freshwater gastropods; and S.L. Olson, Division of Birds, U.S. National Museum of Natural History, Smithsonian Institution, Washington, D.C., identified the bird remains. Michael Carleton, Division of Mammals of the U.S. National Museum of Natural History identified the mammal bones. Radiocarbon analyses of gastropods collected by Péwé were made at the Smithsonian Institution Radiation Biology Laboratory, Washington, D.C., then under the direction of Dr. Robert Stuckenrath, and radiocarbon analyses of gastropods collected by Martinsson were made at the Institute of Physics, University of Uppsala, Sweden, under the direction of Ingred U. Olsson. Redford Ju helped translate some of the Chinese literature.

$\mathrm{Mu}$ Guijin, geologist with the Xinjiang Institute of Geography, Academia Sinica, Ürümqi, Xinjiang Uygur Autonomous Region, was especially valuable in researching some of the Chinese literature on the Quaternary geology of the Qinghai-Xizang (Tibet) Plateau, calculating statistical parameters of the sediment samples, drafting some illustrations, compiling tables 2 and 3, and making granulometric analyses of Chinese sediment samples 18 and 19 while a visiting scholar at Arizona State University, 1984-85. Hu Chang Kang kindly arranged meetings in 1986 between Huang Wanpo (of the Institute of Vertebrate Paleontology and Paleoanthropology, Academia Sinica) and Péwé to discuss and examine the finds of vertebrate fossils in southern part of the Qinghai-Xizang (Tibet) Plateau. Wang Shuji (Director, Xinjiang Institute of Geography, Academia Sinica, Ürümqi) led Péwé on a 10-day field excursion in 1986 to examine retransported loess, gobi, 
and sand dunes in the Turpan Depression, Tarim Basin, and Ürümqi area of the Xinjiang Uygur Autonomous Region.

The authors appreciate the time given to field discussions of the origin of loess deposits in Xizang Autonomous Region by participants of the 1991 field trip of the International Union for Quaternary Research (INQUA) to the plateau, especially N.W. Rutter, University of Alberta, Canada, and G.J. Kukla, Columbia University, U.S.A.

Special appreciation is extended to Margaret Fegtly Nichols, Tempe, Arizona, U.S.A., for aiding in literature search about exploration of southern Tibet by Europeans in the early part of the 20th Century; and to Susan Mary Selkirk, graphic artist, Arizona State University, for preparing most of the graphics in the report.

Helpful suggestions of the following people who reviewed all of the report are greatly appreciated: $\mathrm{Mu}$ Guijin, of the Xinjiang Institute of Geography, Academia Sinica, Ürümqi, China; George Gryc and Oscar J. Ferrians, Jr., of the U.S. Geological Survey; and Richard D. Reger of the Alaska Division of Geological and Geophysical Surveys, Fairbanks, Alaska, all of whom observed loess in eastern, central, and western (Lanzhou) China in 1984.

\section{PHYSICAL SETTING}

\section{PHYSIOGRAPHY AND GENERAL GEOLOGY}

The Qinghai-Xizang (Tibet) Plateau is a unique landform of the Earth, averaging more than $4,000 \mathrm{~m}$ in elevation and covering an area of $2,400,000 \mathrm{~km}^{2}$, almost one-quarter of China's territory. It is bounded by mountains on all sides: the Kunlun Shan on the north; the towering, glacier-clad Himalayas on the south; the Karakorum Shan on the west; and the Hengduan Shan on the east (fig. 2). Most of the plateau lies in the Xizang Autonomous Region $\left(1,200,000 \mathrm{~km}^{2}\right)$; one-quarter is in the Qinghai Province, and the rest is in adjacent provinces (fig. 1). The former political entity of Tibet coincides territorially with the present Xizang Autonomous Region, which constitutes part of southwestern People's Republic of China.

Most of the plateau is an arid, almost treeless, windswept landscape at elevations of 3,500 to $7,200 \mathrm{~m}$. The complex of mountain ranges, broad valleys, and rocky plains is liberally strewn with shrinking lakes (Chen, 1986; Chinese Academy of Sciences, 1974, p. 80) of varying degrees of salinity containing as many as 46 kinds of salt minerals (Gao and $\mathrm{Li}, 1981$ ). The area is sparsely occupied by Tibetan nomads. The populous cultivated valleys in the south and southeast part of the plateau lie below 4,000 m elevation. At the lower elevations and in local areas of alluvium and retransported loess, slightly greater precipitation permits a limited amount of agriculture.
The Yarlung Zangbo valley in the south (fig. 3), together with its tributary valleys, is the heartland of Xizang Autonomous Region. For centuries it was part of the major ancient trade routes from Europe, India, China, and central Asia. Lhasa, the capitol, formerly was also the residence (frontispiece) of the Dalai Lama, who headed the religious civil government of Tibet. Major centers of population, other than Lhasa, are Xigaze and Gyangze southwest of Lhasa (fig. 3).

The southern part of the plateau south of the Gangdese Shan (fig. 2) and Nyainqentanglha Shan (fig. 3), includes the Yarlung Zangbo, Pum Qu and Nyang Qu systems. Many major lakes exist, some without outlets (fig. 2). This part of the plateau is bisected from east to west by the Yarlung Zangbo valley; (fig. 3), which is dotted with as many as 600 geothermal fields, such as the one in figure 4.

It has long been believed that the great elevation of the Qinghai-Xizang (Tibet) Plateau and the Himalayas is the result of shifting continental plates, as the northward-moving Indian plate from the south collides with and slides under the Eurasian plate to the north (Argand, 1924; Molnar, 1989). An ophiolite belt along the Yarlung Zangbo, 3 to $15 \mathrm{~km}$ wide, separates the two plates along this major tectonic suture (Academia Sinica, 1980; Kidd and others, 1988). To the north the continental crust is about $70 \mathrm{~km}$ thick in what is termed the Gangdese-Nyainqentanglha Tectonic Zone (cover, fig. 3), or Northern Xizang Structural Area (Chang and Pan, 1981, fig. 2); to the south the crust is about $50 \mathrm{~km}$ thick in what is called the northern part of the Himalayan Tectonic Zone (fig. 3). Uplift began in early Miocene time (Sorkhabi and Stump, 1993), was strongest near the end of the Pliocene, and extended into the Pleistocene. For the past 100,000 years, the average rate of uplift has been about $10 \mathrm{~mm}$ per year (Liu, 1981, p. xix). Mt. Everest (Qomolangma Feng), the highest mountain in the world $(8,848 \mathrm{~m})$, straddles the crest of the Himalayas on the southern boundary of the Xizang Autonomous Region (figs. 2, 3).

North of the ophiolite belt, Cretaceous andesites, shales, and sandy conglomerates are more than $400 \mathrm{~m}$ thick. North of these rocks is a large, east-west belt of granodiorite and granite; the granite intrudes Triassic and Jurassic sandstones, shales and limestones. South of the Yarlung Zangbo, a wide belt of Triassic clastic rocks is predominantly turbidites. Near Xigaze an extensive eastwest belt of predominantly medial to distal Cretaceous turbidites includes some black shales and limestones. The lower Lhasa He flows through a granitic belt of the Northern Xizang Structural Region (cover photograph) that is in local contact with Triassic and Jurassic clastic rocks or limestones. Small hills rise about $100 \mathrm{~m}$ above the valley floor near Lhasa, and the magnificent monastery and former home of the Dalai Lama, Potala Palace (frontispiece), is built on one of Jurassic clastic rocks and limestone.

Mountains on the plateau and rimming it host most of the nearly 30,000 glaciers of China (Shi and others, 


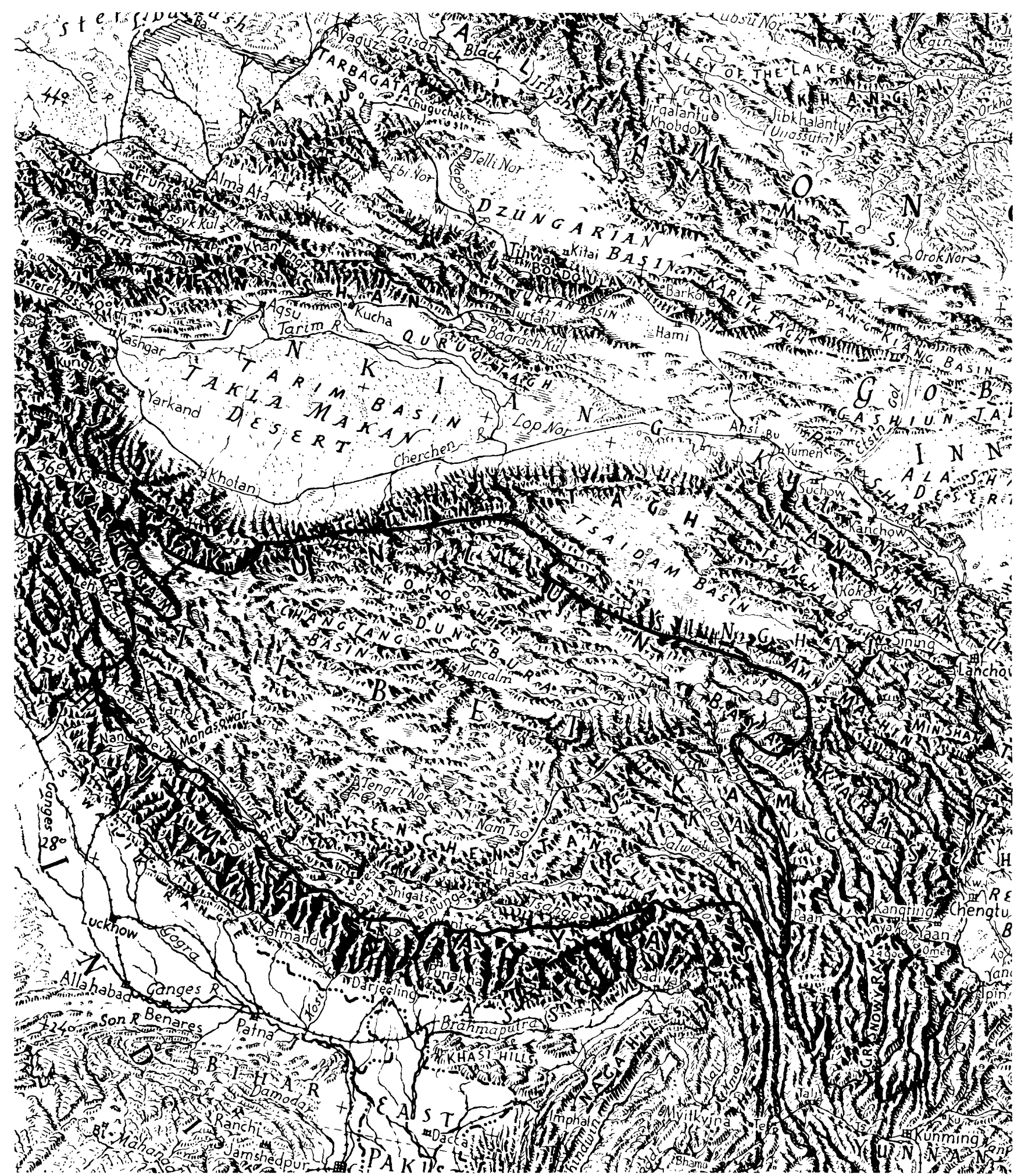

$\boldsymbol{A}$

Figure 2. Landform map $(A)$ and index map $(B)$ of western China showing location of Qinghai-Xizang (Tibet) Plateau and features of Xinjiang Uygur Autonomous Region, Xizang Autonomous Region, and parts of the Qinghai, Sichuan, and Gansu Provinces. Landform map is part of "Landforms of China," (copyright by Erwin Raisz, 1955, and reprinted with permission of Raisz Landform Maps, P.O. Box 773, Melrose, MA 02176).
Index map by S.M. Mayfield. Names on landform map are English equivalents of those in use when map was prepared. Names on index map include many used in this report. (U.S. Board on Geographic Names approved "Qing Zang Gaoyuan" as the name for the Tibet Plateau; however, the term "Qinghai-Xizang (Tibet) Plateau" is most widely used in international scientific Englishlanguage publications and is used in this report.) 


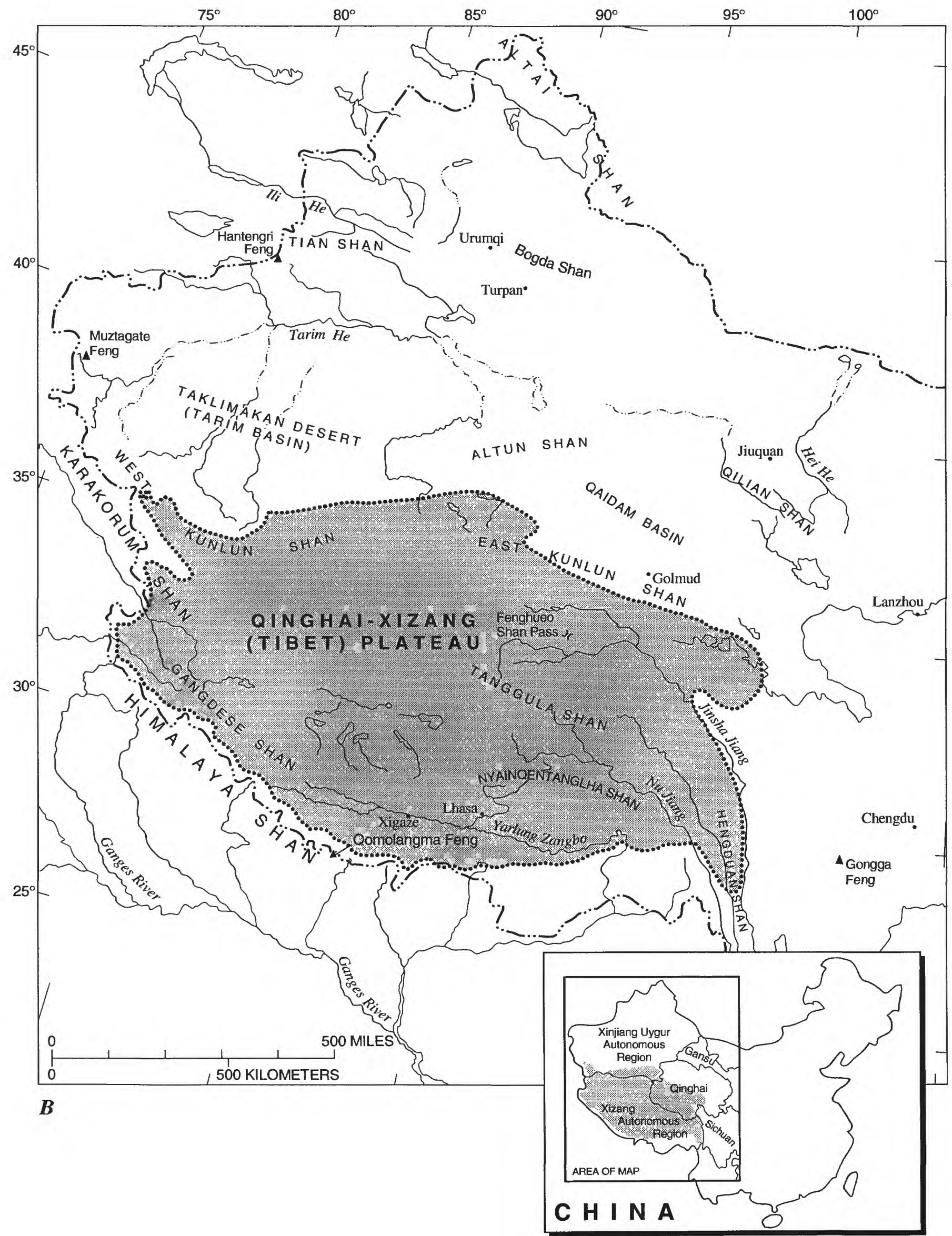




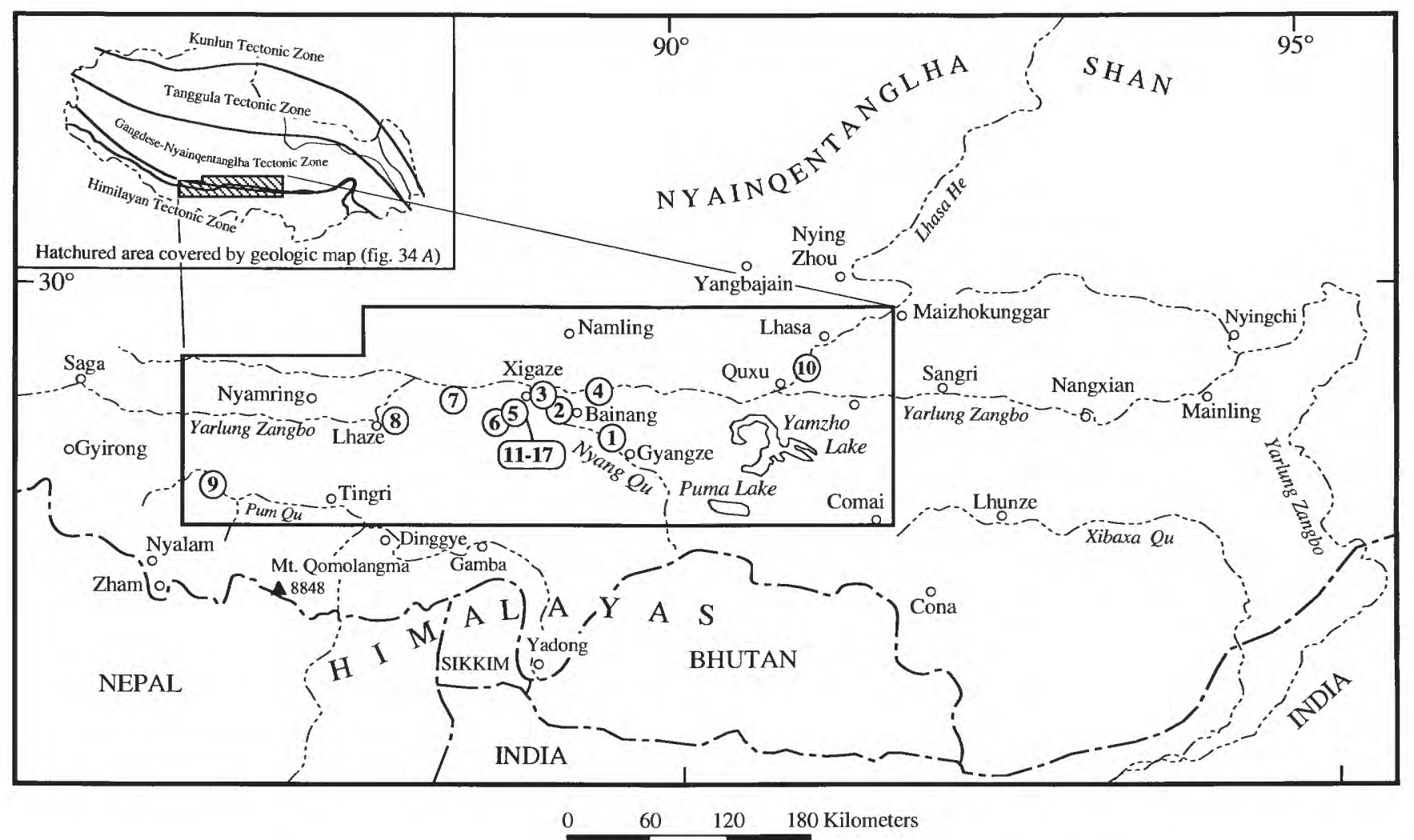

Figure 3. Index map of south-central Qinghai-Xizang (Tibet) Plateau, China. Circled numbers are locations of sediment samples (see table 1). Rectangle in upper left corner outlines the four major tectonic zones of the plateau (from Academia

1980; Shi and Li, 1980, 1981; Shi, 1988). About 83 percent of the area covered by modern glaciers in China is in this region (fig. 5). Most are small cirque glaciers and winding alpine glaciers, although a few are nearly $30 \mathrm{~km}$ long. The high elevation, topography, and particularly the climate of the plateau influence the development and distribution of these glaciers (Kuhle, 1986). Two main types of glaciers are present on the plateau: Continental glaciers in the cold, dry parts of the plateau, and maritime glaciers in the southeastern part of the plateau, where monsoon precipitation is high. The snow line ranges from about $4,400 \mathrm{~m}$ in the southeast to more than $6,200 \mathrm{~m}$ in the western part of the plateau (fig. 5). Snow-line variation is mainly due to the rapid decrease of precipitation in the higher mountains toward the inner parts of the plateau. The west-central part of the plateau receives the highest total solar radiation in China. Numerous mass-balance studies of glaciers have been made by Chinese scientists who found that solar radiation accounts for 80 to 90 percent of the heat sources in the majority of glaciers in the arid part of the plateau and decreases to about 60 percent in the humid southeastern plateau.

Natural vegetation of the southern part of the plateau is that of a montane shrubby steppe or locally an alpine
Sinica, 1980) superposed on an outline map of Xizang Autonomous Region, China. Center rectangle is area covered by geologic map (fig. 34A) and mineral distribution maps (figs. $34 B, C$ ).

steppe (Zheng and others, 1981) of the semiarid region. Most common species are Sopora moorcroftiana, Trikeraia haekeri, Aristida triseta, and Artemisia. Common associates are Astragalus strictus, Poa patens, and Androsace graminofolia (Yang and others, 1983; Li and others 1983). This region is essentially unforested except for species locally growing near streams. Agriculture has been introduced in the broad valley lowland near the major villages. Conditions are suitable for growing barley, wheat, potatoes, peas, turnips, and apples.

\section{CLIMATE}

The climate of the Qinghai-Xizang (Tibet) Plateau is mainly characterized by strong winds, cold temperatures, and aridity, especially in the high western and central parts (fig. 6). Except for the southern major valleys (figs. 2, 3), the mean annual air temperature is colder than $0^{\circ} \mathrm{C}$. On the higher plateau, the mean annual air temperature ranges from -6 to $-10^{\circ} \mathrm{C}$ (Academia Sinica, 1980). Some of the earliest temperature records reported in English from the high plateau are from Hedin (1903), who recorded $-32.5^{\circ} \mathrm{C}$ in January 1901. Climatic data have been collected since 


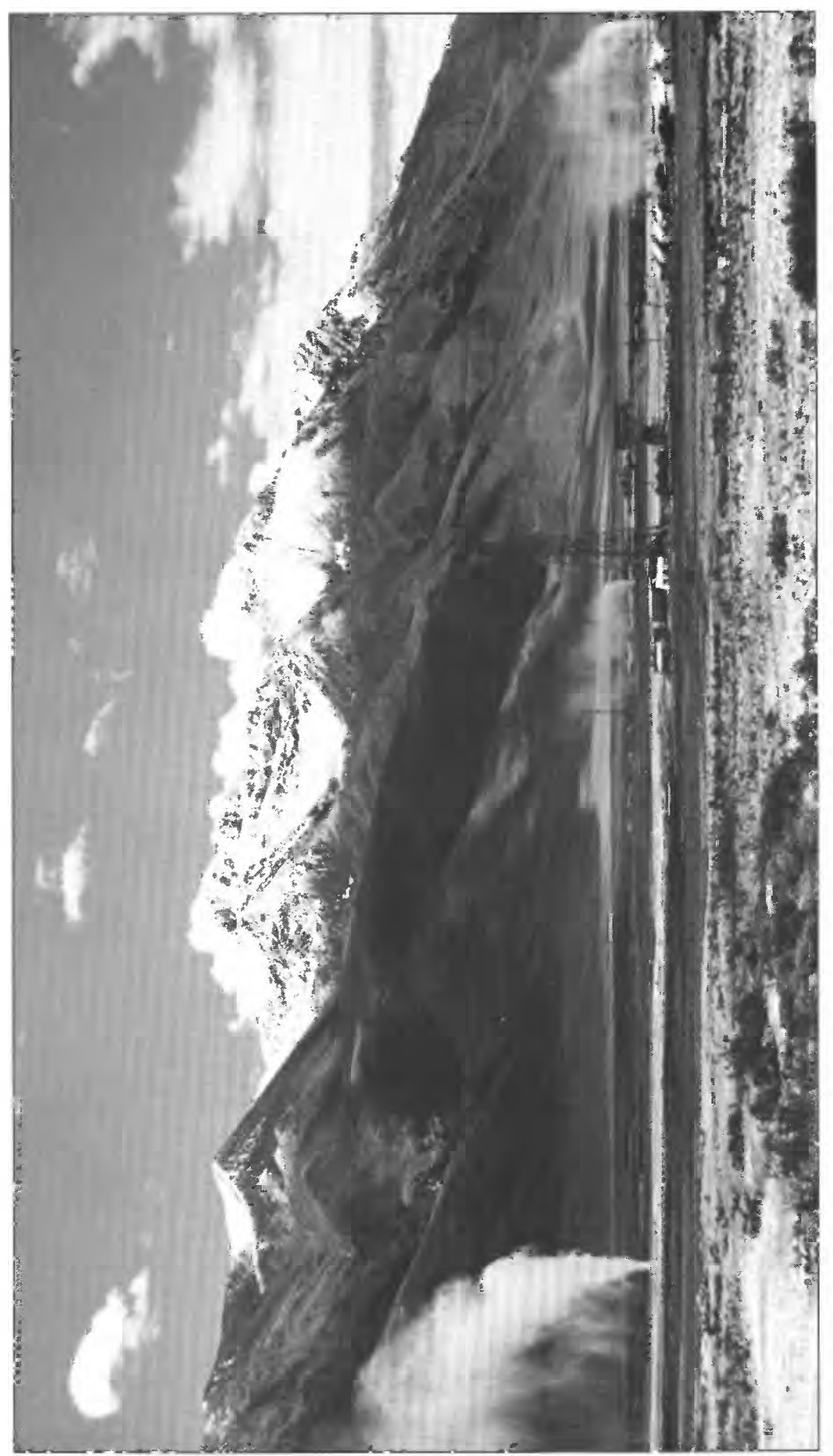

离主总 政

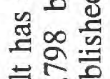
零完 光光芯

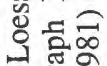
항 害莒

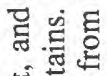
苛焉 证. 馬范

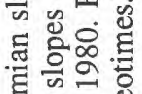
矛的号

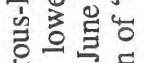
동.

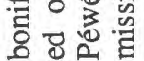

틀. 틀 छี

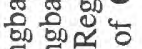

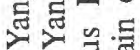
Ð용 㲅艺

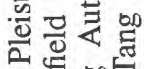
흠 ్ㅗㄹ 吾 胳 吕 ్ㅠ월

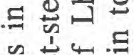

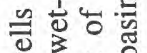
5 苟

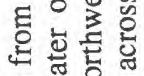

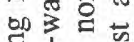
跣范 틀응유 诺 क 는

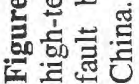


1957 along a road that runs northward from Lhasa to Qinghai Province (Xie, 1982). At Fenghueo Shan Pass (elevation $4,800 \mathrm{~m}$ ), about $500 \mathrm{~km}$ north of Lhasa (fig. 2), for example, the mean annual air temperature is $-6.6^{\circ} \mathrm{C}$ (Wang and French, 1994).
In the southern valleys, the mean air temperature during the warmest month ranges from 10 to $16^{\circ} \mathrm{C}$; during the coldest month (January) it is $-8^{\circ} \mathrm{C}$. Mean annual air temperature ranges from 3 to $8^{\circ} \mathrm{C}$. In Lhasa (elevation $3,658 \mathrm{~m}$ ) the mean annual air temperature is $7.5^{\circ} \mathrm{C}$; the average for June

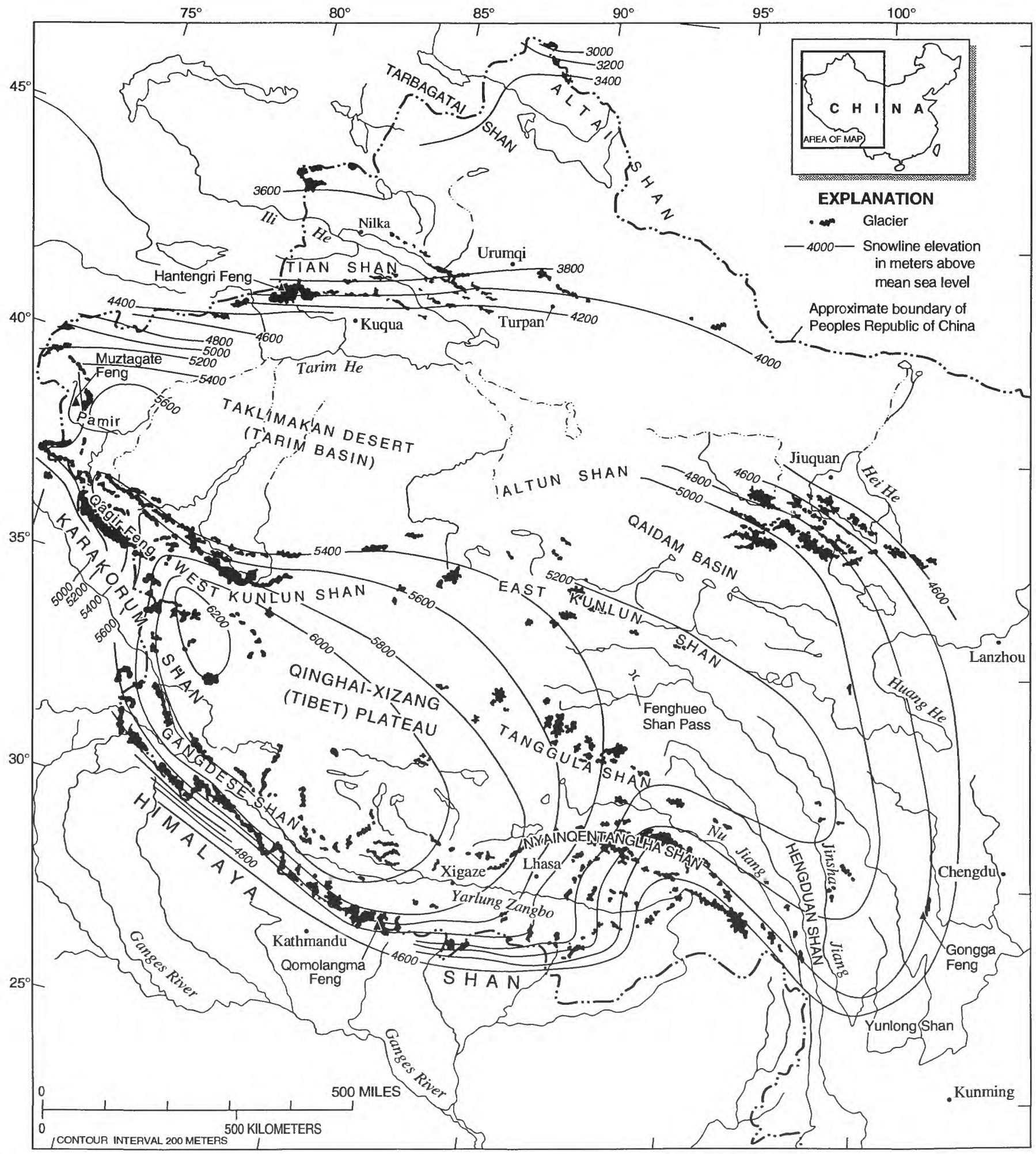

Figure 5. Distribution of existing glaciers and snow-line elevations in China (from Shi, 1980). 
is $15.5^{\circ} \mathrm{C}$ and for January is $-2.2^{\circ} \mathrm{C}$ (Academia Sinica, 1980 , p. 5). The frost-free season is 140 days. As one goes west, the climate becomes colder and drier. Mean annual air temperatures of Lhasa, Xigaze, and Tingri are $6.3^{\circ} \mathrm{C}, 4.8^{\circ} \mathrm{C}$, and $2.7^{\circ} \mathrm{C}$, respectively (figs. $7,8,9$ ).

The western part of the plateau is arid, and most of it receives little more than $100 \mathrm{~mm}$ of precipitation annually (fig. 6). The southern valleys are in the semiarid zone (250$500 \mathrm{~mm}$ precipitation), and the far east is humid. The dry season extends from October to May and the wet season from June to September. Mean annual precipitation in Lhasa, Xigaze, Gyangze, and Tingri is $445,431,288$, and $318 \mathrm{~mm}$ respectively (Academia Sinica, 1980) (figs. 7, 8, 9).

During winter, westerly winds prevail over the plateau, and from October through May there are clear skies and strong winds.

\section{PERMAFROST}

The Qinghai-Xizang (Tibet) Plateau lies in an area of widespread alpine permafrost. Permafrost, or perennially frozen ground, is a naturally occurring material that has been at a temperature of $0^{\circ} \mathrm{C}$ or colder continuously for 2 or more years. Permafrost is defined on the basis of temperature alone, notwithstanding the type of sediment or rock or the ice content. Most permafrost is consolidated by ice.

On the plateau, permafrost extends over an area of about $1,500,000 \mathrm{~km}^{2}$ and represents about 70 percent of all the permafrost in China (fig. 10; Tong, 1981; Cheng, 1983; Shi, 1988). Permafrost in the plateau exists at elevations higher than 4,100 to $4,200 \mathrm{~m}$ in the far north, where its minimum elevation rises by about $100 \mathrm{~m}$ per $1^{\circ}$ latitude (Cheng and Wang, 1982); to the south it starts at about 5,200 to $5,400 \mathrm{~m}$ elevation on the northern slopes of the Himalayas. Tong (1981) estimates that the ground temperature may be as cold as $-12^{\circ} \mathrm{C}$ at $6,000 \mathrm{~m}$ elevation in the northern part of the plateau and about $-7.4^{\circ} \mathrm{C}$ underlying the north slope of the Himalayas. The temperature of permafrost underlying most of the plateau is considerably warmer, and much of it is near $0^{\circ} \mathrm{C}$ near the topographical lower limit of permafrost.

Permafrost thickness is estimated to be about $400 \mathrm{~m}$ at an elevation of $6,000 \mathrm{~m}$ and not more than $130 \mathrm{~m}$ in the valleys or basins at lower elevations. Generally there is no permafrost beneath large rivers and lakes on the plateau. Ice wedges have not been recorded in the Qinghai-Xizang (Tibet) Plateau, and only one or two are known in northeast China (Péwé, 1986a, b). However, they may have been widespread in the perennially frozen ground of China in late Pleistocene time, as indicated by the presence of ice-wedge casts (Lanzhou Institute of Glaciology and Cryopedology, 1983; Sun and Li, 1986; Cheng and Liang, 1987).

A few pingos (large, ice-cored frost mounds in permafrost; Wang and Yao, 1981; Zheng and Jiao, 1991) and a multitude of high-altitude periglacial phenomena (Kuhle, 1985) exist on the plateau. Palsas (elliptical frost mounds in peat in permafrost) reported in 1980 at an elevation of

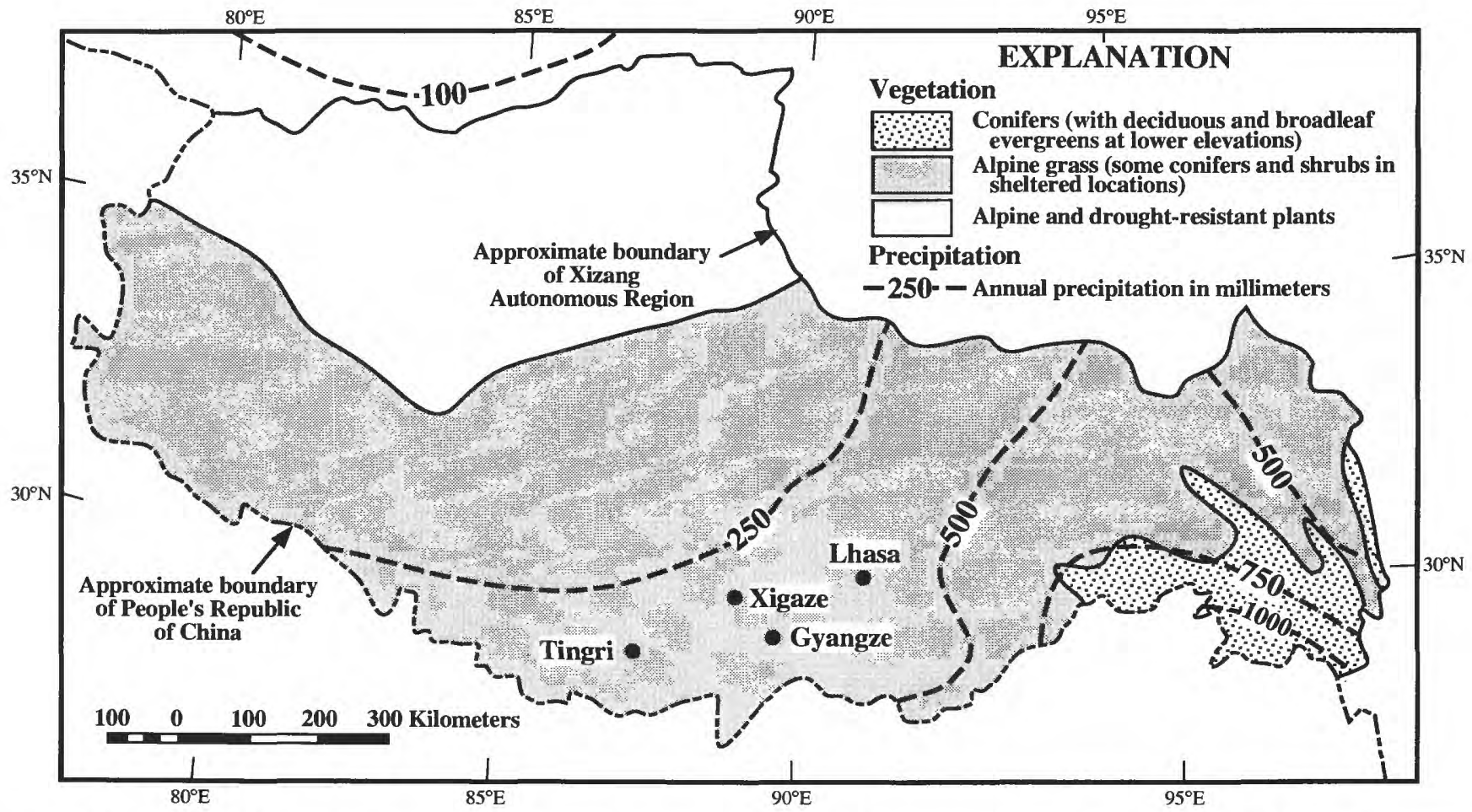

Figure 6. Generalized precipitation and natural vegetation map of Xizang Autonomous Region, China. Modified from Pradyumna (1976) and U.S. Government Printing Office (1971). 
about 5,000 m above sea level southeast of Gyaco La Pass in the southern part of Xizang Autonomous Region (Péwé, 1980a, b, 1981) are now thought to be frost blisters (low frost mounds in seasonal frost) (fig. 11). Because of the rigorous climate, perennially frozen ground and seasonally frozen ground are widespread, and a high number of freeze/thaw cycles per year favors mechanical breakdown of the rocks (Huang and others, 1981).
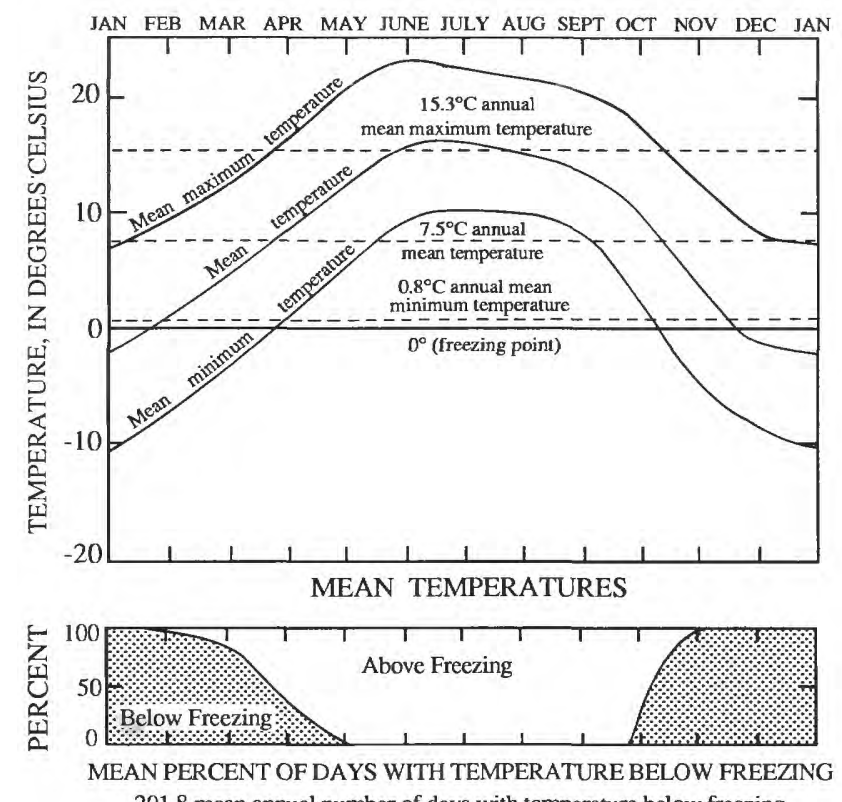
201.8 mean annual number of days with temperature below freezing
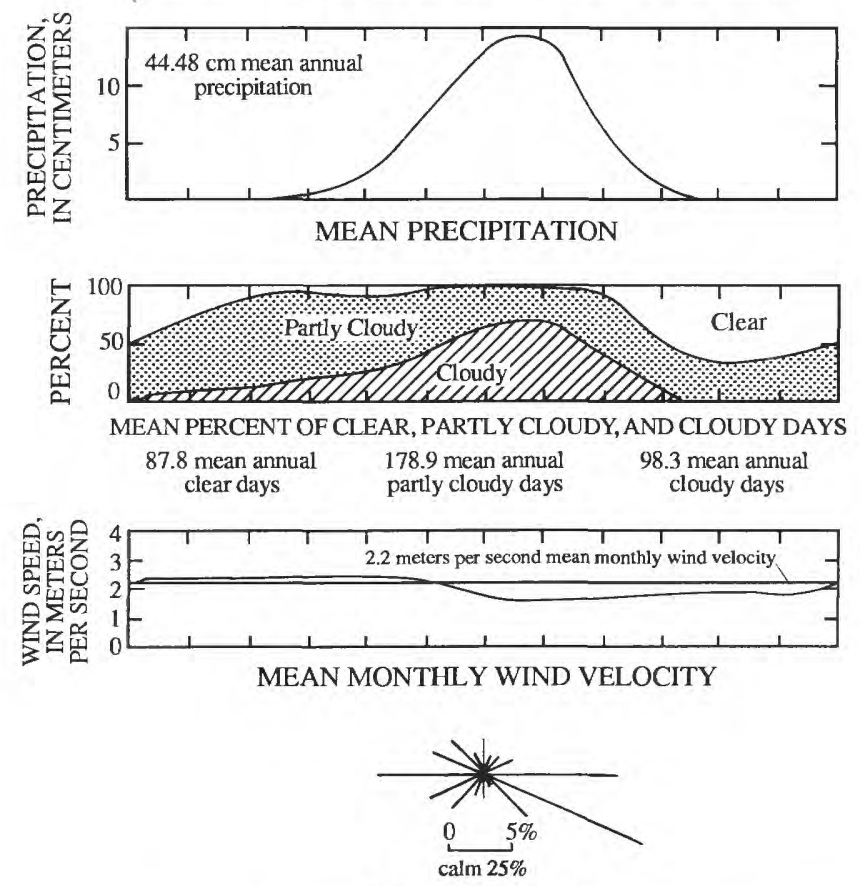

Lhasa (1951-1980)

MEAN ANNUAL FREQUENCY OF WIND DIRECTION

Figure 7. Climatic data for Lhasa, Xizang Autonomous Region, China (1951-1980). From Meteorological Bureau, Xizang Autonomous Region (1983).

\section{GEOMORPHOLOGY}

The geomorphology of the broad, flat-floored valleys (fig. 12) and the adjacent slopes (Lhalungpa, 1983, p. 128129 ) is of interest to this study. These areas exhibit sand dunes, sharply trenched terraces, and vertical silt cliffs. All the major rivers and many of the minor rivers in the southern part of the plateau seem to be braided and have
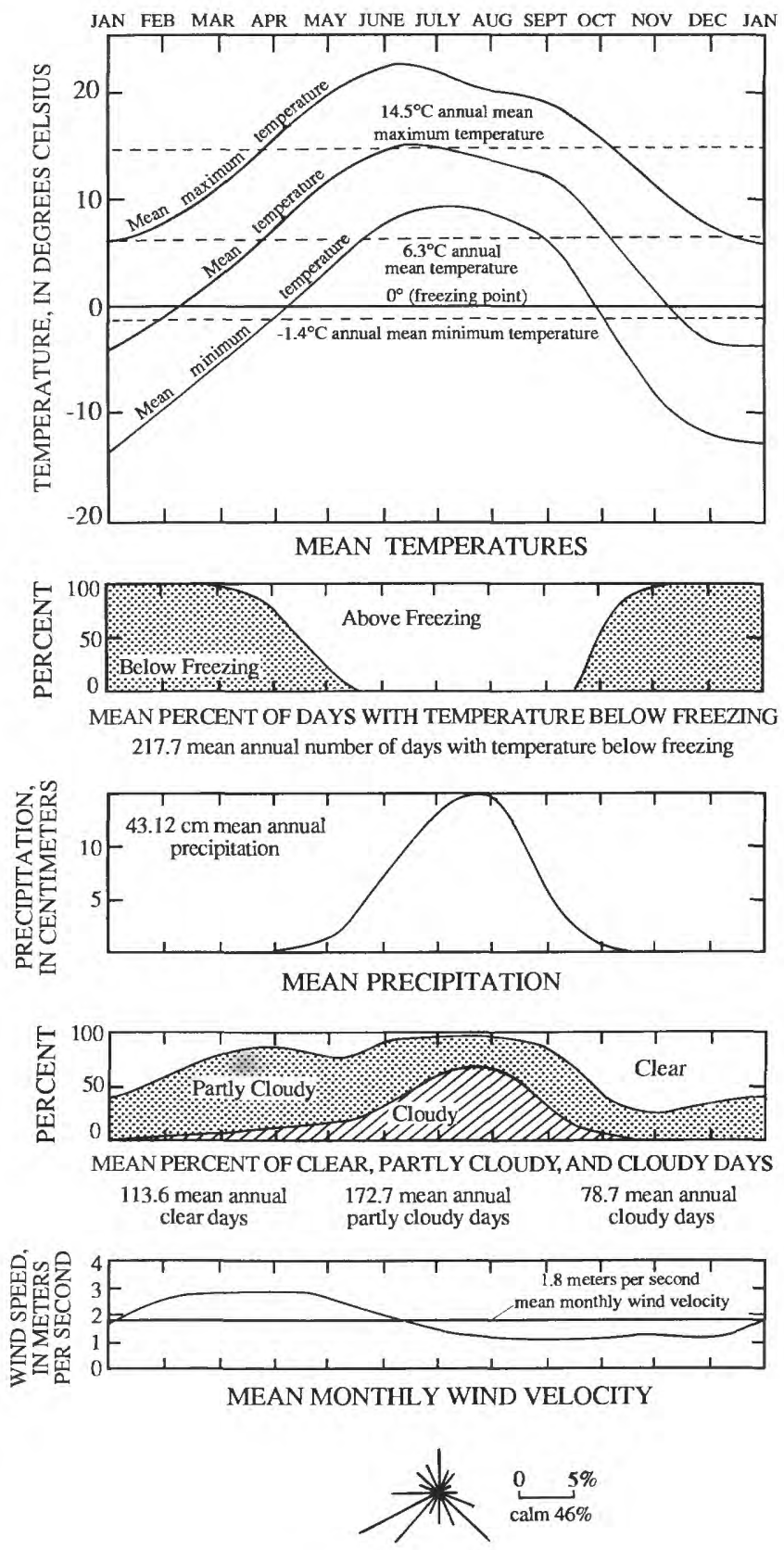

Xigaze (1955-1980)

MEAN ANNUAL FREQUENCY OF WIND DIRECTION

Figure 8. Climatic data for Xigaze, Xizang Autonomous Region, China (1955-1980). From Meteorological Bureau, Xizang Autonomous Region (1983). 
almost vegetation-free flood plains (cover, fig. 13). The Yarlung Zangbo in the vicinity of Xigaze is a heavily braided stream 8 to $10 \mathrm{~km}$ wide (Academia Sinica, 1980, p. 11). Large, low-angle alluvial fans form where major tributaries enter the wide valleys (fig. 14). Broad alluvial basins exist at Xigaze, Gyangze, Lhaze, Lhasa, Tingri, and many other places.
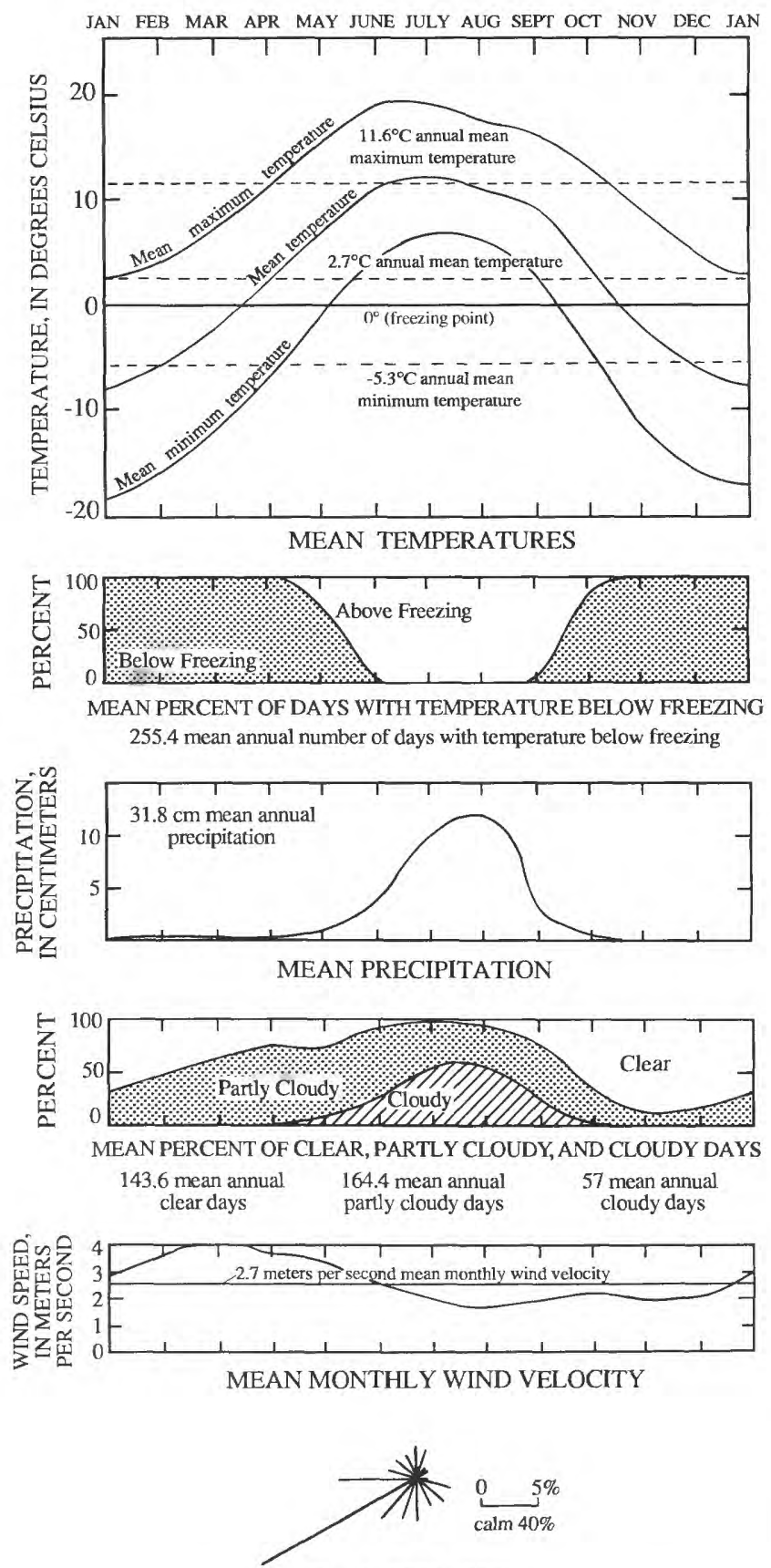

Tingri (1970-1980)

MEAN ANNUAL FREQUENCY OF WIND DIRECTION

Figure 9. Climatic data for Tingri, Xizang Autonomous Region, China (1970-1980). From Meteorological Bureau, Xizang Autonomous Region (1983).
Striking, active sand dunes and sand stringers have long been recorded in the broad valleys of the southern and central plateau (Rawling, 1905, p. 238). They are common on flood plains and on lower slopes of the bounding mountains (fig. 15) (Reiter and Reiter, 1981; Yang and others, 1981, p. 1756; Zhao and others, 1976, p. 6; Wang and Li, 1983, p. 4-5; Kreig and others, 1986; Wang and Fan, 1987). Most of them are conventional blow-out dunes or climbing dunes (cover, fig. 16), although an area of excellent barchan dune development was noted in the upper reaches of the Pum $\mathrm{Qu}$ valley near Tingri.

Lower slopes of foothills are characterized by fans of silt or fans of silt layers interbedded with sand or gravel layers that include silt. Most of the silt is well sorted, some of it is mixed with sand and gravel, and most is mineralogically different from the upslope bedrock. These fans are ubiquitously trenched by steep-walled V-shaped gullies (fig. 17), that radiate outward from the top of the fan and extend to the toe. These gullies were cut by streams in the easily erodible silt. At the village of Tingri (fig. 3), a gullied, low-angle fan of retransported loess sits at the base of a sharp-peaked hill of tilted sediments (fig. 18A). Because this site is along the road used by persons traveling south to Mt. Everest (Qomolangma Feng), numerous photographs show changing construction on the silt fan and at the adjoining Tibetan monastery (for example, fig. 18B) (Harvard, 1984, p. 77). Liu and Prof. Zhang Ronsu examined the sediments of the fan during the Academia Sinica scientific expedition to the Qinghai-Xizang (Tibet) Plateau of 1966-67, of which Liu was the leader. Zhang (now senior staff member at International Center for Integrated Mountain Development, Kathmandu, Nepal) observed then that the fan was a loesslike deposit. In 1980 , it was noted that small storage caves had been excavated in the loess, and, because of the ease in excavating loess, part of the fan was planed off in steps to make flat construction sites for more buildings (fig. 18A).

Locally, the distal parts of the silt fans have been eroded to form vertical cliffs as much as $15 \mathrm{~m}$ high. Like loess cliffs in central China, the Mississippi River valley and central Alaska, U.S.A., France, and elsewhere, these vertical silt cliffs in the southern plateau apparently stand for many years. The stability of these cliffs may be attributed to the angularity of the silt grains and to the strengthening effects of accretionary rods and tubes from earlier vegetation roots. Such cliffs are common south of Xigaze where they form the terrace scarps along the Nyang Qu (fig. 28).

The loesslike silt that water has transported from slopes to valley bottoms forms excellent agricultural land that locally supports large farms. The loesslike silt has been used to make bricks (fig. 19) for thousands of years, and some brick walls are still preserved in interesting archeological remnants (fig. 20) that remain along the busy trade routes of the past. 
Figure 10. Distribution of permafrost and seasonally frozen ground in China. Map from Lanzhou Institute of Glaciology and Cryopedology (1983) and published with their permission.

Figure 11. Eroded remnant of frost blister exposing part of an ice core in shallow drainage way, elevation 4,900 m, near Gyaco La Pass, near south border of Xizang Autonomous Region, China. Meter bar shows scale. Photograph 4583 by Troy L. Péwé, June 11, 1980; reprinted from Péwé (1981) and published with permission of "Geotimes."

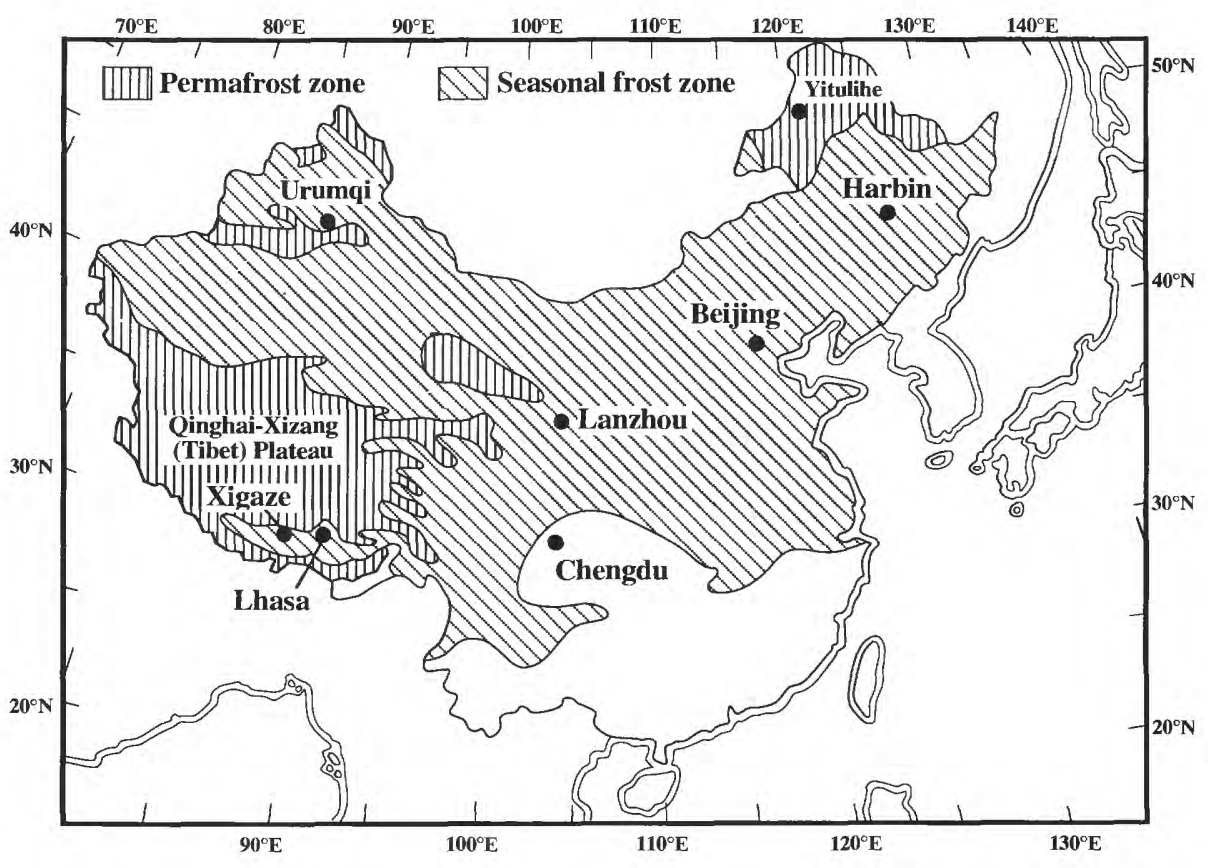

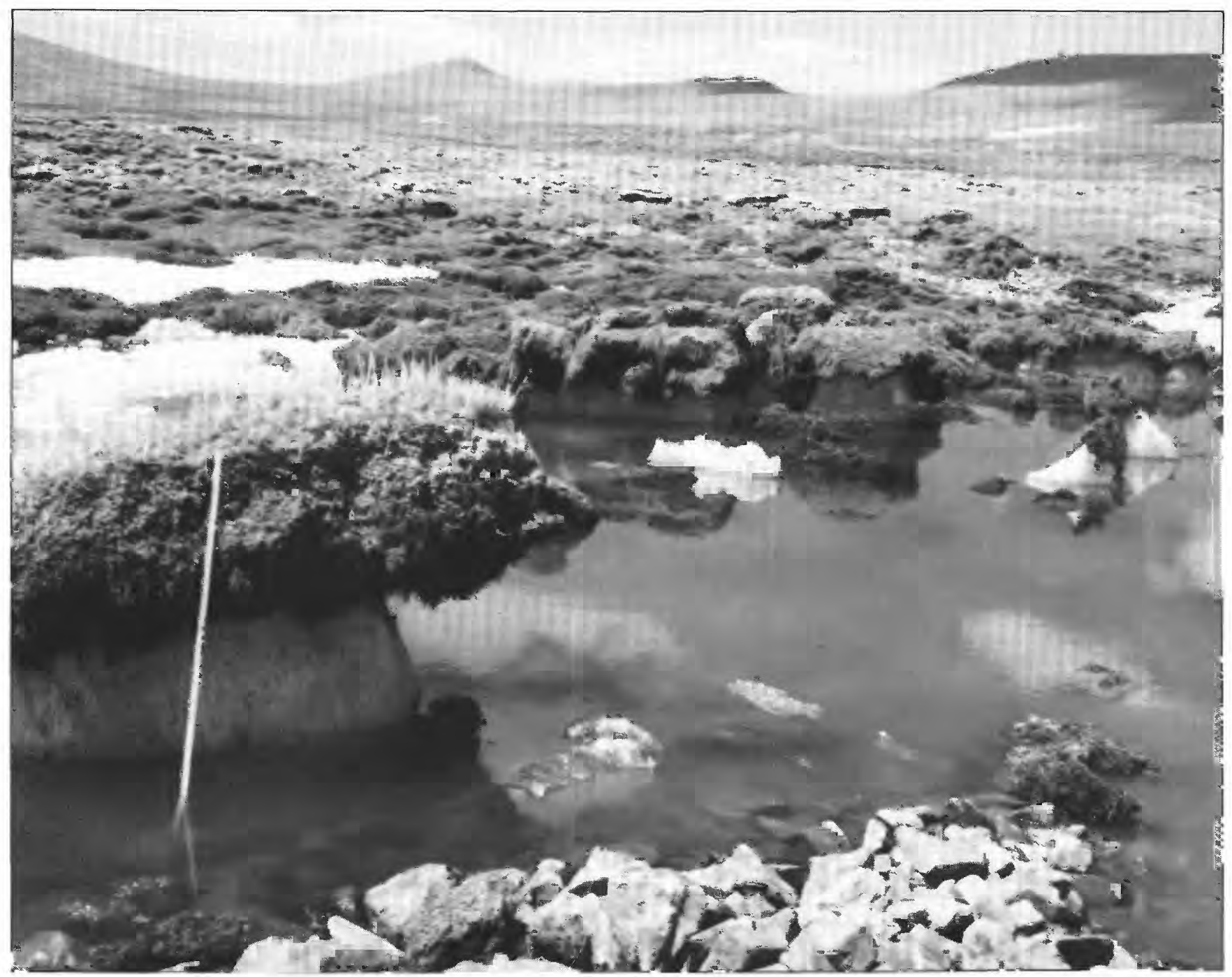




\section{LOESSLIKE SILT DEPOSITS}

\section{DISTRIBUTION AND THICKNESS}

In the mountainous Qinghai-Xizang (Tibet) Plateau, loesslike silt occurs in the lowlands and on gentle adjacent slopes; it is absent on the steep slopes and active flood plains (fig. 21). The silt is retransported loess that is thickest near major rivers and on parts of low fans, pediments, and river terraces. It lies in a belt between the major mountain ranges and the active flood plains, which are locally spotted with sand dunes or eolian sand blankets. This distribution of retransported loess is similar to that 1,400 $\mathrm{km}$ to the north in western Xinjiang Uygur Autonomous Region on the south and north sides of the Tian Shan (fig. 5; Péwé, 1987; Wang and Song, 1983).

Most of the loesslike silt has been slightly to considerably reworked and transported downslope by rill wash, sheet wash, stream action, and solifluction. As much as 1 to $2 \mathrm{~m}$ of silt still lies on a bedrock knob (fig. 22) $15 \mathrm{~m}$ above the Nyang Qu at Xigaze, and as much as $6 \mathrm{~m}$ of loesslike silt blankets the high flanks of a limestone knob $100 \mathrm{~m}$ above the south side of the Yarlung Zangbo $60 \mathrm{~km}$ downstream from Xigaze. The flanking silt is deeply dissected by deep, vertical-walled gullies (figs. 23, 24).

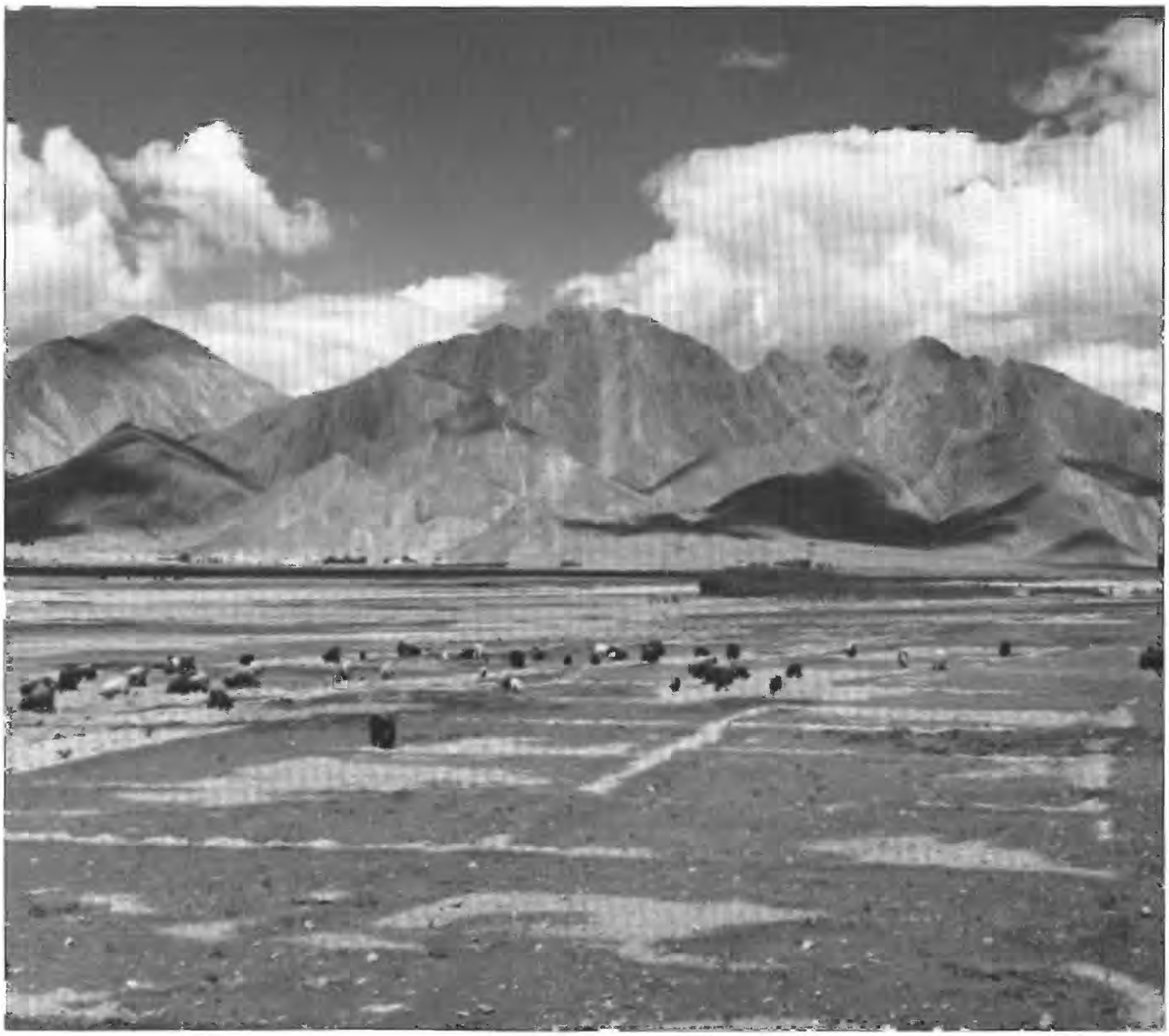

Figure 12. Broad flood plain of a north-flowing tributary of the Yarlung Zangbo about $40 \mathrm{~km}$ west of Xigaze, Xizang Autonomous Region, China. Area has barely enough vegetation to support a few herds of yak and dzo. Retransported loess occurs in lower valleys at base of folded Cretaceous rocks which form the east-facing mountains in background. Photograph 4581 by Troy L. Péwé, June 1980; reprinted from Péwé (1981) and published with permission of "Geotimes." 


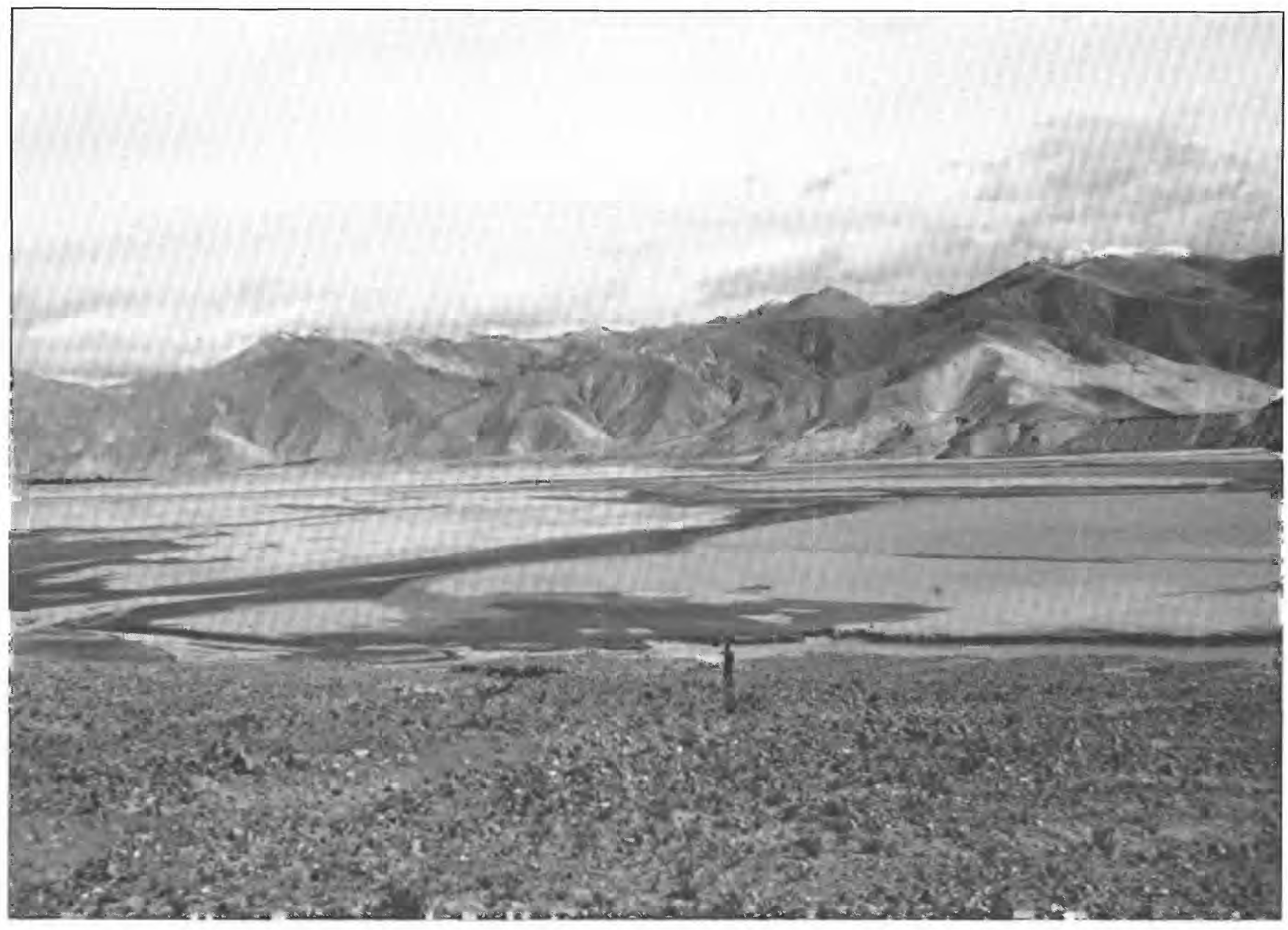

Figure 13. Broad, almost vegetation-free flood plain of braided Yarlung Zangbo is a ready source of wind-blown silt about $15 \mathrm{~km}$ east of Xigaze, Xizang Autonomous Region, China. Late Mesozoic granodiorite forms south-facing mountains in background. Photograph PK 23,902 by Troy L. Péwé, June 9, 1980.

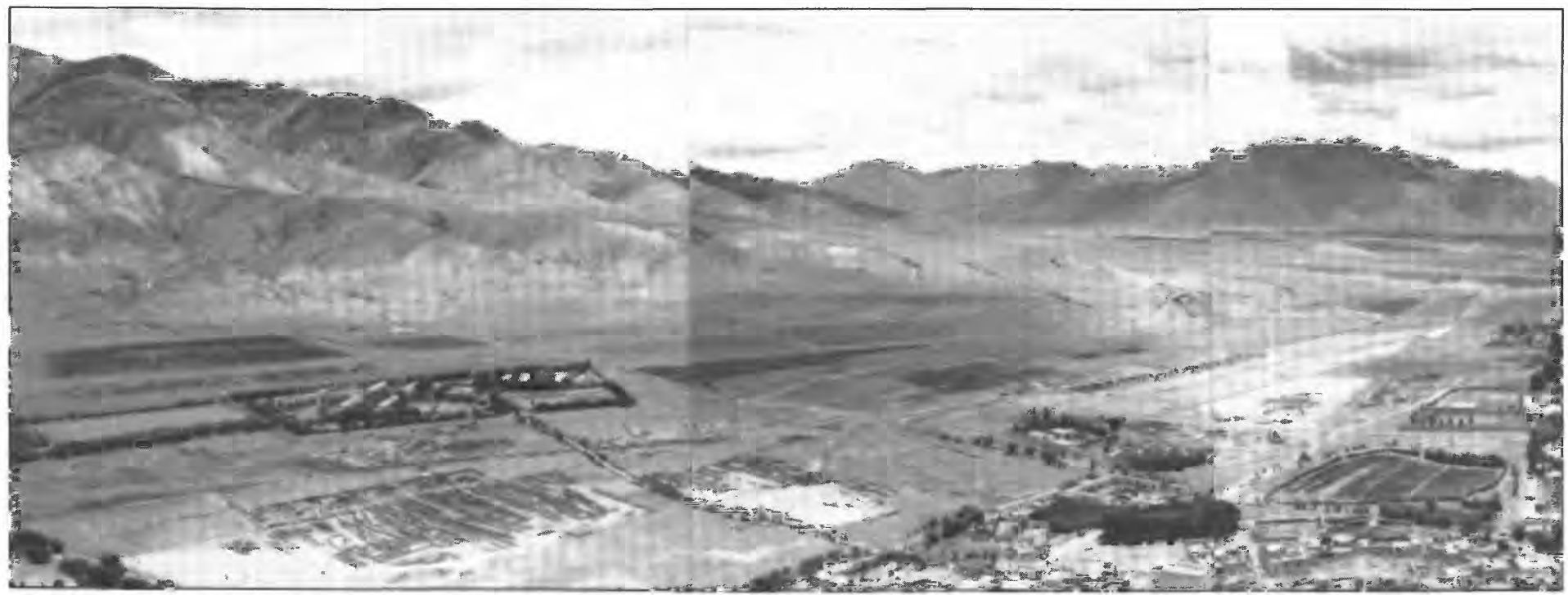

Figure 14. View southeast (upstream) of Nyang Qu valley from fortress on rock knob in valley at Gyangse, Xizang Autonomous Region, China. Fortress originally built by Tibetans as defense against Mongols. For thousands of years, a braided stream wandered across this broad, almost vegetation-free flood plain, now spotted with sand dunes. Winds picked up silt and blew dust onto bounding hills. Broad valley is now irrigated and 


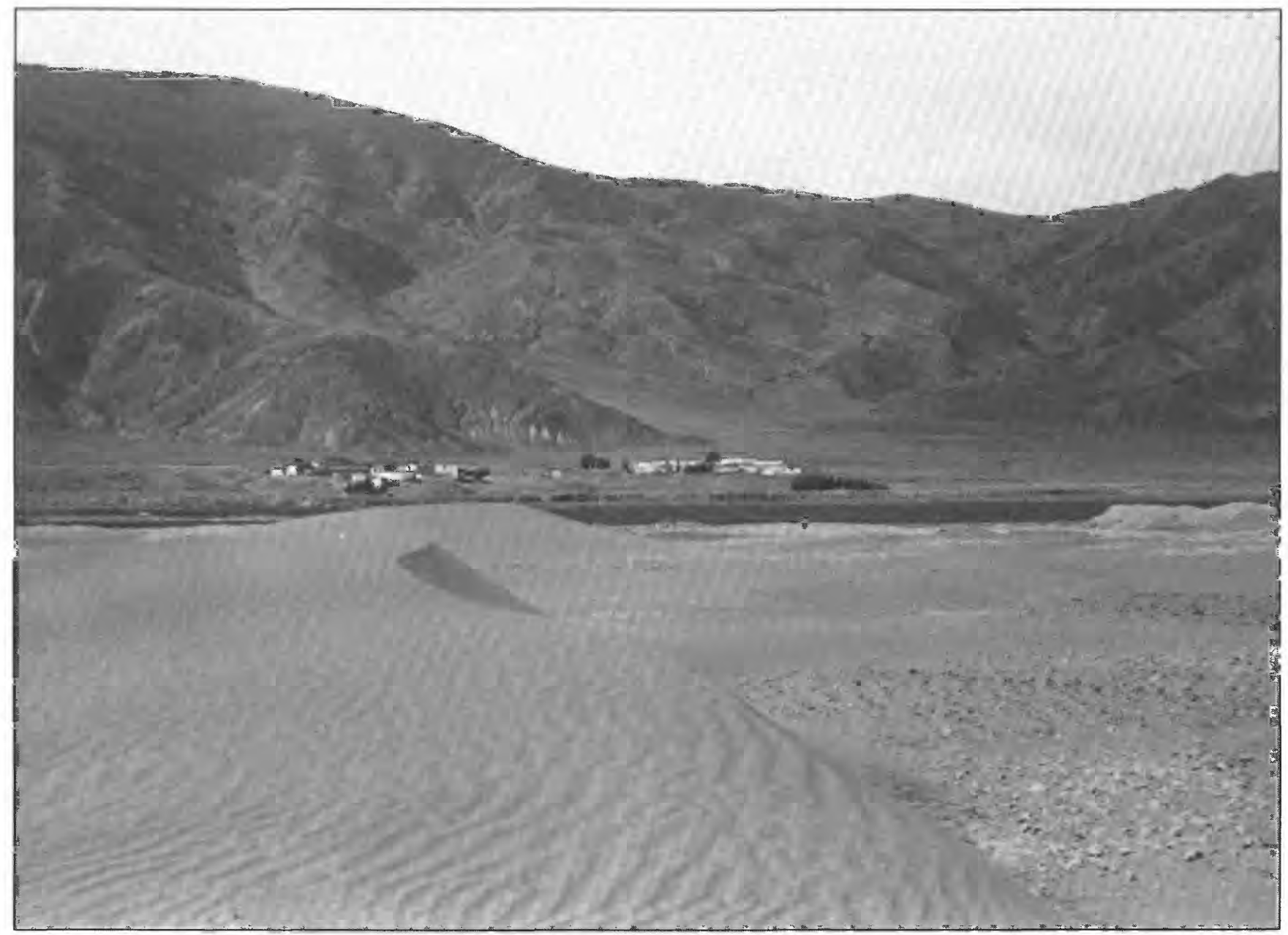

Figure 15. Active sand dunes on flood plain of Nyang Qu about $7 \mathrm{~km}$ southeast of Xigaze, Xizang Autonomous Region, China. View south. Photograph PK 23,871 by Troy L. Péwé, June 8, 1980.

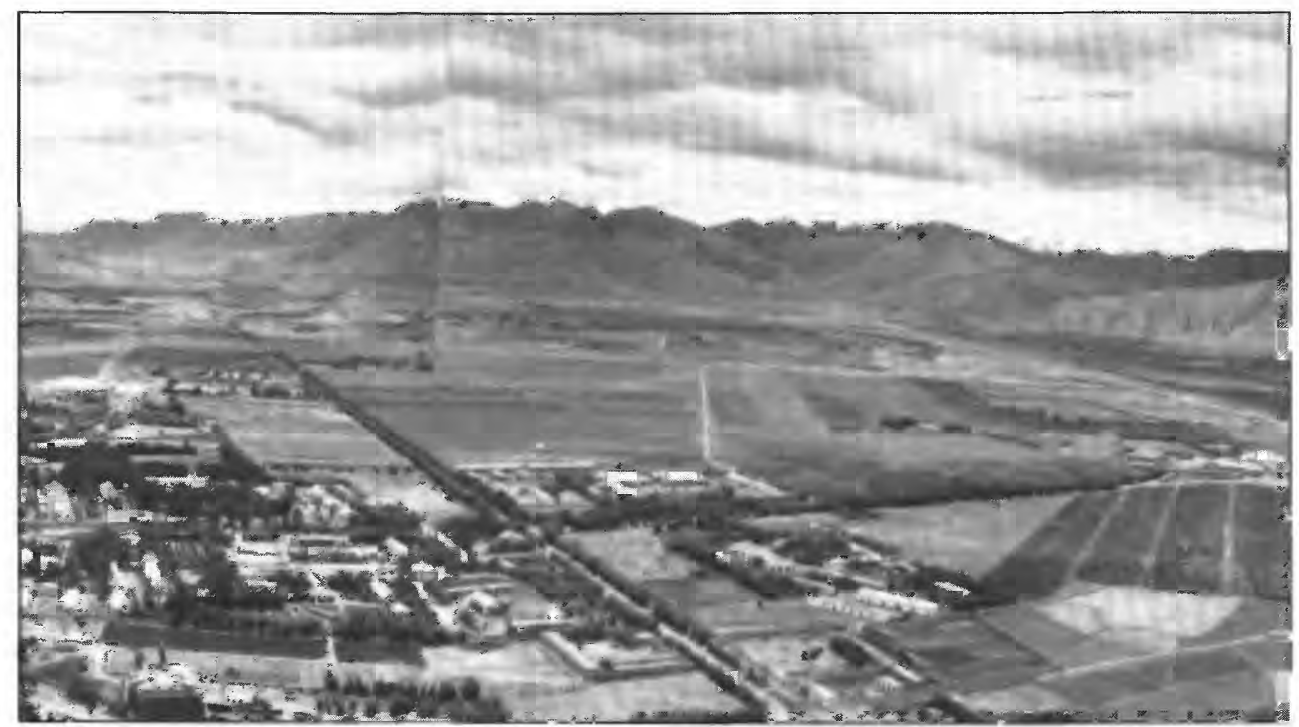

supports crops for city of Gyangse, foreground, in center of valley. Note steep-sided gullies cut into fans of retransported loess along left edge of river valley. Surrounding hills composed of Jurassic and Cretaceous sandstone, limestone, and shale. Photographs 4572-4576 by Troy L. Péwé, June 8, 1980. 
About 10 to $20 \mathrm{~m}$ of loesslike silt covers the lower northwestern slope of a hill at Yangbajain at the southern foot of the Nyainqentanglha Shan (fig. 3; Academia Sinica, 1980, fig. II-2; Wang and Li, 1983, fig. 2-25, p. 52). Loesslike silt is most widely distributed where it spreads out as fans 1 to $2 \mathrm{~m}$ thick on or near the edges of flat, gently sloping valley floors. The fans are rarely all silt; they include layers of sand and fine gravel that permit higher angle fans than would be preserved if they were composed only of silt.

Narrow, steep-walled gullies in the loesslike silt are similar, but on a much smaller scale, to the spectacular results of loess erosion in north-central China (Wang and Zhang, 1980; Wang and Song, 1983). Except along terraces and valley-bottom deposits, thickness is difficult to measure; however, studies of gullies in the fans indicate that the loesslike silt is about 1 to $6 \mathrm{~m}$ thick.

Reports of loesslike silt on the plateau outside of the route of our 1980 investigation are not common. Zhao and others (1976, p. 20), on the basis of early expeditions to the
Himalayas in 1966-68, report a thin (1-m) loesslike silt overlying the first, second, and outwash terraces of Gyirong valley in the southwest part of the plateau (fig. 3). They also describe as much as $10 \mathrm{~m}$ of eolian loesslike silt and colluvium overlying the terrain near the bridge over the Pum Qu, $5 \mathrm{~km}$ south of Tingri (fig. 3). Also from the Himalayan expeditions in the 1970's, Wang and Li (1983) describe loesslike deposits on slopes in the southern Xizang Autonomous Region. Xu (1980, 1981) reports what he called extensive "periglacial" loess deposited in late Pleistocene time on the slopes of the Tanggula Shan (figs. 2, 5) in the central part of the Qinghai-Xizang (Tibet) Plateau. Derbyshire (1985) records local thin loess deposits in Qinghai Province northeast of the plateau (fig. 1).

Huang (1980) reports yellowish sandy soil at Tingri and as much as $9 \mathrm{~m}$ of loessic mud and sandy soil at Xiegal. At Yangbajain (fig. 3) he reports $19.8 \mathrm{~m}$ of yellowish clay over yellow silty sand with some gravel and mammalian fossils (Huang, 1980, p. 50). He believes both the silt here and the loesslike silt at Lingtse County (area to the

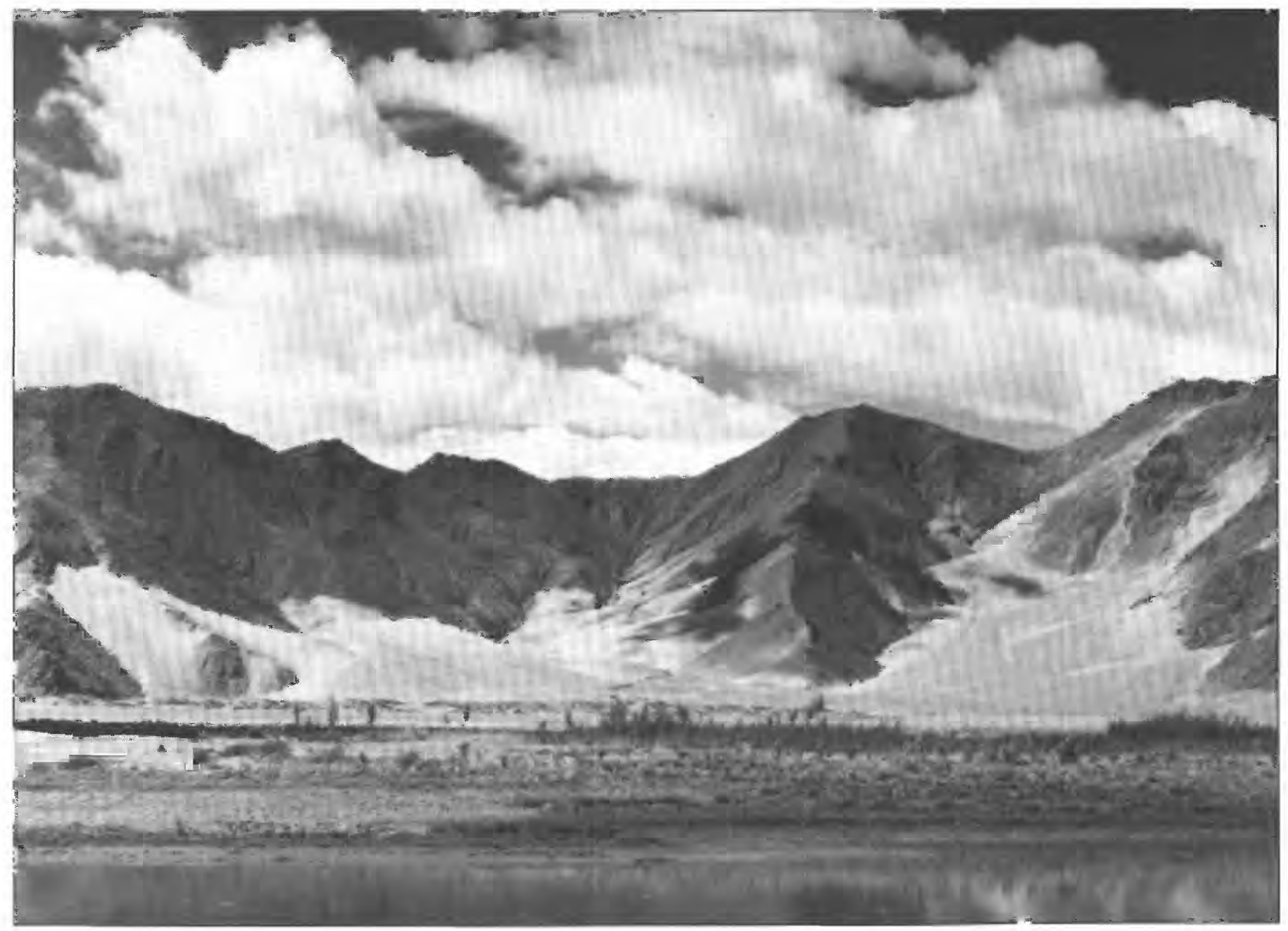

Figure 16. Climbing sand dunes on lower flanks of west-facing hills of Tertiary granite along braided Lhasa He $20 \mathrm{~km}$ southwest of Lhasa, Xizang Autonomous Region, China. Photograph 4547 by Troy L. Péwé, June 3, 1980; reprinted from Péwé (1981) and published with permission of "Geotimes." 
east around Nyingchi) are retransported loess (Huang Wanpo, oral commun., 1986). Yellowish silt is used for making brick and tile at Nyingchi.

The thickest deposits of loesslike silt are in valley bottoms and are commonly exposed in terrace scarps cut by streams (fig. 21). The deposits vary from relatively pure yellowish loess in vertical cliffs $10 \mathrm{~m}$ high to yellowish, fluvial, silty sand and silty clays that vary from less than a meter to $5 \mathrm{~m}$ thick.

The most striking and most extensive deposits of thick loesslike silt occur in the bottom of the Nyang Qu valley near its junction with the Yarlung Zangbo at Xigaze (fig. 25). There the Nyang Qu has cut down into a valleybottom deposit of retransported silt as thick as $15 \mathrm{~m}$. The eroded edges of the terraces on each side of the valley are vertical walls $15 \mathrm{~m}$ high of bedded silt with some sandy layers. The most striking land forms are steep-sided flattopped buttes and mesas, the latter as much as $1 \mathrm{~km}$ in diameter, that remain in the valley bottom (fig. 26). These erosional remnants clearly exhibit the vertically jointed retransported silt. The tops of the erosional remnants are bare of vegetation, perhaps because they are well drained and very dry. Similar land forms in retransported loess have developed on the south side of the Tian Shan in the Xinjiang Uygur Autonomous Region (Péwé, 1987).

Probably the most thoroughly studied section of retransported loess in the Qinghai-Xizang (Tibet) Plateau is along the main highway at the south edge of Xigaze (fig. 27). About $15 \mathrm{~m}$ of alternating beds of retransported loess, sandy loess, and sand are exposed, and the uppermost $6 \mathrm{~m}$ are easily accessible for collecting samples and fossils. Beds of relatively pure, cliff-forming, yellowish silt as thick as $3 \mathrm{~m}$ are quite impressive (fig. 28).

\section{COLOR AND TEXTURE}

The loesslike silt is commonly yellowish tan (fig. 28), although grayish-tan is not rare; when wet it is brown. In many localities thin, dark, carbonaceous and iron-stained bands or mottling are present.

Mechanical composition of the loesslike silt and associated sandy silt and sand was measured on 17 samples from the plateau and 3 samples of loess and retransported loess

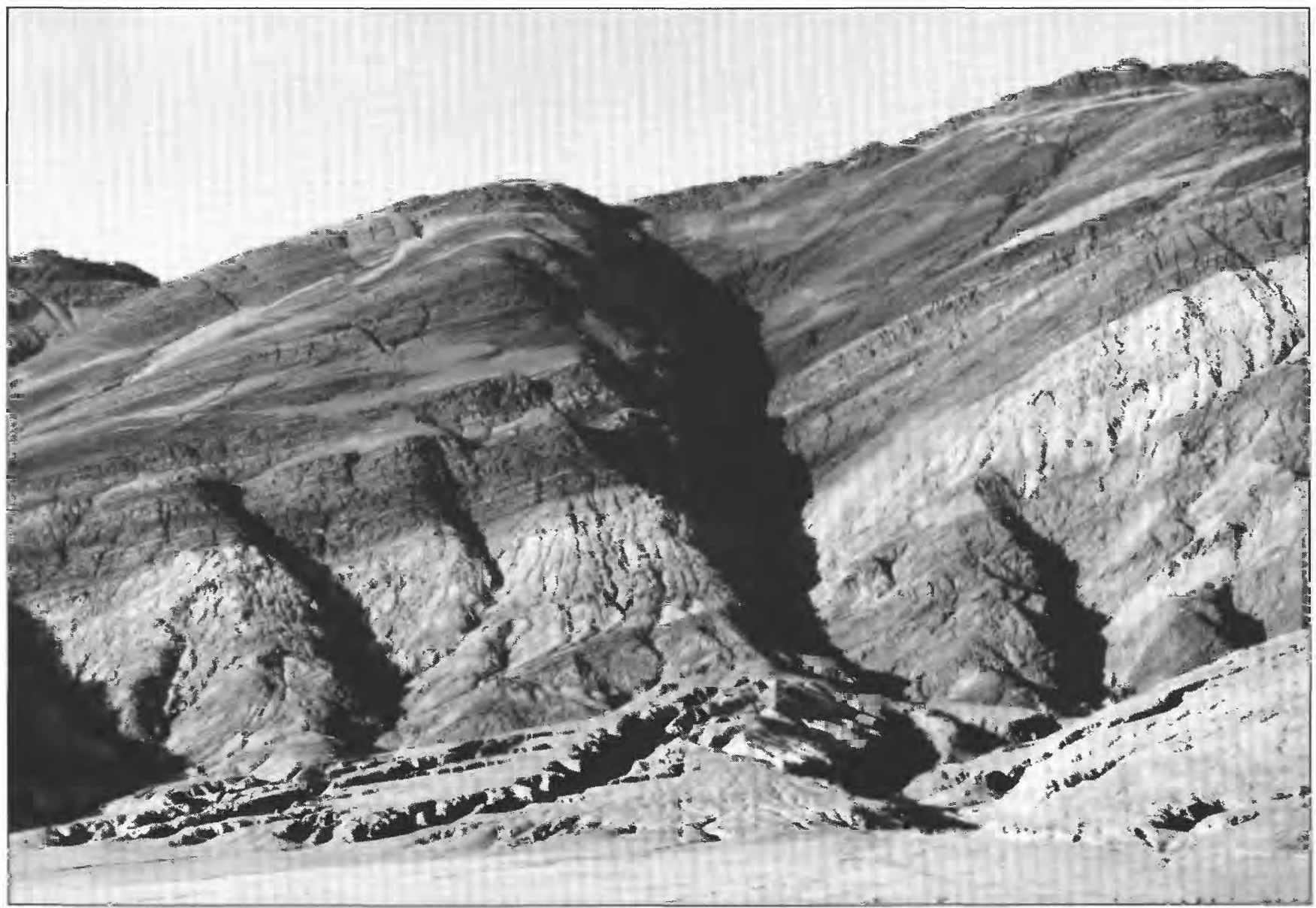

Figure 17. Sharply dissected fans of retransported loess at base of low west-facing mountains east of Tingri, Xizang Autonomous Region, China. Photograph 4584 by Troy L. Péwé, June 11, 1980. 


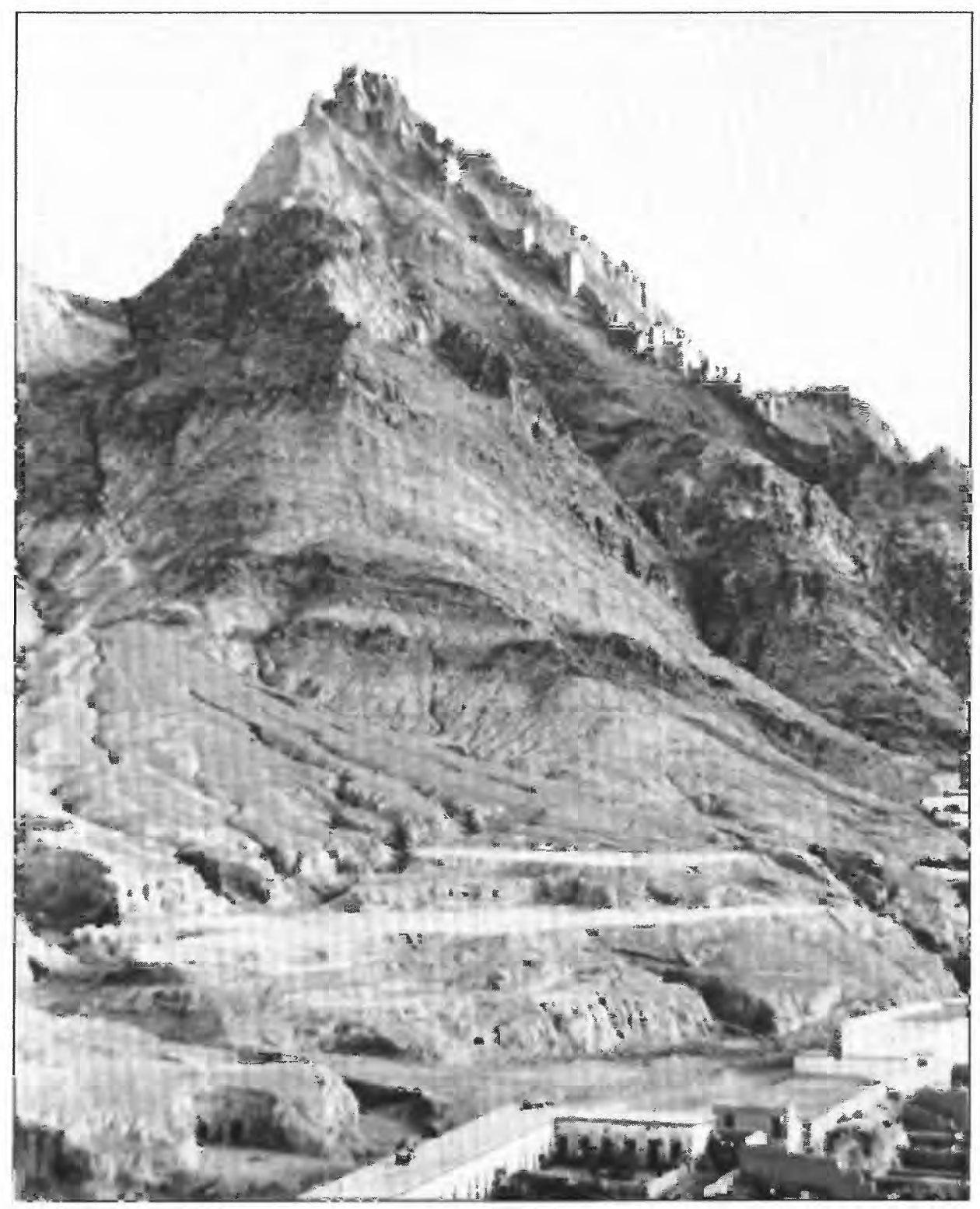

Figure 18. Large dissected fan of retransported loess below site of Tibetan monastery and fortifications of Xigar-Zhong, seat of district administration during Ching Dynasty, at Tingri in south-central Xizang Autonomous Region, China. Mountain of tilted shale and sandstone of Jurassic age. Note difference in use of fan for building sites in each picture. $A$, Early morning sun strikes remnants of once-splendid fortifications high on mountain. Loess is easily excavated, and small entrances to storage rooms can be seen in scarp at base of fan. Fan has been planed off in steps to accommodate modern buildings as city of Tingri expands. Photograph PK 23,950 by Troy L. Péwé, June 12, 1980.

from elsewhere in China (table 1). Grain-size analyses of samples 1 through 10 , and a sample of loess from near Heidelberg, Germany, were made by wet sieving to separate the $>0.062 \mathrm{~mm}$ fraction, then pipetting that fraction at whole phi-size intervals according to the method of Folk (1974). Samples 11 through 17 were wet sieved, and calcium car- bonate was removed before grain-size analyses were made by hydrometer. Samples 18 and 19 were wet sieved and further analyzed by the hydrometer method. Loess sample 20 from near Beijing was analyzed by sedimentation in water.

The powdery loesslike silty sediment is widespread in fans of different localities, shapes, and sizes and on 


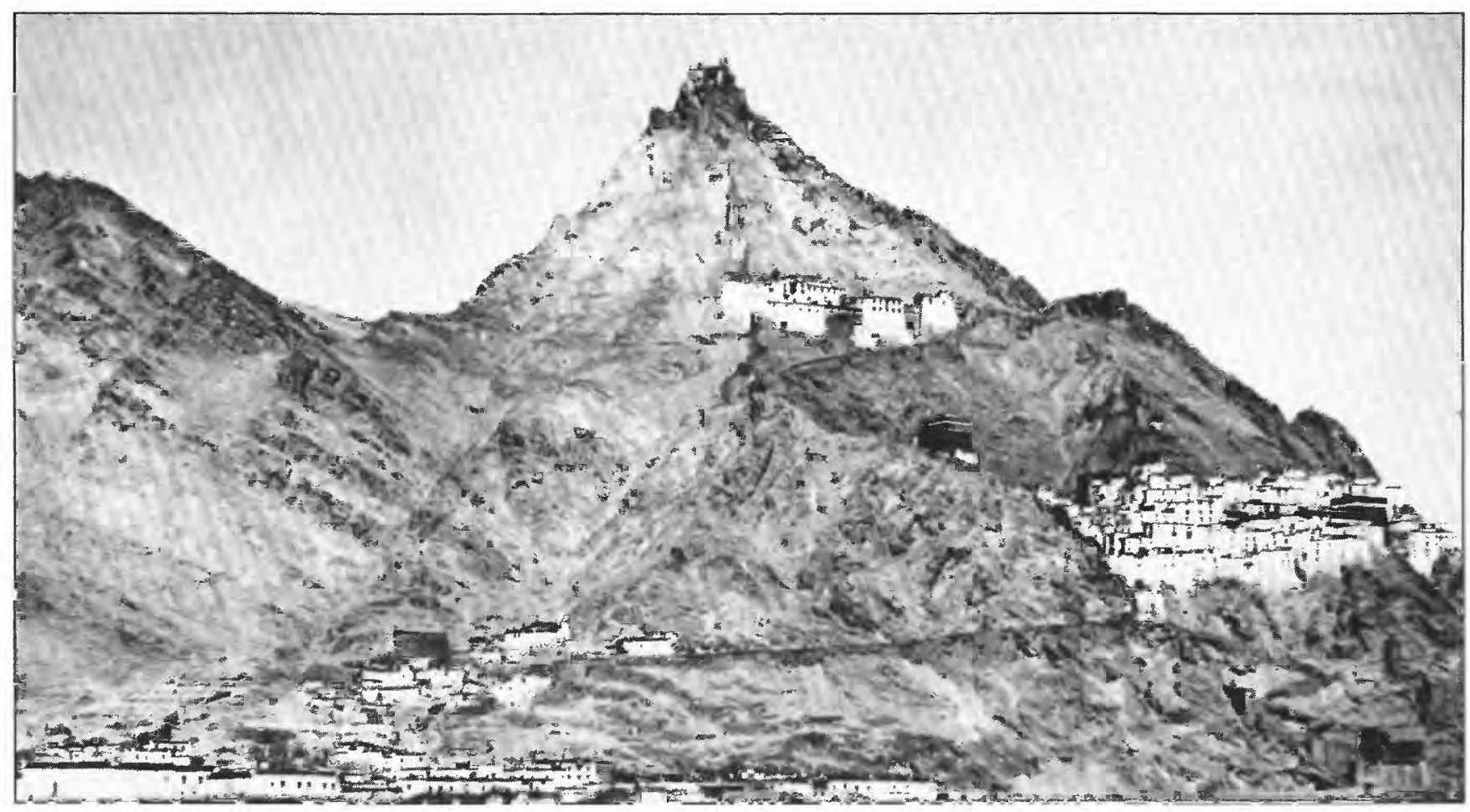

Figure 18. B, View southeast toward intact monastery and fortifications on same hillside in 1922. Copyright photograph 092207-D525 by T.G. Longstaff, MEE, while on reconnaissance expedition to Mount Everest. Published with permission of Royal Geographic Society, London.

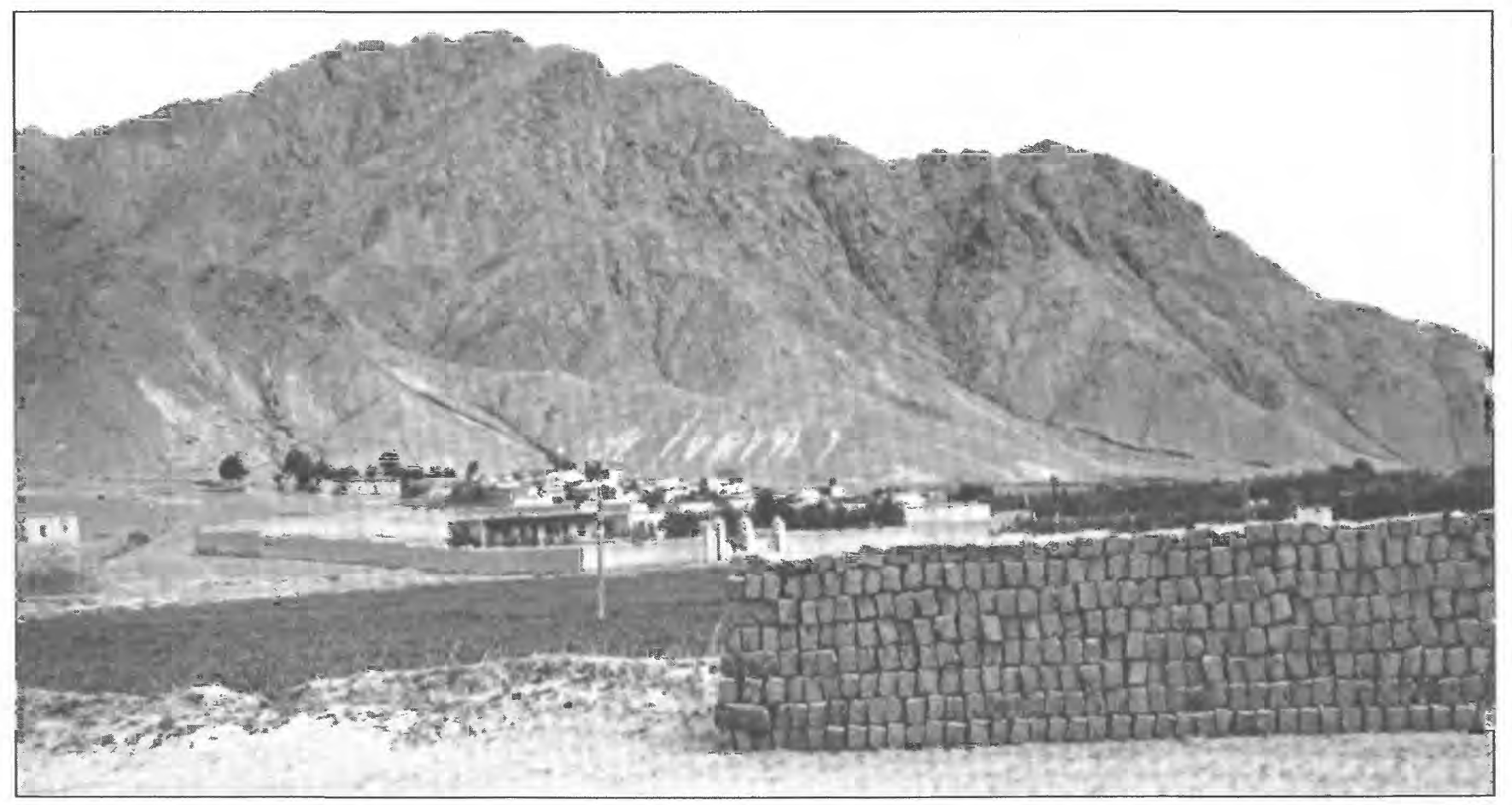

Figure 19. Newly made bricks of loess in foreground, loess-brick walls around house in center. View west across valley of Nyang Qu near Bainang, about $45 \mathrm{~km}$ southeast of Xigaze, Xizang Autonomous Region, China. Photograph PK 23,878 by Troy L. Péwé, June 8, 1980. 
Table 1. Data on Quaternary sediment samples collected from southern Qinghai-Xizang (Tibet) Plateau, China, and from other parts of China.

[Samples collected by T.L. Péwé except as noted. Mineralogy analysis includes clay minerals and rock fragments.]

Analyses performed

Sample No.
(figure) $\quad$ Material $\quad \begin{gathered}\text { Date } \\ \text { collected }\end{gathered} \quad$ Sample site $\quad$ Position and stratigraphy at site $\quad$ Age

Granulo- Mineral- Pollen Ostra- Mol- Vertemetric ogy codes lusca brates

\begin{tabular}{|c|c|c|c|}
\hline $\begin{array}{c}1 \\
\text { (figs. } 3,34 \text { ) }\end{array}$ & $\begin{array}{l}\text { Retransported } \\
\text { sandy loess. }\end{array}$ & $6 / 8 / 80$ & $\begin{array}{l}\text { Bainang Agricultural Station, } \\
\text { elevation } 3,900 \mathrm{~m} \text {, in Nyang } \\
\text { Qu Valley, } 40 \mathrm{~km} \mathrm{NW} \text { of } \\
\text { Gyangze }\end{array}$ \\
\hline $\begin{array}{c}2 \\
\text { (figs. } 3,34 \text { ) }\end{array}$ & Silty sand............ & $6 / 8 / 80$ & $\begin{array}{c}\text { In Nyang Qu Valley, } 22 \mathrm{~km} \\
\text { upstream from Xigaze. }\end{array}$ \\
\hline $\begin{array}{c}3 \\
\text { (figs. } 3,22, \\
25,34)\end{array}$ & Sandy loess........ & $6 / 9 / 80$ & $\begin{array}{l}\text { On bedrock hill } 60 \mathrm{~m} \text { above } \\
\text { river at junction of Nyang Qu } \\
\text { and Yarlung Zangbo, north } \\
\text { side of Xigaze. }\end{array}$ \\
\hline $\begin{array}{c}\quad 4 \\
\text { (figs. } 3,34 \text { ) }\end{array}$ & Sandy loess ....... & $6 / 9 / 80$ & $\begin{array}{l}\text { On flank of bedrock hill } 15 \mathrm{~m} \\
\text { above and adjacent to } \\
\text { Yarlung Zangbo, } 50 \mathrm{~km} \\
\text { downstream from Zigaze on } \\
\text { south side of river. }\end{array}$ \\
\hline $\begin{array}{c}5 \\
\text { (figs. } 3,27 \text {, } \\
34 \text { ) }\end{array}$ & $\begin{array}{l}\text { Retransported } \\
\text { loess (same } \\
\text { as sample No. } \\
\text { 15). }\end{array}$ & $6 / 9 / 80$ & $\begin{array}{l}\text { On face of terraces of silt and } \\
\text { sand (distal end of fans from } \\
\text { hills), west side of Nyang Qu } \\
\text { at south edge of Xigaze. }\end{array}$ \\
\hline $\begin{array}{l}\quad 6 \\
\text { (figs. } 3,34)\end{array}$ & $\begin{array}{l}\text { Retransported } \\
\text { loess. }\end{array}$ & $6 / 10 / 80$ & $\begin{array}{l}\text { Agricultural field on } \\
\text { retransported loess at village } \\
\text { of Netang, } 14 \mathrm{~km} \text { west of } \\
\text { Xigaze. }\end{array}$ \\
\hline $\begin{array}{c}7 \\
\text { (figs. } 3,34)\end{array}$ & $\begin{array}{l}\text { Retransported } \\
\text { loess. }\end{array}$ & $6 / 10 / 80$ & $\begin{array}{l}1 \mathrm{~km} \text { west of village of Jaling, } \\
75 \mathrm{~km} \text { west of Xigaze. }\end{array}$ \\
\hline
\end{tabular}

8 Retransported

(figs. 3, 34) loess.

9 Silty pebbly

(figs. 3, 34) retransported

loess.

$10 \quad$ Eolian sand ${ }^{1}$...

(figs. 3, 34) Retransported

(figs. 3, 27) loess ${ }^{\text {. }}$.

12 Silty sand 1 . (figs. 3, 27)

13 Retransported

(figs. 3, 27) loess ${ }^{1}$.

14 Retransported

(figs. 3, 27) loess ${ }^{\mathrm{P}}$.

15 Retransported

(figs. 3, 27) loess (same as sample No. 5) 1 .

16 Retransported

(figs. 3, 27) loess and sandy loess 1

17 Crossbedded

(figs. 3, 27) sand 1 .

18 Retransported

(figs. 5, 42, loess.

$\begin{array}{ll}45 & \\ 19 & \text { Retransported }\end{array}$

(figs. 5, 45 gravely loess.

$$
\underset{20}{(\text { fig. } 1)} \text { Loess }^{2}
$$

6/11/80 Dissected alluvial fan of silt 15 $\mathrm{km}$ east of Lhaze.

6/12/80 $70 \mathrm{~km}$ west of Tingri on south side of Pum Qu valley.

6/17/80 $45 \mathrm{~km}$ southwest of Lhasa along west side of Lhasa He.

6/18/80 Terrace on west side of Nyang $\mathrm{Qu}$, south side of Xigaze.

6/18/80 Terrace on west side of Nyang Qu, south side of Xigaze.

6/18/80 Terrace on west side of Nyang $\mathrm{Qu}$, south side of Xigaze.

6/18/80 Terrace on west side of Nyang $\mathrm{Qu}$, south side of Xigaze.

6/18/80 Terrace on west side of Nyang $\mathrm{Qu}$, south side of Xigaze.

6/18/80 Terrace on west side of Nyang $\mathrm{Qu}$, south side of Xigaze.

6/18/80 Terrace on west side of Nyang Qu, south side of Xigaze.

8/6/86 Ancient city of Jiaohe, near Turpan, Xinjiang Uygar Autonomous Region.

8/10/86 West bank of Sigh He at Kuqa, north of Tarim Basin, Xinjiang Uygar Autonomous Region.

1973 Near Beijing.
Surface sample in field at base of alluvial fan of silt with some gravel.

Surface sample in silty field at base of rock cliff on low terrace.

At depth of $2.4 \mathrm{~m}$ in loess plastered on hill of volcaniclastic sandstone.

At depth of $2 \mathrm{~m}$ in gully of loess blanketing a bedrock hill of limestone.

Unit III, $3.6 \mathrm{~m}$ below surface in Late bank of retransported fossilif- Pleistocene. erous loess and alluvial sand

Near-surface sample on very gently sloping fan.

At depth of $3.0 \mathrm{~m}$ in broad fan of black gravel of angular clasts, $2-4 \mathrm{~cm}$ diam.; gravel $2.5 \mathrm{~m}$ thick over 2.5 -m layer of loess with $0.3-\mathrm{cm}$ zone of red soil at base.

Surface silt on fan.

Surface-sediment sample.

\section{(1)}

Surface-sediment sample.........

Unit VI, $0.9 \mathrm{~m}$ below surface.. Late

Unit V, $1.4 \mathrm{~m}$ below surface..

Unit IV, $1.8 \mathrm{~m}$ below surface.

Unit IV, 2-3 m below surface.

Unit IIl, $3.6 \mathrm{~m}$ below surface... Holocene.....

Unit II, $4.8 \mathrm{~m}$ below surface..... Late

Unit $1,5.5 \mathrm{~m}$ below surface...... $\quad \begin{aligned} & \text { Late } \\ & \text { Pleistocene. }\end{aligned}$

30-m vertical loess wall of small creek valley. Sample from $2.0 \mathrm{~m}$ below surface.

Alluvial loess and gravel

layers, 1-3 m thick. Sample

from $3 \mathrm{~m}$ below surface.

Surface sample
Holocene....

Holocene...

Holocene...... X $X$

X $\quad X$

Holocene......

X X

Pleistocene.

$\mathrm{X}$

$\mathrm{X}$

$\mathrm{X}$

X

X X

Pleistocene.

Late
Pleistocene.

Late

Pleistocene.

Late

Pleistocene.

Late

Pleistocene.

$\mathrm{X}$

$\mathrm{X}$

X

X

$\mathrm{X}$

Late

Pleistocene.

Late

Pleistocene.

Late

Pleistocene.
X $\mathrm{X}$

\footnotetext{
${ }^{1}$ Collected by Liu Tungsheng and Li Bingyuan.

${ }^{2}$ Collected by Roger J.E. Brown.

${ }^{3}$ See Péwé and Journaux (1983) for mineral analyses.
} 
hills of different bedrock types. The silt varies widely in texture and sorting from clay-rich to sand-rich and even to gravel-rich, depending upon nearness to the original silt source and the various distances of retransportation and mixing with other sediments by fluvial and colluvial slope movement. Silt near the hills or mountain slopes is coarser and interbedded with more coarse beds than that at the toe of low-angle silt fans near the center of the valleys. In great contrast to the uniform mechanical composition and texture of loess throughout the world (table 2; Péwé and Journaux, 1983, their figs. 28, 29), this retransported loess is less well sorted and generally has a lower percentage of silt-size particles (table 3, figs. 29, 30) than in situ loess. Percentages of grain sizes in silt samples vary: 8 to 55

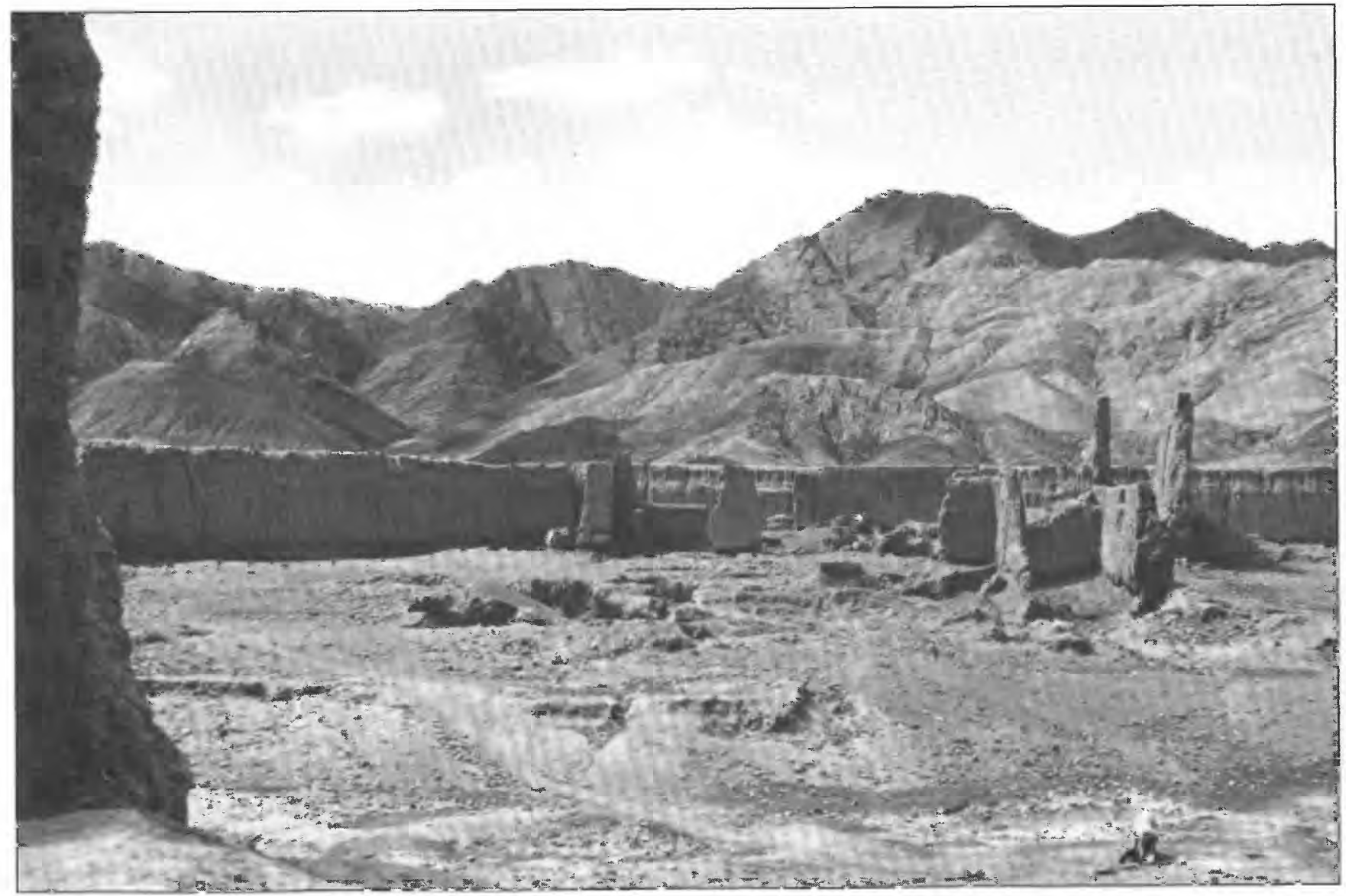

Figure 20. Remnants of loess-brick walls of 13 th century monastery about $10 \mathrm{~km}$ west of Xigaze, Xizang Autonomous Region, China. View west. Photograph PK 23,918 by Troy L. Péwé, June 10, 1980.

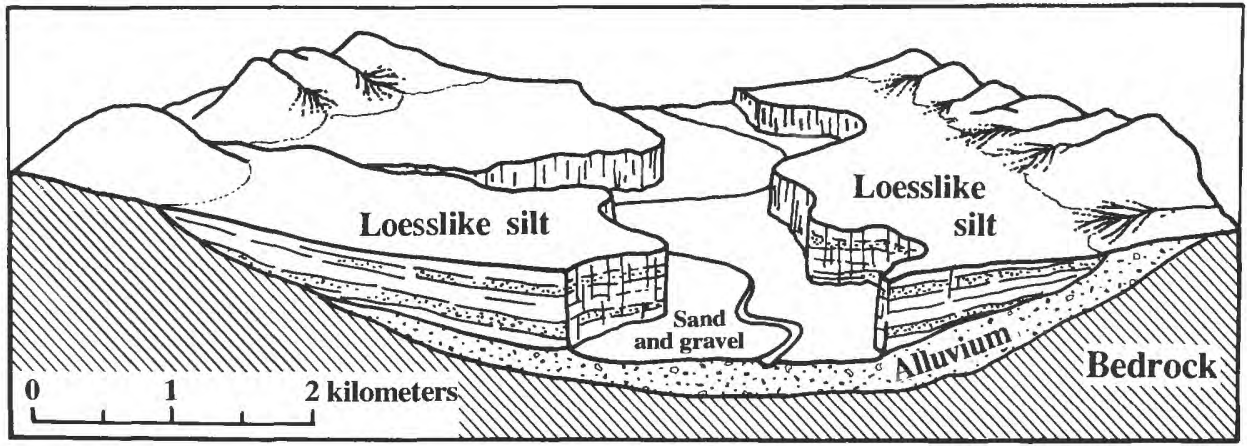

Figure 21. Diagrammatic sketch of typical dissected loesslike silt with lenses and layers of fluvial sand and gravel in valley bottoms along major streams in southern Qinghai-Xizang (Tibet) Plateau, China. Vertical exaggeration $33 \times$. Diagram by S.M. Selkirk. 
percent sand; 26 to 75 percent silt; and 2 to 67 percent clay (table 3 ).

However, loess on or flanking bedrock knobs or hilltops near the Yarlung Zangbo was retransported little or not at all; it is well sorted and has a relatively high sand content and a low clay content (fig. 31). The silt has the same texture throughout the section from the surface to the bedrock. Texture and cumulative-frequency grain-size curves of the sandy loess from near rivers (samples 3 and 4) are similar to those of sandy loess adjacent to braided streams in Alaska, Siberia, and elsewhere (Péwé and Holmes, 1964; Trainer, 1961; Péwé and Journaux, 1983). Samples 5, 7, 13, 14, 15, and 16 have more than 40 percent clay-size particles (figs. 30,32 ) and are typical of silt deposits on fans. Huang (1980) refers to loessic mud at Tingri and yellowish clay at Yangbajain. Sample 6, which has the highest silt content (fig. 30) and is best sorted, is from an agricultural field on the toe of the slope far from the mountains. Some samples have fluvial silty sand and some have eolian sand (fig. 33). Fluvial sand is interbedded with the loesslike silt in many localities.
Silt grains in the loesslike silt are angular, and the sediment has little or no cementation. A few calcareous concretions (loess kindshen) are present locally. The presence of an expandable mixed-layer clay and stringers of calcite and small roots in some samples indicates that these sediments have been subject to soil-forming processes.

\section{MINERAL COMPOSITION}

Mineralogical analyses of 10 sediment samples from southern Qinghai-Xizang (Tibet) Plateau were compared with that of a control sample of loess from Germany. Mineral composition of the sand-size fraction of samples 1 through 10 (table 4) was determined by impregnating the sand in epoxy resin, which allowed thin sections to be prepared, then using a petrographic microscope for point counting 200 grains. Petrographic examination reveals that the silt grains, although slightly iron stained, are angular and fresh.

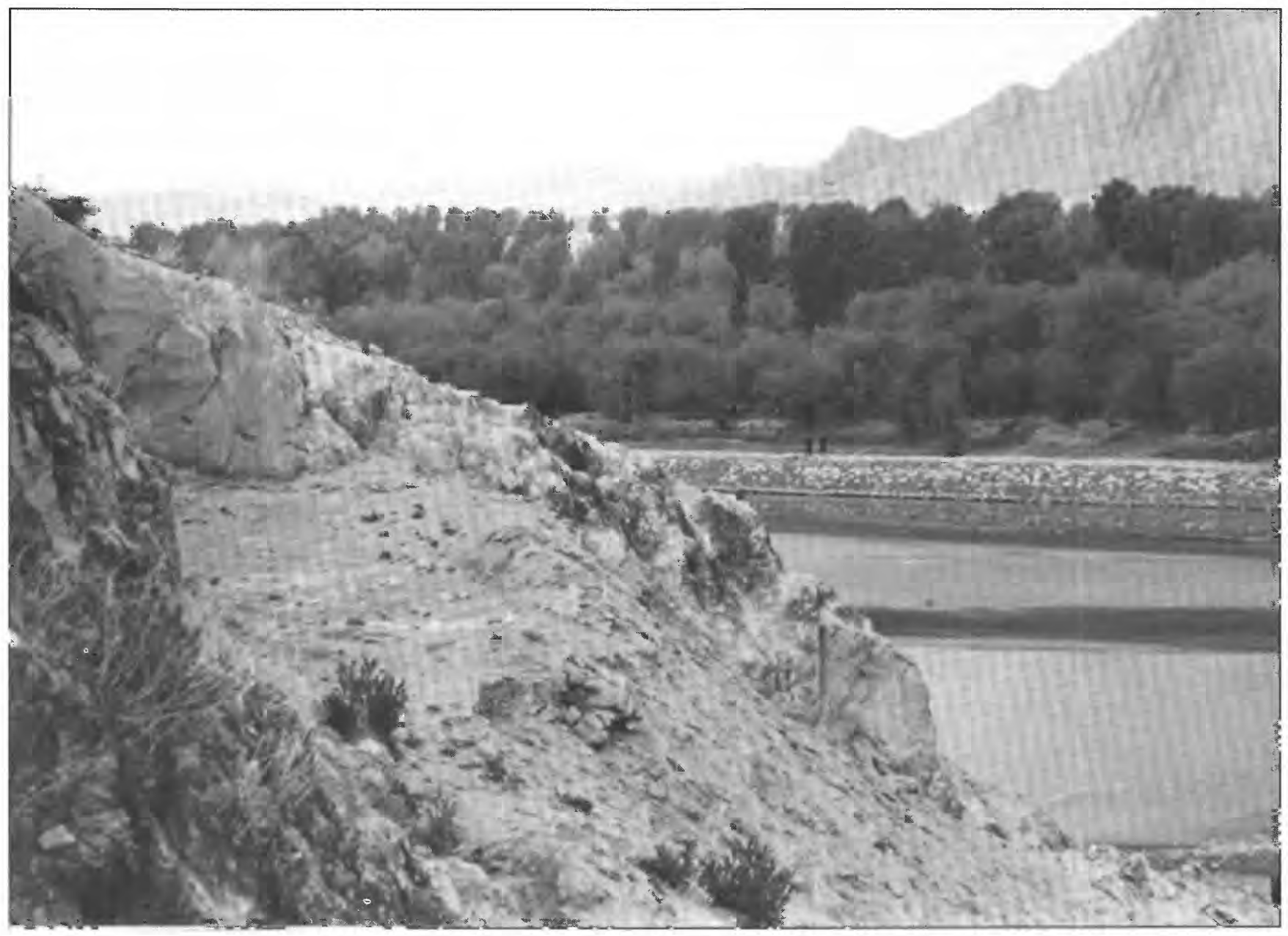

Figure 22. Loess overlying bedrock on knob $15 \mathrm{~m}$ above the Nyang Qu at Xigaze, Xizang Autonomous Region, China. Collection site of sample 3 (table 1). Photograph PK 23,896 by Troy L. Péwé, June 9, 1980. 
Table 2. Mechanical properties of sand and loesslike-silt samples from southern Qinghai-Xizang (Tibet) Plateau, China (Nos. 1-19), and loess and ash from other parts of the world.

[Sedimentological terms from Folk (1974). Compiled by Mu Guijin from cumulative-frequency curves (figs. 30-33). See table 1 for sampling information.]

\begin{tabular}{|c|c|c|c|c|c|c|}
\hline $\begin{array}{l}\text { Sediment } \\
\text { sample } \\
\text { No. }\end{array}$ & Material & $\begin{array}{l}\text { Graphic mean } \\
(\mathrm{Mz}) \phi\end{array}$ & $\begin{array}{l}\text { Median } \\
\text { (Md) } \phi\end{array}$ & $\begin{array}{l}\text { Inclusive graphic } \\
\text { standard deviation } \\
\text { (sorting) }(\sigma \mathrm{I}) \phi\end{array}$ & $\begin{array}{l}\text { Inclusive graphic } \\
\text { skewness } \\
\left(\mathrm{S}_{\mathrm{KI}}\right)\end{array}$ & $\begin{array}{c}\text { Graphic kurtosis } \\
\left(\mathrm{K}_{\mathrm{G}}\right)\end{array}$ \\
\hline 1 & Retransported sandy loess.................................... & 5.42 & 4.84 & 2.00 & 0.43 & 0.96 \\
\hline 2 & 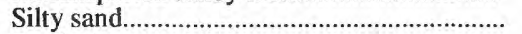 & 4.82 & 3.82 & 2.65 & .91 & .91 \\
\hline 3 & 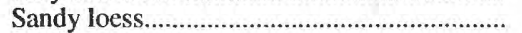 & 4.58 & 4.58 & 1.08 & .19 & 1.14 \\
\hline 4 & 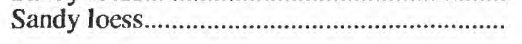 & 4.35 & 4.13 & 2.15 & .23 & 1.50 \\
\hline 5 & 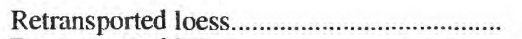 & 7.62 & 7.90 & 2.10 & -.27 & .87 \\
\hline 6 & Retransported loess............................................. & 5.32 & 5.35 & 1.46 & -.05 & 1.77 \\
\hline 7 & 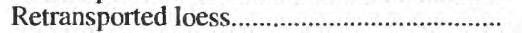 & 7.84 & 7.96 & 1.79 & -.16 & .77 \\
\hline 8 & 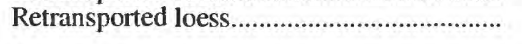 & 7.45 & 7.48 & 1.49 & -.04 & .90 \\
\hline 9 & Silty pebbly retransported loess........................... & 6.76 & 6.72 & 2.02 & -.01 & .84 \\
\hline 10 & 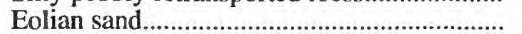 & 3.18 & 3.12 & 1.80 & .26 & 2.13 \\
\hline 11 & Retransported loess.............................................. & 6.34 & 5.80 & 2.24 & .31 & .72 \\
\hline 12 & $\begin{array}{l}\text { Silty } \\
\text { sand }\end{array}$ & \multicolumn{2}{|c|}{ No analyses available } & & & \\
\hline 13 & 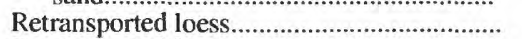 & 7.03 & 7.26 & 1.92 & -.15 & .88 \\
\hline 14 & Retransported loess........................................... & 6.57 & 6.65 & 2.99 & -.11 & .63 \\
\hline 15 & Retransported loess............................................... & 7.31 & 8.15 & 2.35 & -.45 & .84 \\
\hline 16 & Retransported loess and sandy loess............. & 6.2 & 6.50 & 3.18 & -.16 & .57 \\
\hline 17 & 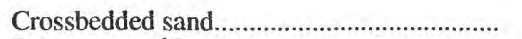 & \multicolumn{2}{|c|}{ No analyses available } & & & \\
\hline 18 & 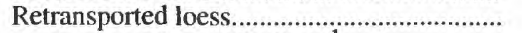 & 7.83 & 7.46 & 2.07 & .23 & 1.1 \\
\hline 19 & 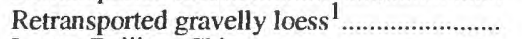 & 5.82 & 5.58 & 2.55 & .064 & 1.51 \\
\hline \multirow[t]{13}{*}{20} & Loess, Beijing, China & 7.94 & 7.65 & 2.84 & -.1 & .83 \\
\hline & Dust, Germany & 5.42 & 5.50 & 0.95 & .17 & 1.02 \\
\hline & Volcanic ash, Fairbanks, Alaska, U.S.A....... & 6.24 & 6.15 & 1.28 & .03 & 1.23 \\
\hline & 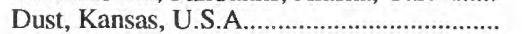 & 6.84 & 5.90 & 2.41 & .44 & 1.26 \\
\hline & Dust, Arizona, U.S.A. & 7.8 & 6.65 & 2.87 & .46 & 1.47 \\
\hline & 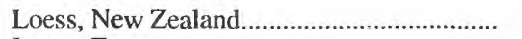 & 8.1 & 7.80 & 2.83 & .1 & .92 \\
\hline & 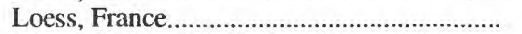 & 6.24 & 5.32 & 1.91 & .63 & 1.78 \\
\hline & Loess, former Czechoslovakia............................ & 7.37 & 5.95 & 2.96 & .56 & .98 \\
\hline & Loess, Alaska, U.S.A & 5.84 & 5.50 & 1.36 & .26 & 1.12 \\
\hline & 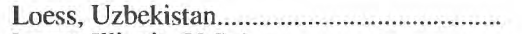 & 5.45 & 5.11 & 1.48 & .52 & \\
\hline & Loess, Illinois, U.S.A & 6.07 & 5.95 & 1.23 & .08 & 1.64 \\
\hline & Loess, Siberia, Russia............................................. & 5.58 & 5.27 & 1.87 & .43 & 1.86 \\
\hline & 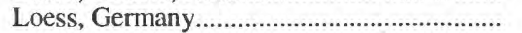 & 5.40 & 5.38 & .84 & .09 & 1.59 \\
\hline
\end{tabular}

${ }^{1}$ Original sample included about 15 percent gravel larger than $2 \mathrm{~mm}$, which was removed before this analysis.

Composition of bulk (not size-fraction) samples was determined by air drying, crushing to a uniform fine powder, then using X-ray diffraction analysis by using a Phillips APD-3500 instrument. Bulk samples consist mainly of quartz, feldspar, calcite, dolomite, micas, and clay minerals. Estimates of percentage abundance of the minerals (table 5) were made by measuring peak areas of the $4.25-\AA$ mica plus clay minerals, $3.36-\AA$ quartz, $3.25-\AA$ potassium feldspar, $3.20-\AA$ plagioclase, $3.03-\AA$ calcite, and $2.88-\AA$ dolomite diffractogram peaks and by using the weighting factors of Schultz (1964). In order to correct for the 3.36-A illite peak that overlaps that of quartz, the $10-\AA$ illite peak was calculated and subtracted from that of the 3.36- $\AA$ peak because 10 - $\AA$ and 3.36 - $\AA$ illite peaks occur in roughly equal proportions (ASTM card 9-334).
Composition of the clay-size $(<0.005-\mathrm{mm})$ fraction of samples, separated from bulk samples by centrifuging, was also determined by X-ray diffraction analysis of untreated and glycolated samples using a scanning speed of $1^{\circ} 20^{\prime}$ per minute. To differentiate chlorite and kaolinite, slow scans $\left(0.20^{\circ} 20^{\prime}\right.$ per minute) were run over the range $24^{\circ}$ to $26^{\circ} 20^{\prime}$ (3.5- $\AA$ peak) (Biscayne, 1965). This fraction consists of smectite, kaolinite, and chlorite with traces of quartz, feldspar, and calcite. X-ray patterns of some samples indicate the presence of a small amount of mixedlayer illite/smectite or smectite/vermiculite. For comparative purposes, the relative abundances of the major clay minerals were determined by measuring and applying weighting factors to the following peak areas (peak height multiplied by peak width at half height) on the glycolated 
pattern: The $17-\AA$ smectite peak; four times the $10-\AA \AA$ illite peak; and twice the $7-\AA$ kaolinite plus chlorite peak (Biscayne, 1965) (table 6). The kaolinite/chlorite ratio was determined by measuring areas of the $3.54-\AA$ chlorite and 3.58 - $\AA$ kaolinite peaks on the slow-scan diffractogram and apportioning the ratio to the $7-\AA$ peak area (Biscayne, 1964). The four weighted peak areas were summed, and each is expressed as a percentage of the total, as 100 percent clay minerals.

In that part of southern Qinghai-Xizang (Tibet) Plateau (figs. 2 and 3 ) where samples 1 through 17 were collected, east-trending belts of Mesozoic sedimentary rocks make up the bulk of potential source rocks for sediment samples in the area. An east-trending belt of plutonic rocks occurs to the north, and a belt of ophiolitic rocks occurs close to many of the sampling sites in the center of the mapped area (fig. 34A).
Composition of the sand-size fraction of the sediments, particularly varieties of lithic fragments that were identified (table 4), can be used as a rough indicator of sediment sources. However, direct comparisons of sandfraction petrology cannot be made because the data also reflect variations in composition due to grain-size variations among the sand fractions analyzed (see Slatt and Eyles, 1981, for a discussion of variations in composition of glacially derived sands of different grain size; also see Péwé and Journaux, 1983, for a discussion of mineralogical differences that do not reflect size fractions of loess in Siberia). For example, samples 6 and 7 contain an abundance of igneous lithic fragments (table 4) that are of coarse-sand size. Most other samples contain only finesand-sized particles, which are enriched in quartz, shale, and carbonate lithic fragments. Although these sands may have had a plutonic or volcanic source, such fragments

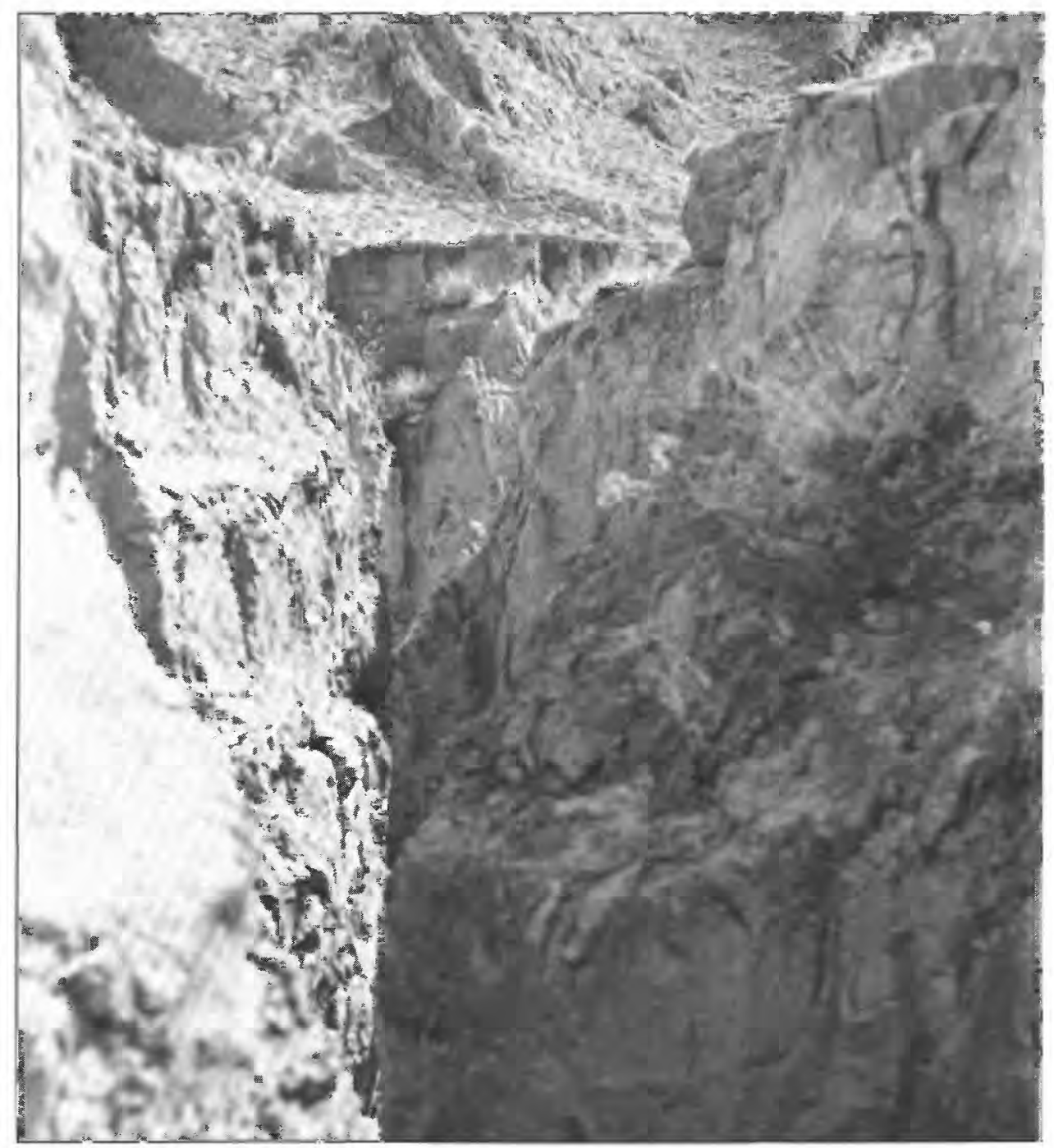

Figure 23. Deep, sharp-walled gully $3 \mathrm{~m}$ wide at top, dissected into retransported loess fan at base of limestone knob $50 \mathrm{~km}$ downstream from Xigaze on the Yarlung Zangbo, Xizang Autonomous Region, China. View east of collection site 4 (table 1). Photograph PK 23,905 by Troy L. Péwé, June 9, 1980. 
Table 3. Percentage of sand, silt, and clay in sand and loesslikesilt samples from southern Qinghai-Xizang (Tibet) Plateau, China, and loess from Beijing, China.

[U.S. Department of Agriculture classification: sand, $1.0-0.05 \mathrm{~mm}$; silt 0.05-0.005 mm; clay, $0.005-0.002 \mathrm{~mm}$. See table 1 for sampling information.]

\begin{tabular}{|c|c|c|c|c|c|}
\hline $\begin{array}{l}\text { Sample } \\
\text { No. }\end{array}$ & Material & Sand & Silt & Clay & Total \\
\hline 1 & $\begin{array}{l}\text { Retransported sandy } \\
\text { loess. }\end{array}$ & 36.5 & 47.2 & 16.3 & 100.0 \\
\hline 2 & 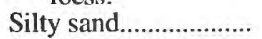 & 57.5 & 25.5 & 17.0 & 100.0 \\
\hline 3 & Sandy loess...................... & 43.0 & 54.5 & 2.5 & 100.0 \\
\hline 4 & Sandy loess..................... & 55.0 & 34.4 & 10.6 & 100.0 \\
\hline 5 & Retransported loess... & 8.5 & 36.8 & 54.7 & 100.0 \\
\hline 6 & Retransported loess... & 19.2 & 75.3 & 5.5 & 100.0 \\
\hline 7 & Retransported loess... & 3.8 & 40.2 & 56.0 & 100.0 \\
\hline 8 & Retransported loess... & 2.5 & 50.2 & 47.3 & 100.0 \\
\hline 9 & $\begin{array}{l}\text { Silty pebbly retrans- } \\
\text { ported loess. }\end{array}$ & 11.5 & 53.5 & 35.0 & 100.0 \\
\hline 10 & Eolian sand.................... & 82.5 & 10.3 & 7.2 & 100.0 \\
\hline 11 & Retransported loess... & 20.0 & 50.0 & 30.0 & 100.0 \\
\hline 12 & $\begin{array}{l}\text { Silty } \\
\text { sand........................ }\end{array}$ & 80.0 & 13.5 & 6.5 & 100.0 \\
\hline 13 & Retransported loess... & 9.0 & 48.5 & 41.5 & 100.0 \\
\hline 14 & Retransported loess... & 30.5 & 28.0 & 40.5 & 100.0 \\
\hline 15 & Retransported loess... & 16.0 & 18.5 & 64.5 & 100.0 \\
\hline 16 & $\begin{array}{l}\text { Retransported loess } \\
\text { and sandy loess. }\end{array}$ & 37.0 & 21.5 & 41.5 & 100.0 \\
\hline 17 & Crossbedded sand....... & 99.0 & 1.0 & .0 & 100.0 \\
\hline 18 & Retransported loess... & 3.2 & 51.6 & 21.5 & 100.0 \\
\hline 19 & $\begin{array}{l}\text { Retransported } \\
\text { gravelly loess }{ }^{1} \text {. }\end{array}$ & 20.0 & 58.5 & 21.5 & 100.0 \\
\hline 20 & $\begin{array}{l}\text { Loess, Beijing, } \\
\text { China. }\end{array}$ & 25.0 & 49.5 & 25.5 & 100.0 \\
\hline
\end{tabular}

\footnotetext{
${ }^{1}$ Original sample included about 15 percent gravel larger than $2 \mathrm{~mm}$, which was removed before this analysis.
}

would not be fine-sand-sized particles. To compare compositions of the ten sands accurately, only one sand-size fraction should have been studied petrographically: however, in most instances insufficient material was available to make such a fractionation. In addition, only a few sand samples contain any coarse sand, which is the most valuable fraction for recognizing lithic fragments.

Nevertheless, the data in table 4 show that a wide variety of rocks contributed to the sediments. Samples 6 and 7 are rich in mafic plutonic and volcanic lithic fragments, probably derived from ophiolite terrane. Enrichment of sample 10 in felsic plutonic fragments, as well as in feldspar, indicates derivation from the nearby plutonic terrane. Samples 4, 5, and 8 are enriched in carbonate lithic fragments, which could have been derived from the same sequences. The lithic fragments in samples 1 to 10 do not suggest a major plutonic source; however, much of the quartz could have such a derivation. Most quartz grains are angular, suggesting that they are first-cycle detritus; however, samples enriched in carbonate lithic fragments also contain a high proportion of multicycle rounded quartz grains. The high proportion of sand-size chlorite in samples 1,2 , and 7 probably reflects derivation from mafic ophiolitic rocks.

Composition of the clay-size fraction of the sediments (table 6) can be used to compare probable sediment sources. Relative proportions of the clay minerals are presented in figure $34 B$. Samples $1,2,7$, and 10 contain the highest proportion of smectite, and samples 1 and 7 contain the highest proportions of chlorite; these proportions indicate at least partial derivation from mafic ophiolitic rocks. The site of sample 9, which has the lowest chlorite content, is farthest from the ophiolite terrane (fig. 34A).

Table 4. Mineral composition of sand-size $(>0.062-\mathrm{mm})$ fraction of sand and loesslike silt from southern Qinghai-Xizang (Tibet) Plateau, China

[Calculations in weight percent. Heavy minerals include mainly amphiboles, pyroxenes, and opaque minerals. Tr, trace; -, not detected. Petrographic analyses by Cities Service Company, Tulsa, Okla. Samples collected by T.L. Péwé unless otherwise noted. See table 1 and figures 3, 27, and 34 for sampling sites.]

Lithic fragments

\begin{tabular}{|c|c|c|c|c|c|c|c|c|c|c|c|c|c|c|c|c|}
\hline \multirow{3}{*}{$\begin{array}{c}\text { Sample } \\
\text { No. }\end{array}$} & \multirow{2}{*}{\multicolumn{2}{|c|}{ Quartz }} & \multirow{2}{*}{\multicolumn{3}{|c|}{ Feldspar }} & & & & & & & & \multirow{3}{*}{ 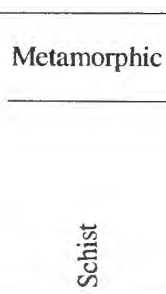 } & \multirow{2}{*}{\multicolumn{2}{|c|}{ Micas }} & \multirow{3}{*}{$\begin{array}{c}\text { Heavy } \\
\text { minerals }\end{array}$} \\
\hline & & & & & & \multicolumn{3}{|c|}{ Igneous } & \multicolumn{4}{|c|}{ Sedimentary } & & & & \\
\hline & 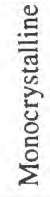 & 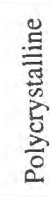 & $\begin{array}{l}\text { U: } \\
\frac{0}{U} \\
0 \\
\frac{0}{E} \\
0\end{array}$ & $\begin{array}{l}\frac{8}{0} \\
\frac{\pi}{0} \\
\frac{0}{60} \\
\frac{\pi}{0} \\
\frac{\pi}{0}\end{array}$ & 总 & 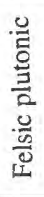 & 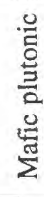 & 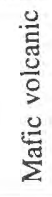 & 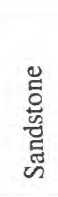 & 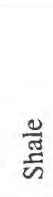 & 莺 & 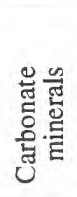 & & 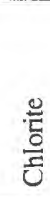 & 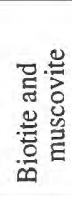 & \\
\hline 1 & 35 & 7 & 3 & 3 & - & - & - & $\operatorname{Tr}$ & 1 & 24 & - & 3 & - & 14 & 5 & 5 \\
\hline 2 & 43 & 9 & 1 & 2 & $\mathrm{Tr}$ & - & - & $\mathrm{Tr}$ & - & 4 & I & 2 & - & 30 & 2 & 6 \\
\hline 3 & 57 & 17 & 1 & 4 & 2 & - & . & - & - & - & $\operatorname{Tr}$ & - & - & 8 & 2 & 9 \\
\hline 4 & 43 & 7 & 5 & - & - & - & - & - & 2 & 1 & - & 36 & 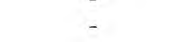 & 2 & 2 & 2 \\
\hline 5 & 21 & 8 & 1 & 1 & 2 & - & - & - & 5 & 3 & 2 & 53 & - & 2 & 2 & $\mathrm{Tr}$ \\
\hline 6 & 15 & 4 & - & 2 & $\operatorname{Tr}$ & 2 & 22 & 37 & - & 6 & - & 1 & - & 7 & $\mathrm{Tr}$ & 4 \\
\hline 7 & 26 & 14 & $\operatorname{Tr}$ & 3 & $\mathrm{Tr}$ & 1 & 4 & 29 & . & 3 & 3 & $\mathrm{Tr}$ & $\operatorname{Tr}$ & 14 & 1 & 2 \\
\hline 8 & 33 & 20 & 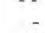 & 1 & - & - & - & 7 & $\operatorname{Tr}$ & 7 & 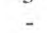 & 14 & 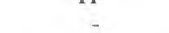 & 3 & 3 & 11 \\
\hline 9 & 40 & 22 & 2 & 2 & - & - & - & $\mathrm{Tr}$ & - & 4 & 7 & 2 & 4 & $\mathrm{Tr}$ & 6 & 10 \\
\hline $10^{1}$ & 47 & 7 & 4 & $\tilde{6}$ & 3 & 9 & . & $\mathrm{Tr}$ & 1 & 4 & $\mathrm{Tr}$ & 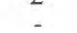 & 1 & 3 & 8 & 7 \\
\hline
\end{tabular}


Table 5. Mineral composition of bulk samples of sand and loesslike silt from southern Qinghai-Xizang (Tibet) Plateau, China (Nos. 110 ), and from Heidelberg, Germany.

[Calculations in weight percent; -, not detected. X-ray diffraction analyses by Cities Service Company, Tulsa, Okla. Samples collected by T.L Péwé unless otherwise noted. See table 1 and figures 3,27, and 34 for sampling sites.]

$\begin{array}{ccc}\begin{array}{c}\text { Sample } \\ \text { No. }\end{array} \quad \text { Quartz } & \begin{array}{c}\text { Potassium } \\ \text { feldspar }\end{array} & \begin{array}{c}\text { Plagio- } \\ \text { clase }\end{array}\end{array}$ Calcite Dolomite $\begin{gathered}\text { Micas and } \\ \text { clay minerals }\end{gathered}$

\begin{tabular}{lrrrrrl}
\hline 1 & 33 & - & 11 & 2 & 3 & 51 \\
2 & 44 & 9 & 8 & 5 & 3 & 31 \\
3 & 32 & 1 & 9 & 7 & 11 & 40 \\
4 & 29 & 6 & 25 & 7 & 1 & 32 \\
5 & 31 & 6 & - & 17 & 1 & 45 \\
6 & 35 & 10 & 13 & 6 & - & 36 \\
7 & 30 & - & 8 & 2 & - & 60 \\
8 & 34 & 1 & 5 & 4 & 1 & 55 \\
9 & 18 & 2 & 8 & 53 & - & 19 \\
$10^{1}$ & 33 & 22 & 29 & - & - & 16 \\
Germany & 29 & 3 & 6 & 27 & 32 & 14 \\
\hline
\end{tabular}

${ }^{1}$ Collected by Liu Tungsheng and Li Bingyuan.
Table 6. Mineral composition by weighted peak-area percentages of clay-size $(<0.005-\mathrm{mm})$ fraction of sand and loesslike silt from southern Qinghai-Xizang (Tibet) Plateau, China.

[Calculations in weight percent. Tr, trace; -, not detected. X-ray diffraction analyses by Cities Service Company, Tulsa, Okla. Samples collected by T.L Péwé unless otherwise noted. See table 1 and figures 3,27, and 34 for sampling sites.]

Sample Smectite Illite Kaolinite Chlorite Quartz Feldspar Calcite No.

\begin{tabular}{rrrrrrrr}
1 & 9 & 48 & 18 & 25 & $\operatorname{Tr}$ & $\operatorname{Tr}$ & - \\
2 & 16 & 57 & 15 & 11 & $\operatorname{Tr}$ & $\operatorname{Tr}$ & - \\
3 & - & 77 & 7 & 16 & $\operatorname{Tr}$ & $\operatorname{Tr}$ & - \\
4 & - & 69 & 10 & 21 & $\operatorname{Tr}$ & $\operatorname{Tr}$ & - \\
5 & - & 77 & 9 & 14 & $\operatorname{Tr}$ & $\operatorname{Tr}$ & - \\
6 & $\operatorname{Tr}$ & 81 & - & 19 & $\operatorname{Tr}$ & $\operatorname{Tr}$ & - \\
7 & 5 & 68 & - & 27 & $\operatorname{Tr}$ & $\operatorname{Tr}$ & - \\
8 & - & 86 & - & 14 & $\operatorname{Tr}$ & $\operatorname{Tr}$ & $\operatorname{Tr}$ \\
9 & - & 92 & 3 & 5 & $\operatorname{Tr}$ & $\operatorname{Tr}$ & $\operatorname{Tr}$ \\
$10^{1}$ & 8 & 64 & 7 & 21 & $\operatorname{Tr}$ & $\operatorname{Tr}$ & - \\
\hline
\end{tabular}

'Collected by Liu Tungsheng and Li Bingyuan.

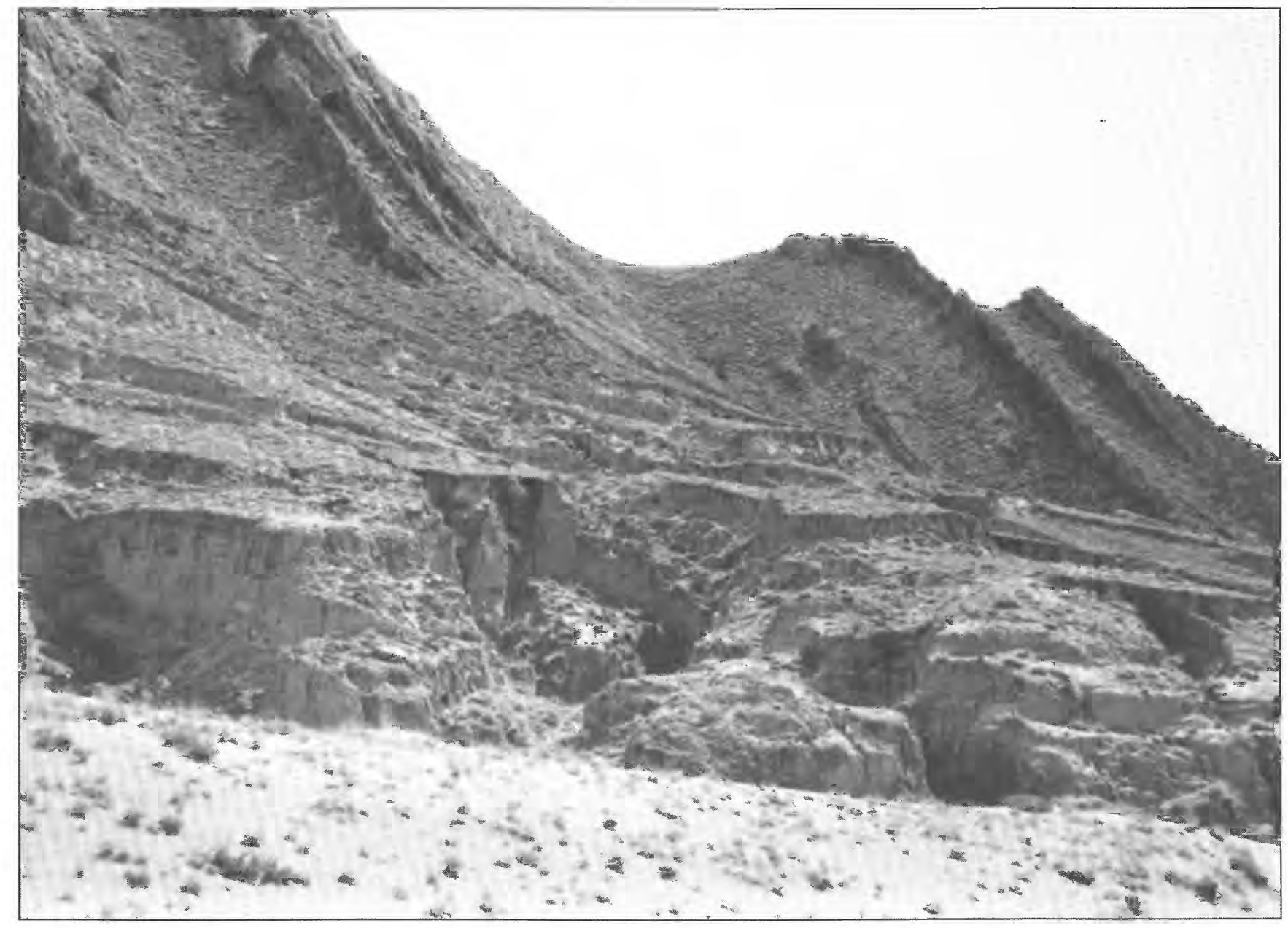

Figure 24. Alluvial fan of retransported loess sharply dissected by steep-walled gullies as much as $6 \mathrm{~m}$ deep. Fans flank limestone bedrock knob $50 \mathrm{~km}$ downstream from Xigaze on the Yarlung Zangbo, Xizang Autonomous Region, China. Photograph PK 23,904 by Troy L. Péwé, June 9, 1980. 


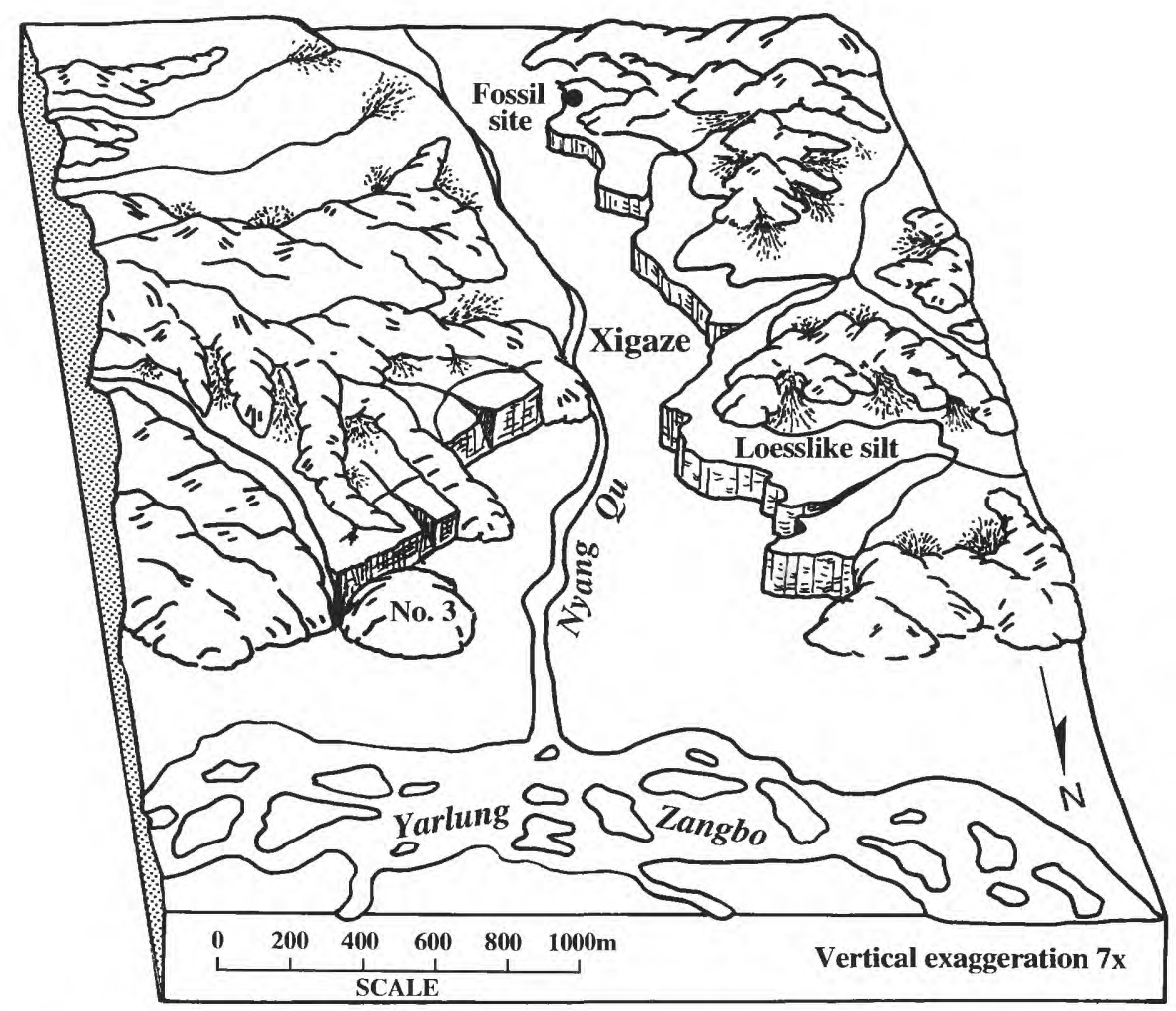

Figure 25. Physiographic diagram of Xigaze area at junction of Nyang Qu and Yarlung Zangbo, Xizang Autonomous Region, China. Terrace remnants of loesslike silt are about 15 $\mathrm{m}$ high. No. 3 is site of loess sample 3 (table 1; fig. 22), and "Fossil site" is a fossiliferous terrace (figs. 27, 37). Diagram by S.M. Selkirk from map prepared by Li Bingyuan.

Appreciable kaolinite is present in samples 1 to 5 and 10 and is absent in samples 6 to 8 to the west. This distribution indicates at least two different types of source rocks. It is possible that the kaolinite is derived from weathered rocks of the northern plutonic terrain, but it may also be a second-cycle kaolinite derived from sedimentary rocks.

Some information on source terrains can be gained by comparing the compositions of bulk-sediment samples (fig. 34C, table 5), although, like the sand fraction, bulk compositions are also affected by variations in grain-size distribution among the samples (fig. 29). Sample 9 is rich in calcite, which possibly suggests a local limestone source (Jurassic sediments) quite unlike that of other samples. The feldspar content tends to diminish in sediments from east to west, generally in sampling sites that are farther from the plutonic terrain (fig. 34A). Samples 4 and 10 , located closest to the plutonic terrain, contain the most feldspar (plagioclase is greater than orthoclase). Variations in the feldspar content probably reflect a variable supply of plutonic detritus to the sediments.

Combining the above compositional data for sand, clay-mineral, and bulk samples allows some generalizations about sediment sources and the extent of sediment transport. Samples 1, 2, 7, and possibly 6 have a strong source component of ophiolitic rocks. Samples 3, 4, 5, and 10 are at least partially derived from plutonic as well as Cretaceous sedimentary rocks (particularly carbonate rocks), and samples 8 and 9 are probably derived mainly from Triassic and Jurassic sedimentary rocks, respectively. Thus, although the sediments were originally of windblown origin and have subsequently been reworked, they have not been transported far enough to lose the compositional imprint of a fairly local origin.

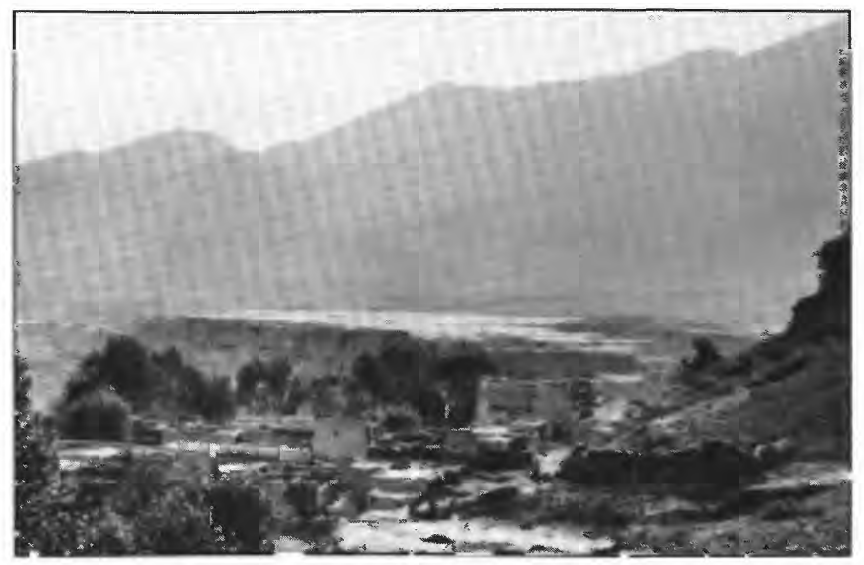

Figure 26. Flat-topped, steep-walled, 15-m-high remnant of bedded, vertically jointed retransported loess in bottom of Nyang $\mathrm{Qu}$ valley near its junction with Yarlung Zangbo on north side of Xigaze, Xizang Autonomous Region, China. View to southwest from bedrock knob near site of sample 3 (figs. 22, 25). Photograph PK 23,897 by Troy L. Péwé, June 9, 1980. 

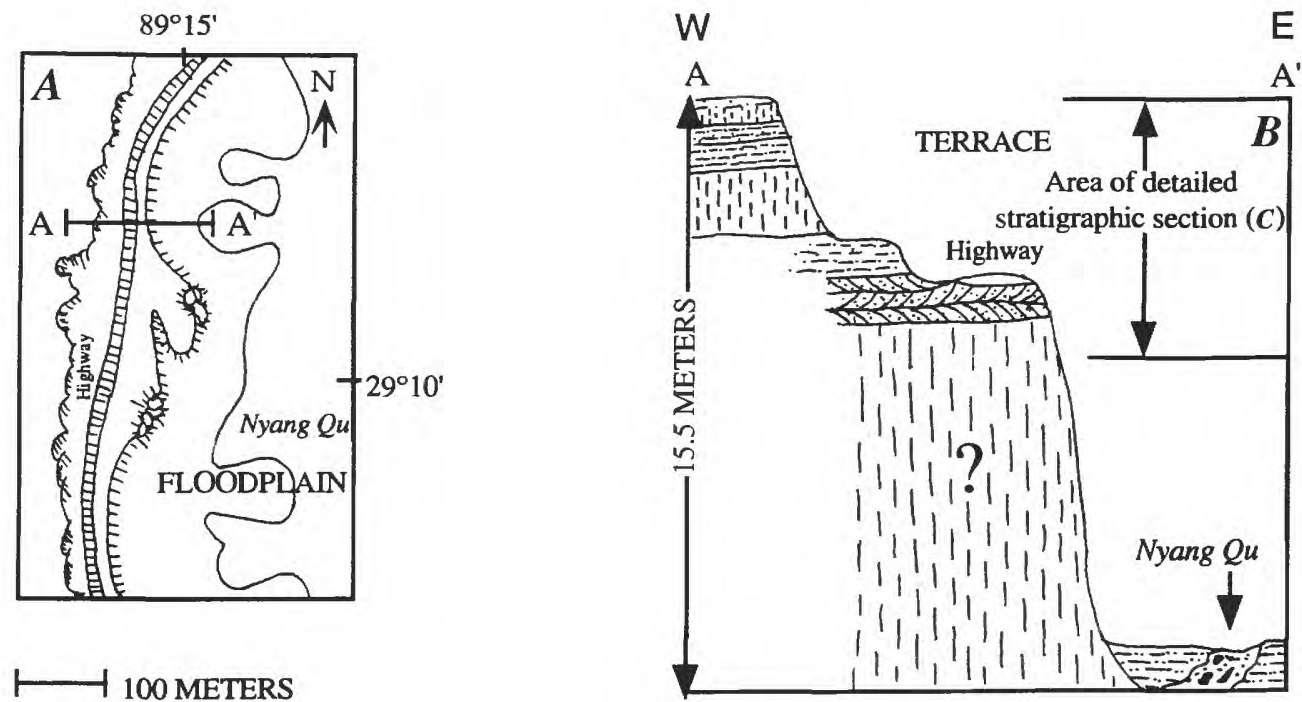

$\longmapsto 100$ METERS
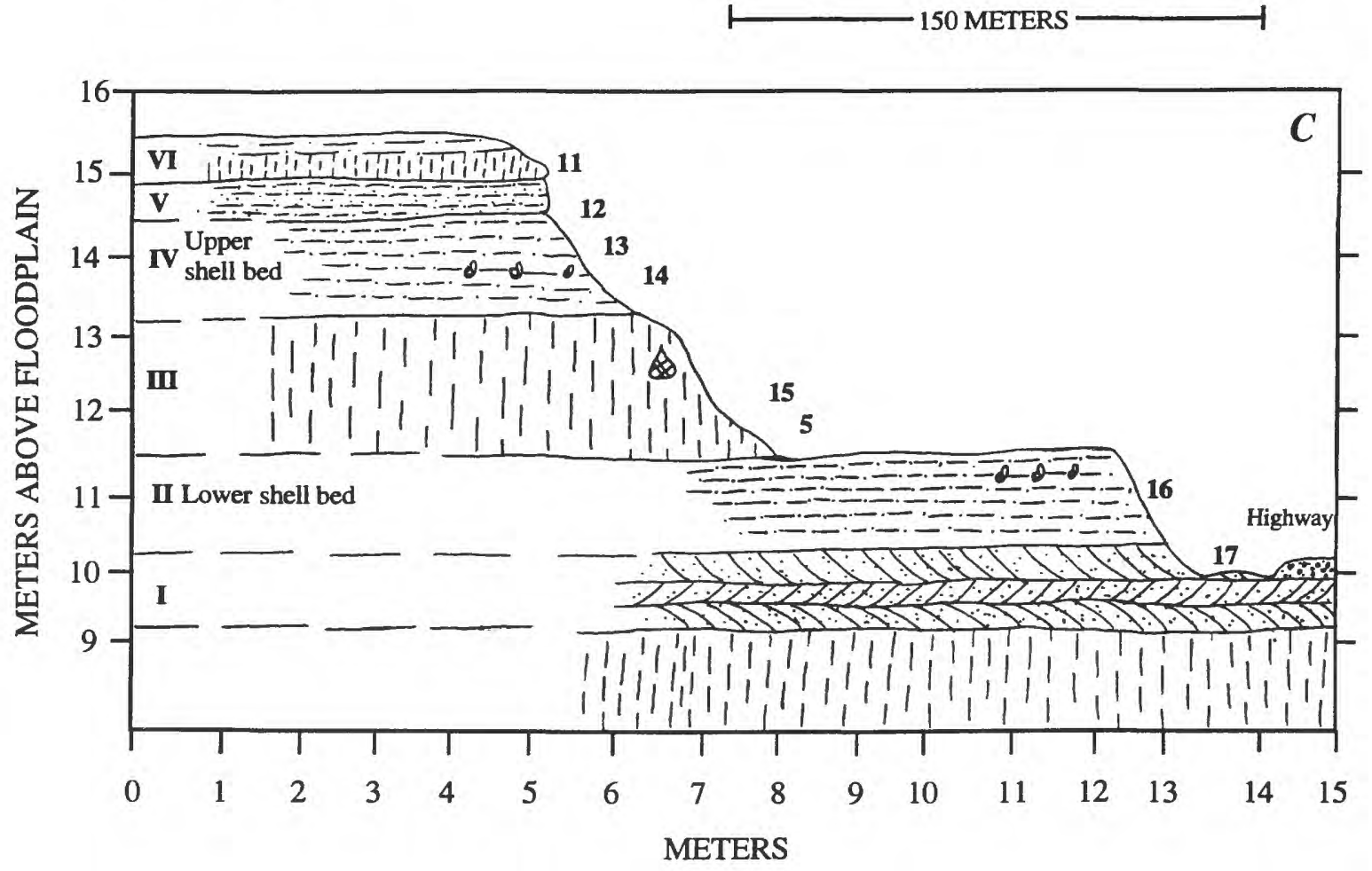

\section{EXPLANATION}

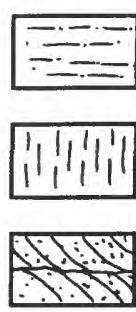

Fine sand, silt and silty clay (retransported loess and sandy loess)

Silt, and silty clay (retransported loess)

Coarse sand
Figure 27. Sketch map of flood plain and terraces $(A)$ and stratigraphic sections $(B, C)$ of retransported sandy loess, silty clay, and coarse sand cropping out on terrace scarp on west side of the Nyang Qu, south side of Xigaze, Xizang Autonomous Region, China. Note collection sites of sediment samples 11 to 17 (table 1) and of vertebrate and invertebrate fossils (see fig. 28). 


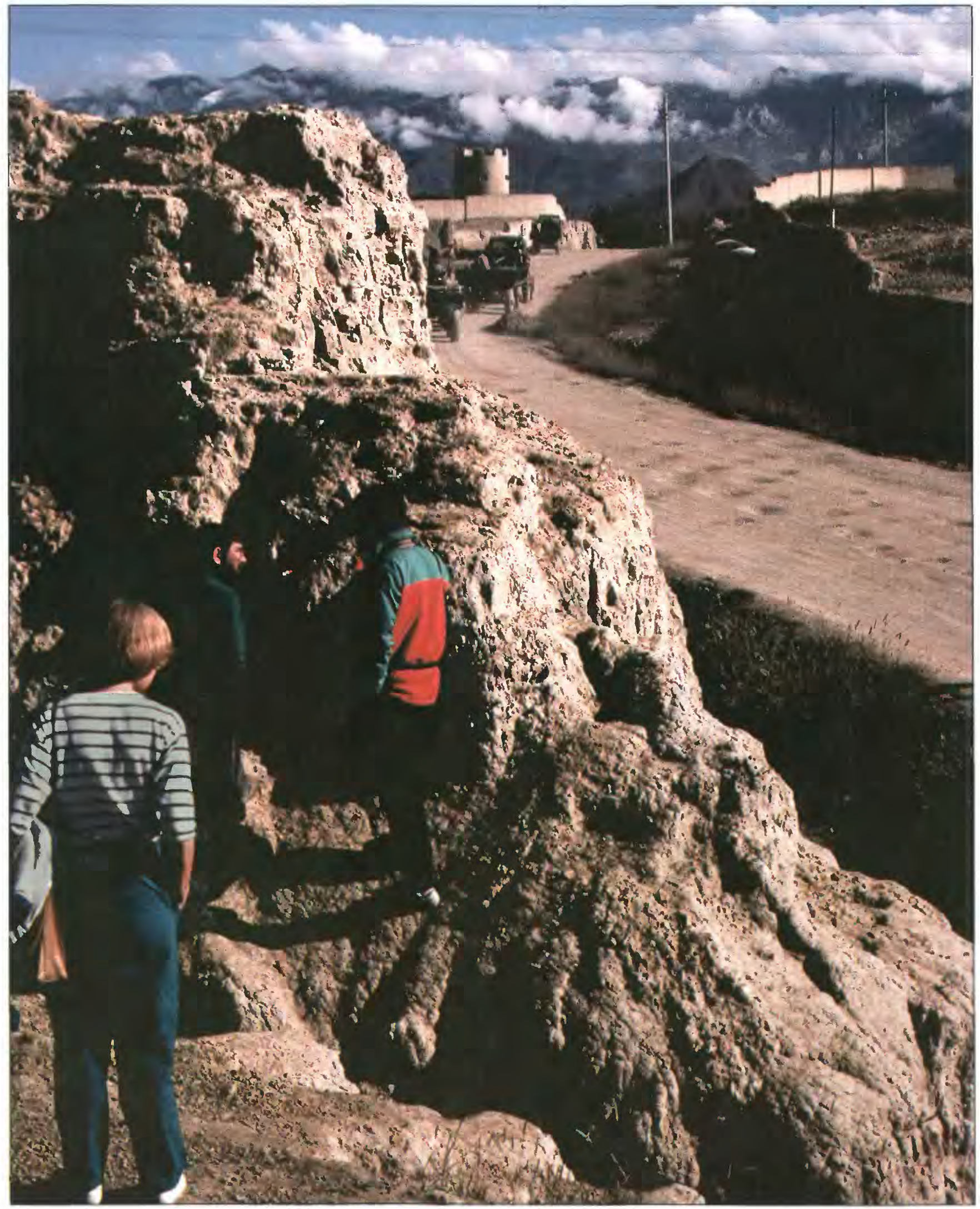

Figure 28. Cliff-forming retransported tan loess exposed in road cut near Army fuel station along Xigase-Lhasa Highway on south side of Xigaze, Xizang Autonomous Region, China. This classic section is site of bird fossils, thin layers of fresh-water mollusk shells near middle and lower part of the exposure, and numerous sediment and pollen samples (see figs. 27, 37). Note wall made of bricks of loess in upper right. Inspecting scientists are members of International Union of Quaternary Research (INQUA) field excursion. View toward northeast. Hills of clastic rocks of Cretaceous age in distance lie east of the Nyang Qu and south of the Yarlung Zangbo (figs. 25, 34A). Photograph PK 29,937 by Troy L. Péwé, August 20, 1991. 


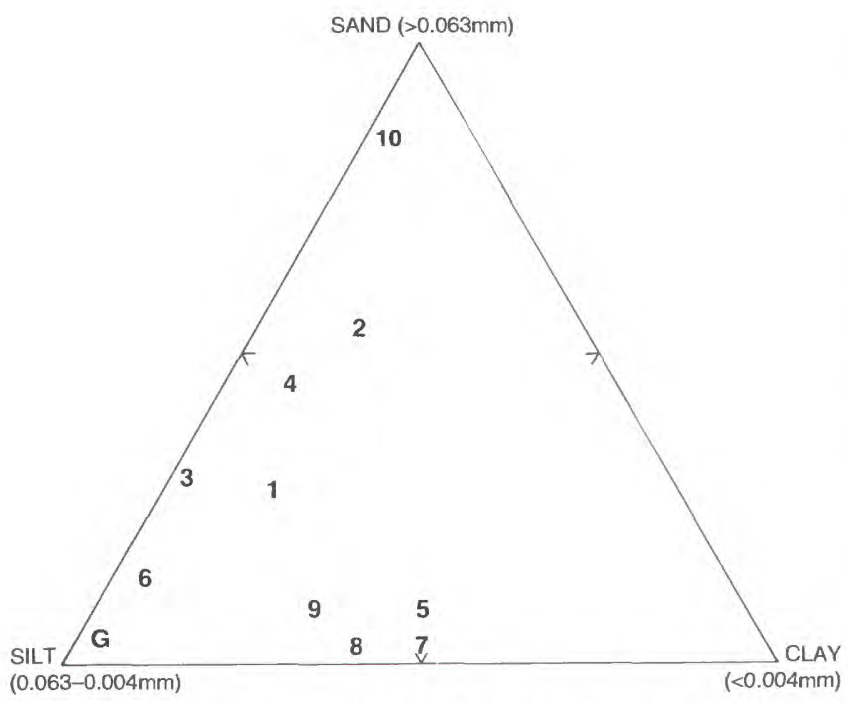

Figure 29. Proportions of sand, silt, and clay in sediment samples 1 to 10 from south-central Qinghai-Xizang (Tibet) Plateau, China, and a loess sample from Germany $(G)$. (See figs. 3 and 34 for sampling sites.) Diagram by S.M. Selkirk.

In order to verify that sediment samples have indeed been transported and not derived by in situ weathering, a bedrock sample was collected from beneath loess sample 3 (figs. 22, 34A) on top of a 15-m-high bedrock knob at the junction of Yarlung Zangbo and Nyang Qu at Xigaze (fig. 3). Petrographic analysis indicates the rock is a volcaniclastic sandstone or lithic tuff of basaltic or andesitic provenance, which has undergone considerable alteration under either hydrothermal or lowgrade regional-metamorphic conditions that resulted in the authigenic mineral assemblage of subgreenschist facies. The rock consists mostly of altered mafic to intermediate volcanic-rock fragments and plagioclase. Volcanic glass fragments are altered to quartz and pumpellyite and lined with chlorite and sphene. Most of the quartz is authigenic, primary plagioclase is changed to albite, and chlorite and pumpellyite partially replace plagioclase. Results of X-ray-diffraction analyses of wholerock and clay-mineral fractions of sample 3 (figs. 35A, $B$ ) are compared with those of the underlying bedrock (fig $35 B, D$ ). Analysis of sample 3 shows that the loess at that location is not derived from the underlying bedrock because (1) pumpellyite is present in the bedrock but absent in the sediment and (2) illite is present in the sediment but absent in the bedrock.

\section{FIELD RELATIONS}

Where the loesslike silt has been transported by fluvial or colluvial processes or is in an original position of deposition on top of a low hill next to a river (as in fig. 22), it overlies various substrates with a sharp contact.
Only on local hilltops is the silt massive, showing little or no stratification or jointing. Most of the loesslike silt has been retransported to lower slopes, alluvial fans, or valley bottoms, where it is thickest (figs. 21, 25, 26) and shows poorly to well-developed stratification. The stratification varies from iron-stained horizons, organic films, and color banding to well-developed sand-and-gravel layers 10 to $200 \mathrm{~cm}$ thick in sharp contact with the silt beds. Nowhere does the stratification resemble lacustrine bedding. No tephra layers are known in the loesslike silt, and no major soil horizons, such as are widely reported in central China (Liu and Chang, 1964; Liu and others, 1964, 1966; Liu and Wang, 1965; Liu and others, 1985; Liu, 1991; Rutter and others, 1991), were observed.

A conspicuous feature of the loesslike silt is its ability to stand in sheer cliffs (figs. 26, 27, 28). This characteristic is probably due to the angularity of the grains and to the strengthening by concretionary rods and tubes. This well-developed vertical cleavage of loess in China has been discussed from the beginning of the 20th century and attributed to vertical permeability by Willis (Willis and others, 1907) and to carbonate deposits around plant roots by Barbour (1925a, b). As in the loess elsewhere in China, vertical walls 10 to $15 \mathrm{~m}$ high in the valley-bottom facies of the loesslike silt at Xigaze have stood for many years. Jointing is not common, but vertical jointing typical of loess is well displayed in cliffs at Xigaze (fig. 28). Sharp, steep-walled gullies form in the loesslike silt and are most common on fans (figs. 17, 18, 23, 24).

\section{FOSSILS IN LOESSLIKE SILT}

Loess and retransported loess from many countries have long been known as excellent material for preserving Quaternary fossils: Vertebrates, mainly mammals, including frozen carcasses; invertebrates such as freshwater and pulmonate mollusca, insects; and flora, pollen and mega-specimens. Fossils in the classic loess areas of north-central and eastern China are widespread and include pollen, insects, ostracodes, mammals, birds (especially large ostrich eggs) and hominids. Fossils in the loess of China have been known to the western world since the days of von Richthofen's work in the 1870's and from later studies (von Richthofen, 1877, 1882; Andersson, 1923; Barbour, 1925a, b, 1930; Liu and others, 1964, 1966; Liu, 1985; Chen and others, 1985; Xue, 1984).

Reports of Quaternary fossils from the loesslike silt of the plateau are sparse, but observations are known from about the 1950's (Huang, 1980; Huang and Ji, 1981; Péwé, 1980a, b; Wang and $\mathrm{Li}, 1983$ ). One of the most thoroughly studied fossil-bearing sections of loesslike silt in the plateau is a 6$\mathrm{m}$ section exposed along the highway on the south side of Xigaze (figs. 27, 28). In 1980, Péwé, Liu, and Li, assisted by several scientists, collected sediment samples, fossils of 


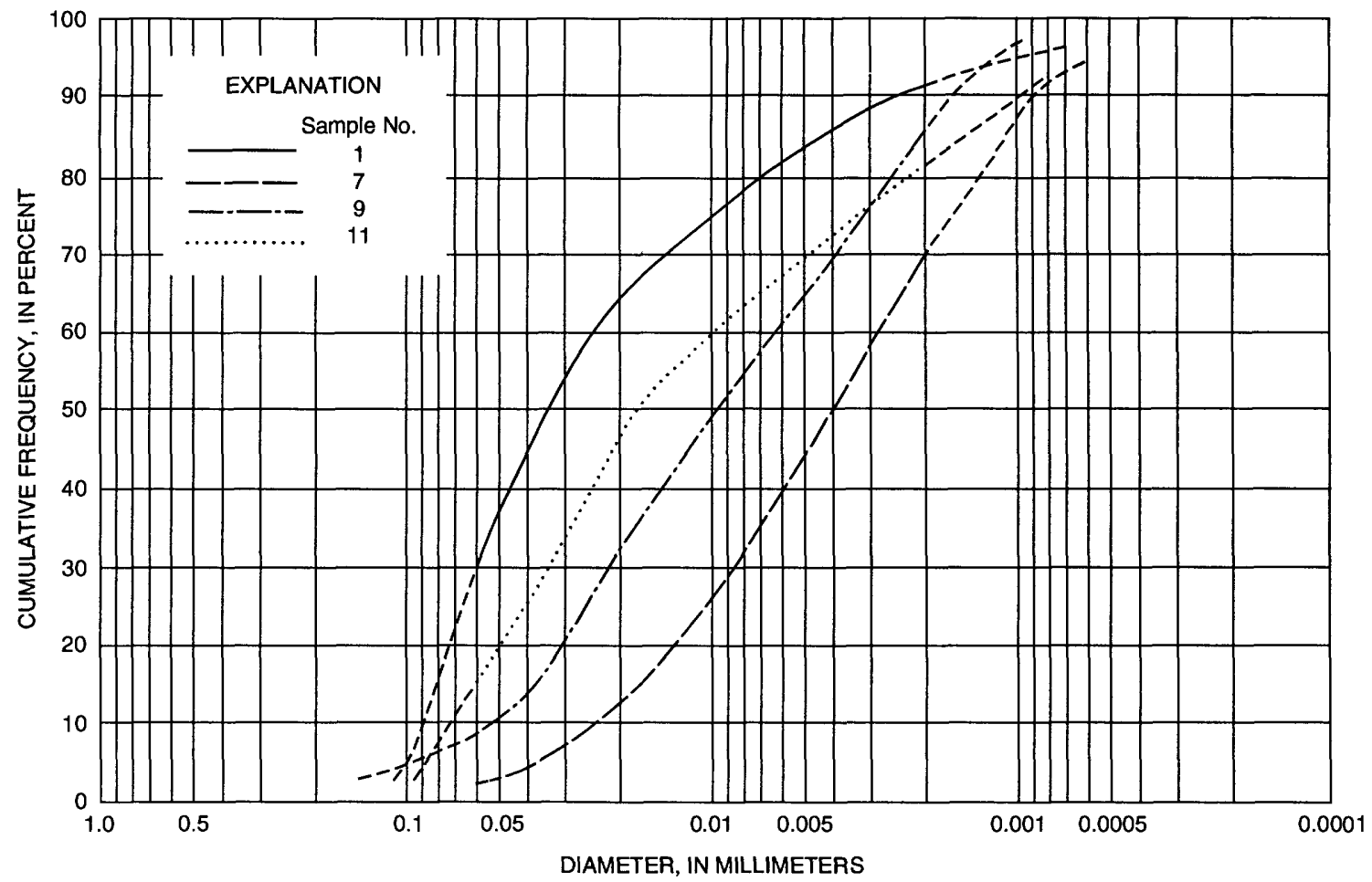

Figure 30. Cumulative-frequency grain-size curves (short dashes where projected) for retransported loesslike silt in southern part of Qinghai-Xizang (Tibet) Plateau, China. Clay-size grains have been incorporated during retransportation, so curves are not typical of those for primary loess. (See figs. 3 and 34 for sampling sites.)

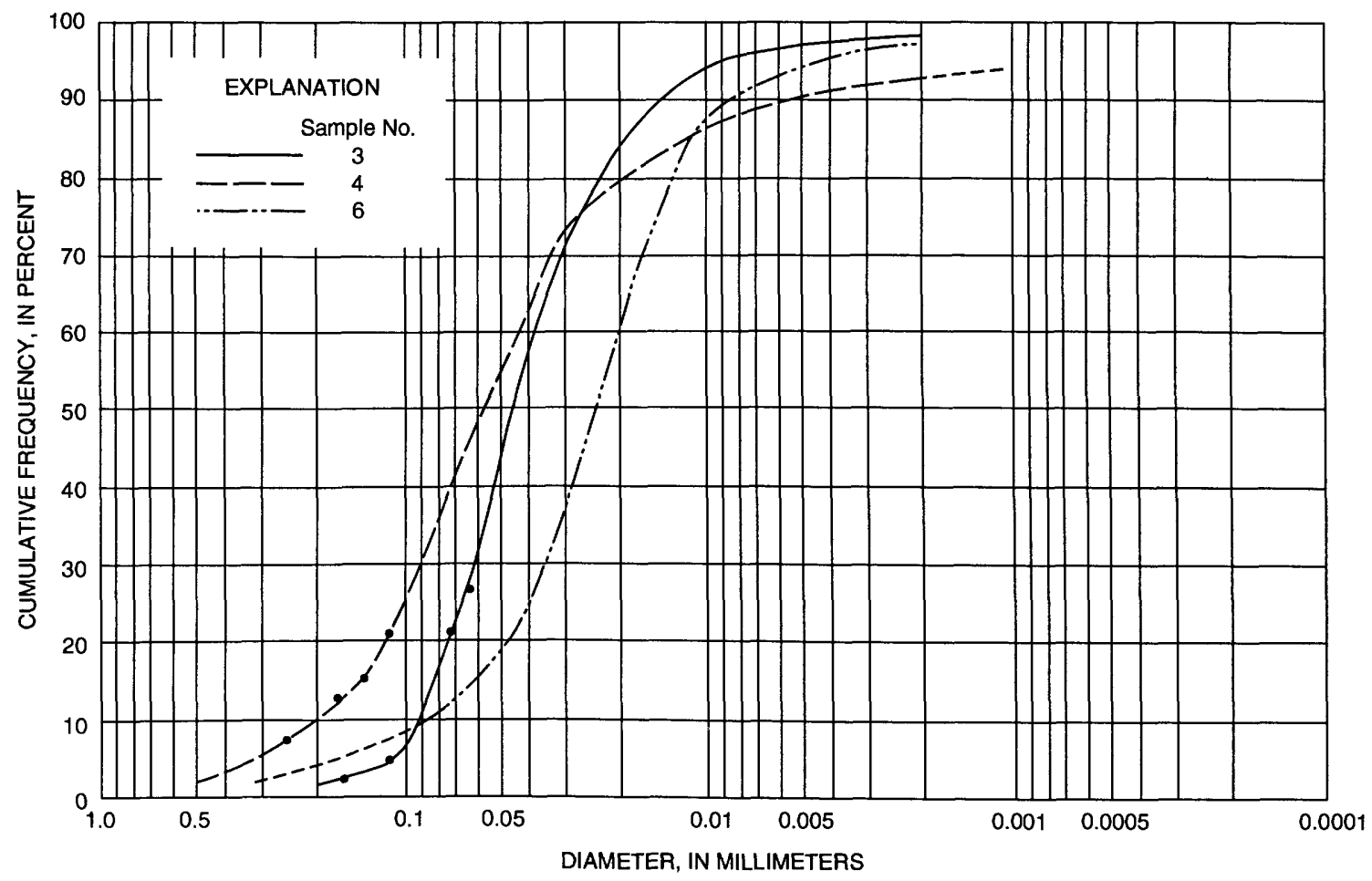

Figure 31. Cumulative-frequency grain-size curves (short dashed where projected) for samples of loess flanking or on top of bedrock knobs near the Yarlung Zangbo (Nos. 3, 4) and loesslike silt (No. 6) in agricul- tural field near toe of low-angle silt fan, Xizang Autonomous Region, China. Curves are similar to those of primary loess. Dots are data points. (See figs. 3 and 34 for sampling sites.) 


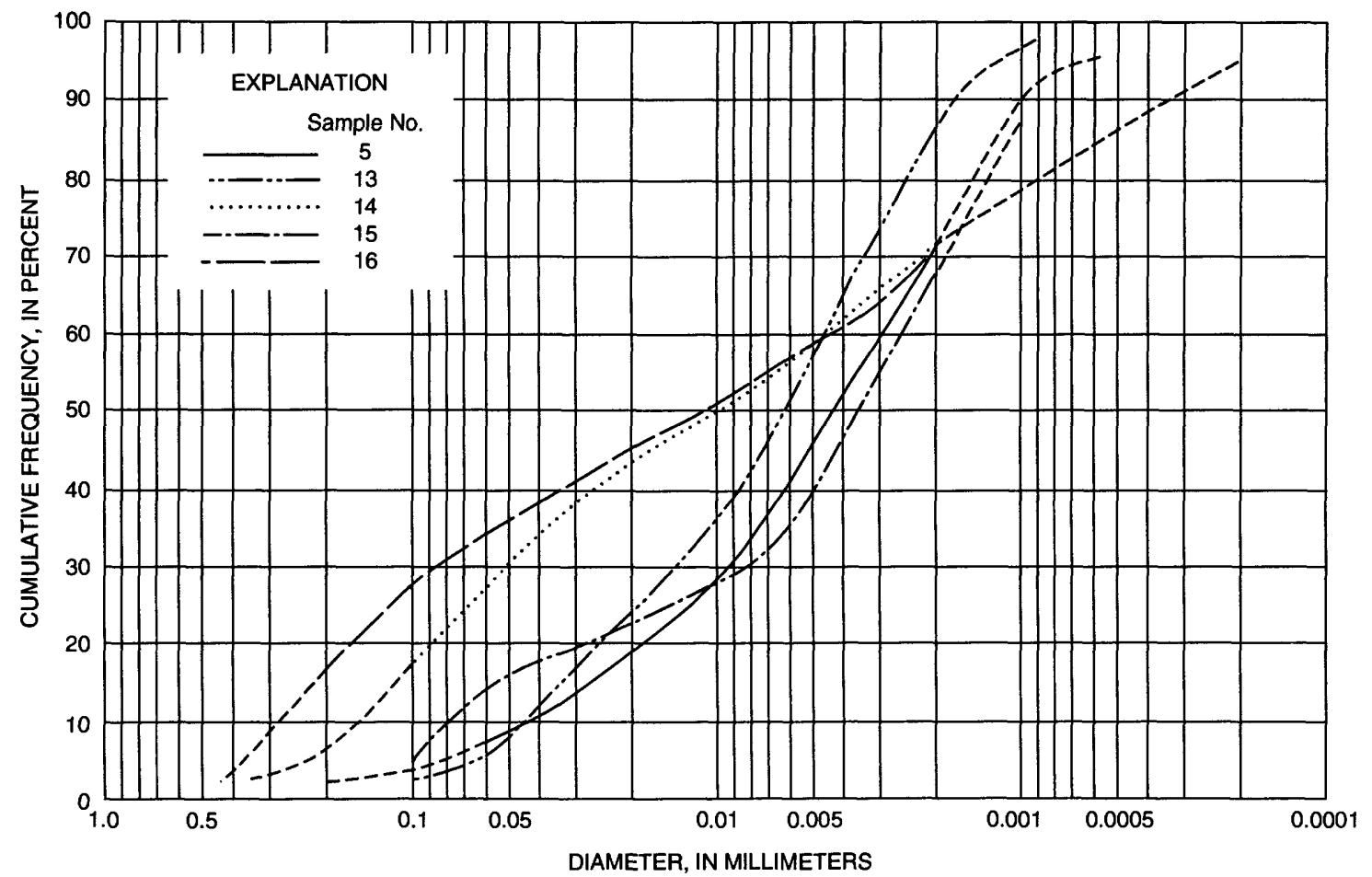

Figure 32. Cumulative-frequency grain-size curves (short dashed where projected) for clay-rich retransported loess, south-central Qinghai-Xizang (Tibet) Plateau, China. Many clay-sized grains have been incorporated during fluvial retransportation. (See figs. 3 and 34 for sampling sites.)

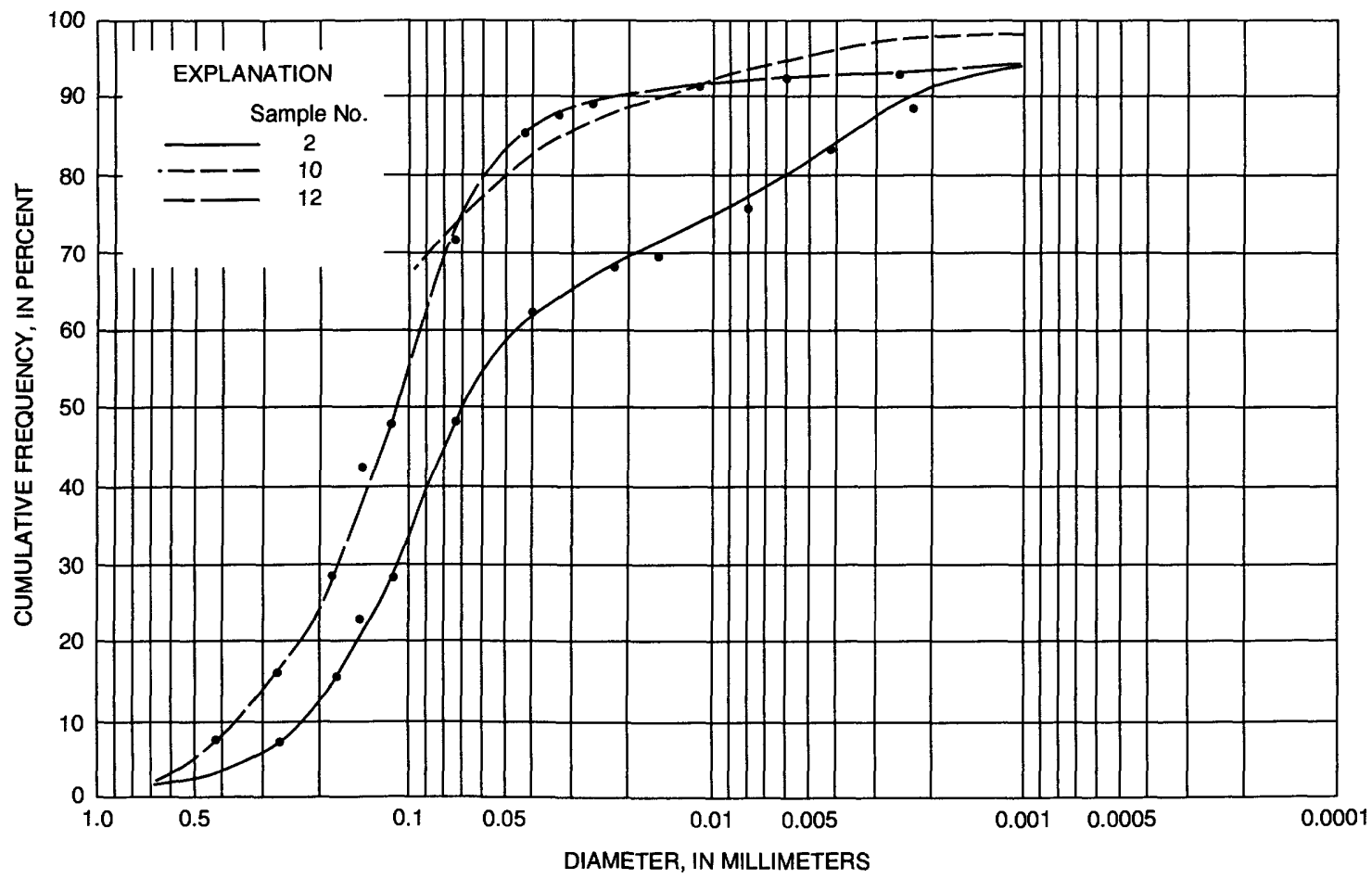

Figure 33. Cumulative-frequency grain-size curves for samples of eolian (No. 10) and fluvial (Nos. 2, 12) sand, south-central Qinghai-Xizang (Tibet) Plateau, China. Dots are data points. (See figs. 3 and 34 for sampling sites.) 
mollusca, mammals, and birds, and samples for study of pollen and ostracodes from this site. In 1991, Péwé led participants of the Qinghai-Xizang (Tibet) Plateau field trip of the 13th Congress of International Union for Quaternary Research (INQUA) to this site, and many of the scientists collected mollusca fossils.

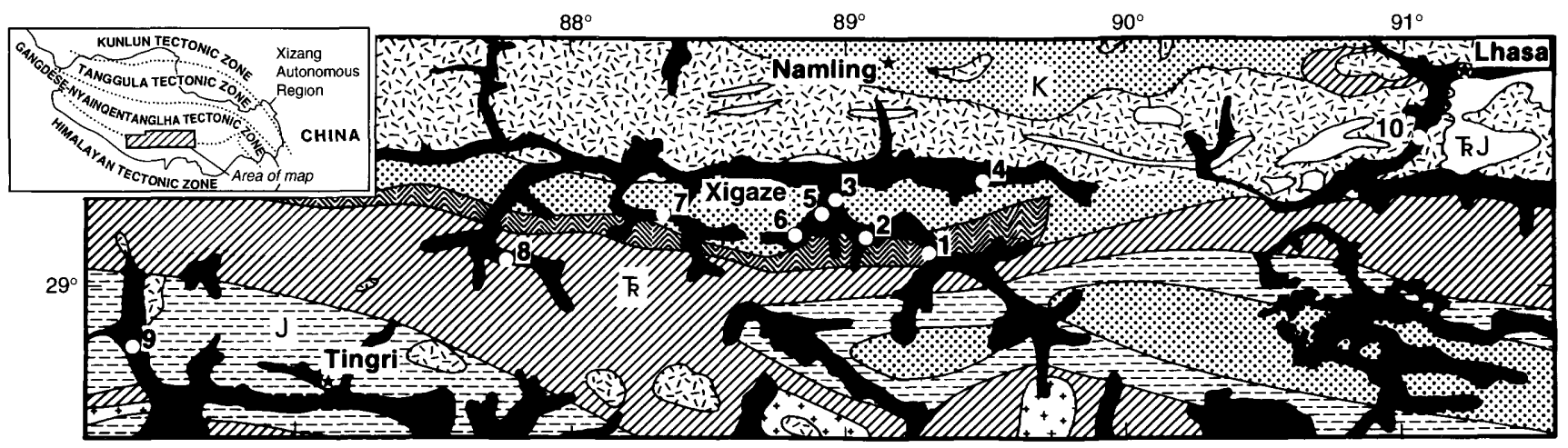

A

0

60 KILOMETERS

\section{EXPLANATION}

Quaternary fluvial and glacial sediments

Cretaceous sedimentary rocks

-J] Jurassic sedimentary rocks

U Undivided Triassic and Jurassic sandstones, shales, and limestones
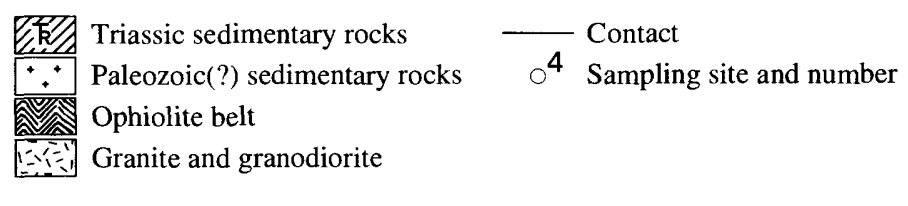

4 Sampling site and number
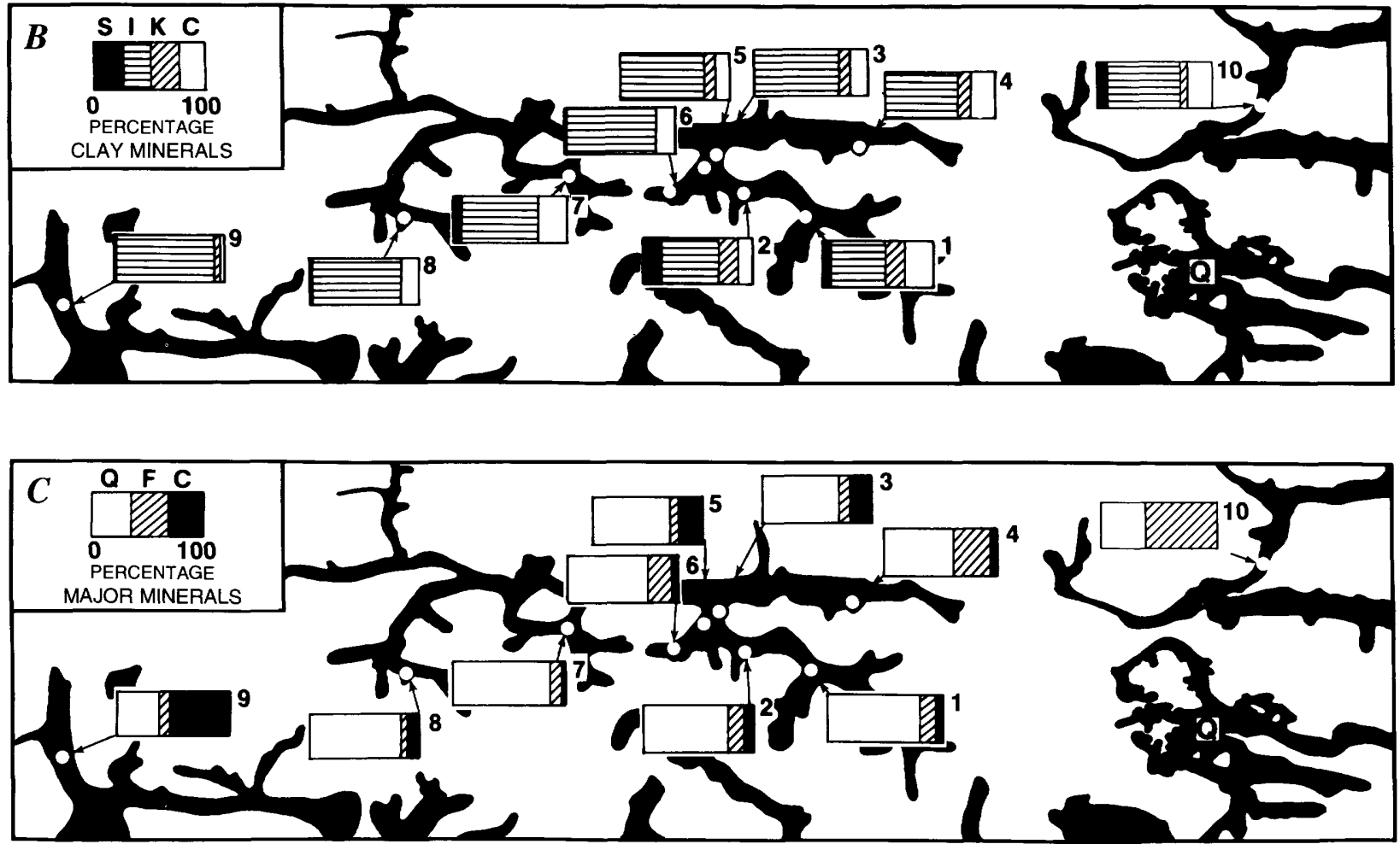

Figure 34. Valley of Yarlung Zangbo and vicinity, south-central part of Qinghai-Xizang (Tibet) Plateau, China, from Lhasa to Tingri, showing sites of sediment samples 1 to 10 (white circles). (See fig. 3 for geographic details.) A. Generalized geologic map from Academia Sinica (1980). B, Weighted peak-area percentages of clay minerals in $<0.005-\mathrm{mm}$ fraction of sand and loesslike silt samples. S, smectite; I, illite; K, kaolinite; C, chlorite. Quaternary sediments shown in black. $C$, Weight-percentage estimates of major minerals in sand and loesslike silt samples. Q, quartz; F, feldspar (orthoclase and plagioclase); C, carbonate minerals (calcite and lesser dolomite). Quaternary sediments shown in black. 


\section{POLLEN}

Palynological research on loess of China began in the 1950's (Zhou and others, 1960) in the north-central part of the country and is now actively being pursued (Liu and others, 1985 p. 84-92). Pollen studies in the QinghaiXizang (Tibet) Plateau are not numerous, however. Huang and Ji (1981) and Wang and Fan (1987) report pollen in Holocene sediments near lakes in south Xizang Autonomous Region. Holocene peats have also been examined (Academia Sinica, 1980, p. 43-44; Wang and Fan, 1987, p. 50-52).

Huang Cixuan identified 25 types of pollen in seven sediment samples from the site above the highway on the south side of Xigaze in 1980. Her methods follow and her count and identifications are shown on figure 36.

\section{METHODOLOGY}

Samples of 100 to 200 grams were boiled for 1 to 3 minutes in a 5-percent solution of sodium hydroxide. After washing to neutral with distilled water, the samples were treated with dilute hydrochloric acid to dissolve the calcium carbonate. After again washing in distilled water, the samples were centrifuged in three different heavy liquids: Densities 2.3, 2.1, and 2.0. The remaining heavy material was diluted with three to five times its volume of acetic acid, then washed with distilled water. Next, the material was treated with a mixture of one part sulfuric acid and nine parts acetic acid and then washed with distilled water to neutral.

\section{RESULTS}

Analyses revealed few pollen, except in samples 12 and 16 (figs. 27, 36). Woody species make up less than 10 percent of the total pollen, and herbaceous species make up more than 90 percent; the latter are rich in Ranunculaceae and Artemisia (fig. 36).

These pollen, particularly Ephedra, Artemisia, Chenopodiaceae and Palygonaceae, suggest a dry-cold steppelike condition. However, several pollen types including
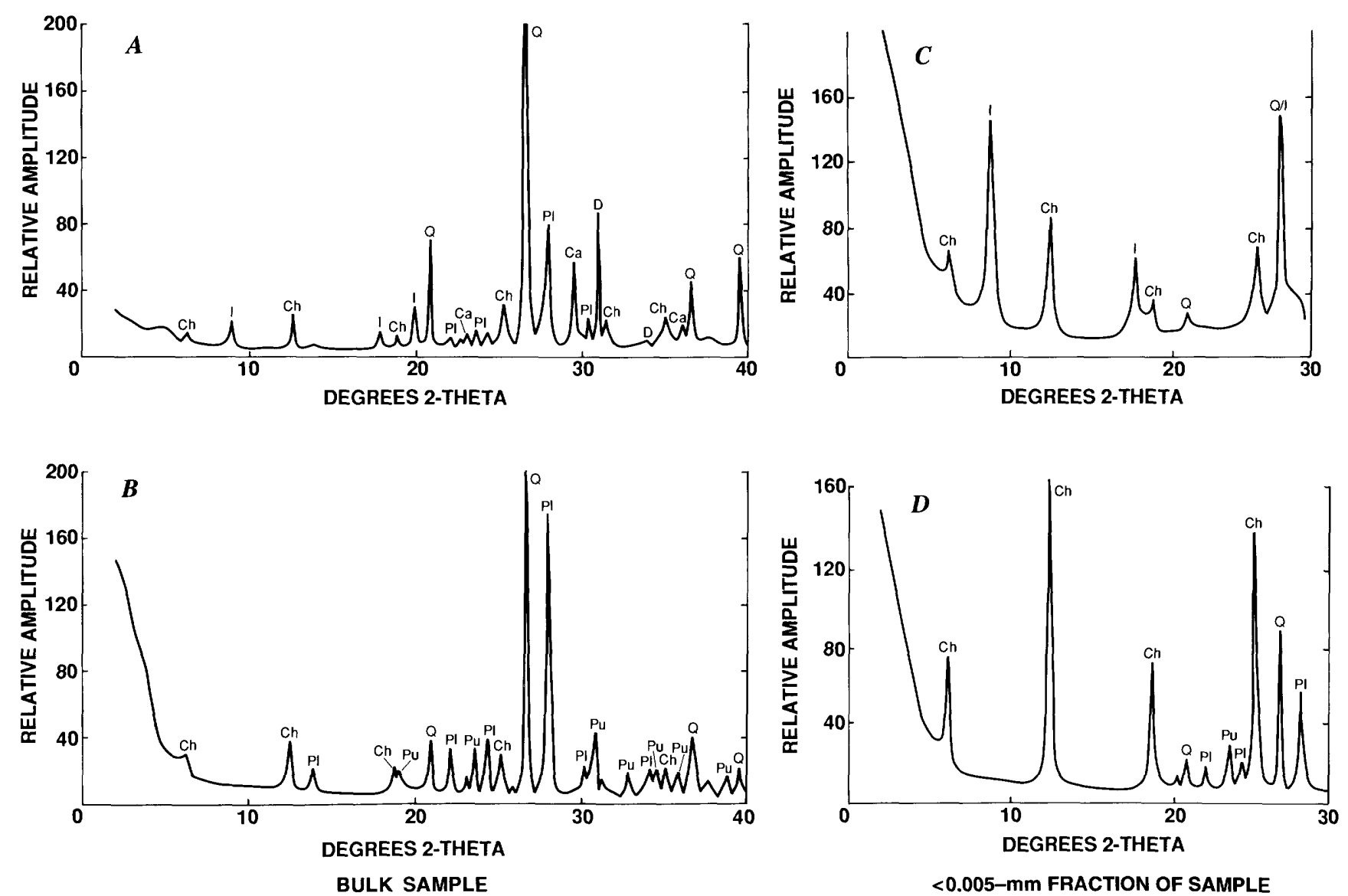

Figure 35. X-ray diffractograms of bulk and $<0.005-\mathrm{mm}$ fractions of loess sample $3(A, C)$ and sample of underlying bedrock of volcaniclastic sandstone and lithic tuff $(B, D)$ from rock knob $15 \mathrm{~m}$ high at junction of Nyang $\mathrm{Qu}$ and
Yarlung Zangbo, Xizang Autonomous Region, China. Ca, calcite; Ch, chlorite; D, dolomite; I, illite; Pl, plagioclase; $\mathrm{Pu}$, pumpellyite; $\mathrm{Q}$, quartz. (See figs. 22, 25 for sampling sites.) 
Ranunculaceae, Cyperaceae, and Gentianaceae, indicate meadows and local moist substrate such as small ponds and wet ground. Myriophyllum is aquatic.

\section{GASTROPODS}

Fossil snails are common in Chinese loess and have been described over many years (Chen and others, 1985). However, most if not all of the work has been restricted to the study of land gastropods. Although pulmanate gastropods live today in southern Xizang (Chen and others, 1985), we did not see any modern or fossil species in the loesslike silt. Péwé, $\mathrm{Liu}, \mathrm{Li}$, and associates collected many specimens of freshwater gastropods from two different zones in a 6-m-high exposure of loesslike silt on the south side of Xigaze (fig. 27, 37) in 1980. In both the upper and lower zones, the specimens were found in more or less horizontal layers a centimeter or two thick in relatively poorly stratified to almost unstratified silt containing some quartz and rock particles as much as $2 \mathrm{~mm}$ in diameter. The lower layer could be traced laterally for only about 10 $\mathrm{m}$ and the upper layer for 3 or $4 \mathrm{~m}$.

The lower of the two horizons has the highest concentrations of gastropods and is near the level of the road. The most common type and the largest species is Radix auricularia (L.) (fig. 38). The collection contains both juvenile and adult specimens that measure as large as 25 to
$30 \mathrm{~mm}$ high and 20 to $30 \mathrm{~mm}$ wide. This is a white spiral gastropod; the last spiral is so large that it almost appears to form the entire shell. The larger specimens appear to be standard for this species (Zhadin, 1952, p. 118). The second most common species is a brownish or tan-colored, vertically coiled Fossari truncatula (Muller). It is much smaller than $R$. auricularia - only 5 to $7 \mathrm{~mm}$ high and only 3 or $4 \mathrm{~mm}$ wide. The least common gastropod is the small white Planorbidae, Gyraulus gredleri (Gredler). It is coiled in a rather flat horizontal plane, and these specimens are only about 1 to $3 \mathrm{~mm}$ in diameter.

The upper zone of gastropods is 3 to $5 \mathrm{~m}$ higher in the section (fig. 27), and contains fewer specimens than the lower zone. Only two different species were found. Most common by far was Fossari truncatula (Muller), and there were a few Gyraulus gredleri (Gredler).

Living specimens of these species are chiefly Eurasian in distribution, in areas of cold fresh water, and they have been reported from Quaternary deposits in the former Soviet Union, Alaska, and northwest Canada (Péwé and Journaux, 1983; Clarke and Harington, 1978). F. truncatula also lives in Newfoundland and British Columbia. Unfortunately, the terminology for these species is not always the same in different countries, and there has been a constant evolution of terminology over the years. This problem has been carefully pointed out by Zhadin (1952) and by Clarke (1973, p. 483). For example, Radix auricularia (L.) is also known as Lymnaea auricularia (L.).

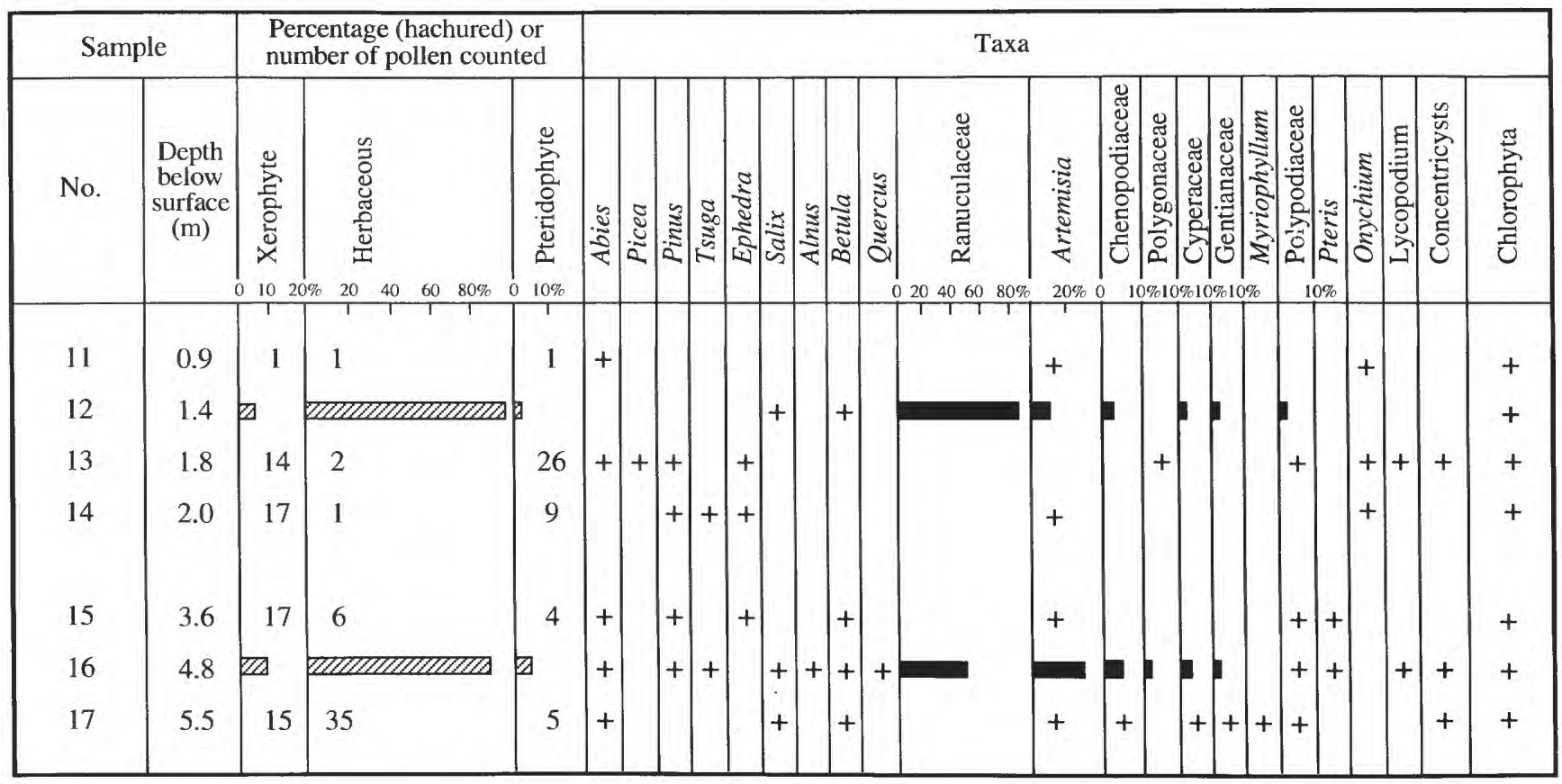

Figure 36. Pollen composition of sediment samples from stratigraphic section (fig. 27) on scarp of terrace on west side of Nyang Qu, south of Xigaze, Xizang Autonomous Region, China. Hachured bar, percentage sum of individual taxa clas- sified as Xerophytic (dry), Herbaceous (moist), or Pteridophytic (fern). Solid bar, percentage of individual taxa in assemblage. + , species present but not counted. Analyses by Huang Cixuan. 
Radix auricularia (L.) lives in the marginal zones of large and small bodies of water such as rivers and brooks, and has been reported in Siberia (Zhadin, 1952, p. 118). Lozek $(1964$, p. 177) reports that the species is Paleoarctic and lives in plant-rich standing water. Péwé has collected it from cold-water ponds in central Alaska near Fairbanks and in western Alaska near Galena. Coworkers have found it in Quaternary sediments elsewhere in Alaska. The retransported loess of late Wisconsin age in central Alaska is rich in organic remains, including some fresh-water gastropods. Mertie (1937, p. 192-193), Taber (1943, p. 1491), and Péwé (1975a, p. 88-89) record Stagnicola and Gyraulus gredleri in the retransported loess of central Alaska. Zhadin $(1952$, p. 125) mentions that Fossari truncatula
(Muller) is widespread in the former U.S.S.R., is Paleoarctic, and has been found in Quaternary deposits in both east and west Siberia. He states that this species lives in silty biotopes and in cold or hot springs, as well as in swamps, pools, and rice fields; it occurs at elevations as high as 2,000 $\mathrm{m}$ above sea level. The gastropods at the Xigaze site, which is at $3,836 \mathrm{~m}$, indicate that the ecological conditions under which they lived were mainly shallow ponds, probably on very gentle slopes, low terraces, and the flood plain of the Nyang Qu in late Quaternary time. As the fine-grained silt was carried by sheet wash and small rivulets across the gentle slopes from the hillsides to the terraces and flood plain, the ponds became filled, and adjacent land surfaces were aggraded as the sediment accumulated.

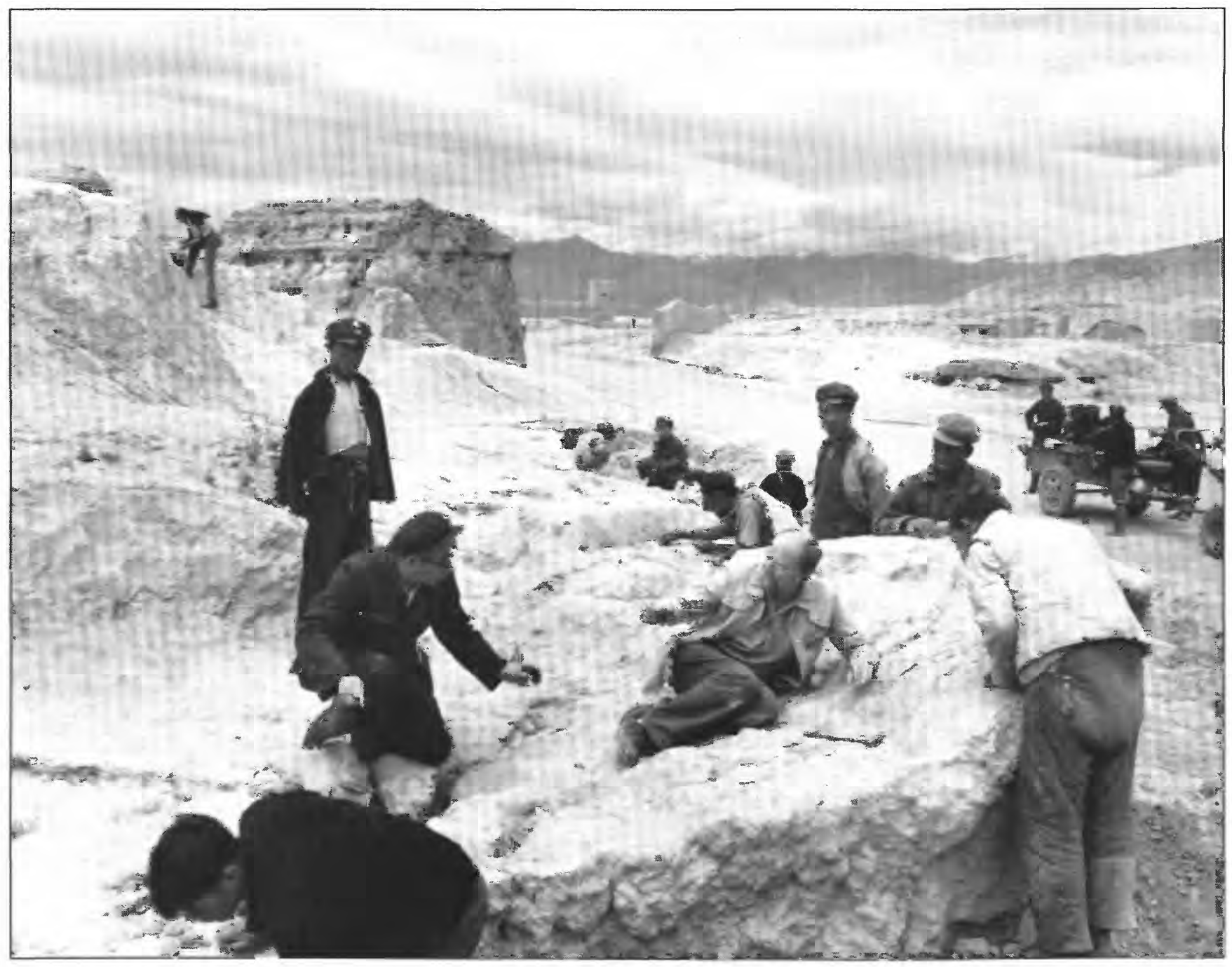

Figure 37. Collecting fossils in loesslike silt at river-terrace exposure south of Xigaze, Xizang Autonomous Region, China. Fresh-water mollusks from lower shell bed, right-center foreground; rodent and bird fossils from sedi- ments beside collector at far upper left. Loess-brick wall in center background and a brick yard at upper far right. (Also see fig. 27, 28.) Photograph 4577 by Troy L. Péwé, June 9, 1980. 


\section{VERTEBRATES}

Reports of Quaternary vertebrate fossils from Xizang Autonomous Region are not common. The few specimens collected in the 1970's during expeditions to the Qinghai-Xizang (Tibet) Plateau expeditions are reported by Huang (1980) and Huang and Ji (1981). Except for the Ovis sp. and Cervus reported from a cave in bedrock near Maizhokunggar (fig. 3), the remaining four localities reported by Huang (1980) are probably in loesslike silt.

An Equus sp. tooth was found in yellowish soil at Tingri (fig. 3), and two lower right jaw bones of Alticola $\mathrm{sp}$. were in or near vertically jointed loesslike mud at Xiegal. Parts of Equus sp. and Bos sp. were recovered at Yangbajian from a 19-m-thick sediment layer believed by Huang (oral commun, 1986) to be retransported loess. A late Pleistocene metatarsal bone of Cervus sp. was recovered from a brick and tile plant at Nyingchi. Although described as from fluvial and lake deposits, the sediments are probably retransported loess because, as elsewhere in southern Xizang, it is used to make brick and tiles.

A unique collection of vertebrate fossils was recovered by Péwé, $\mathrm{Liu}, \mathrm{Li}$, and associates from loesslike silt in an exposure near the top of a terrace along the Nyang Qu at the south side of Xigaze (figs. 25, 27, 28, 37). In silt,

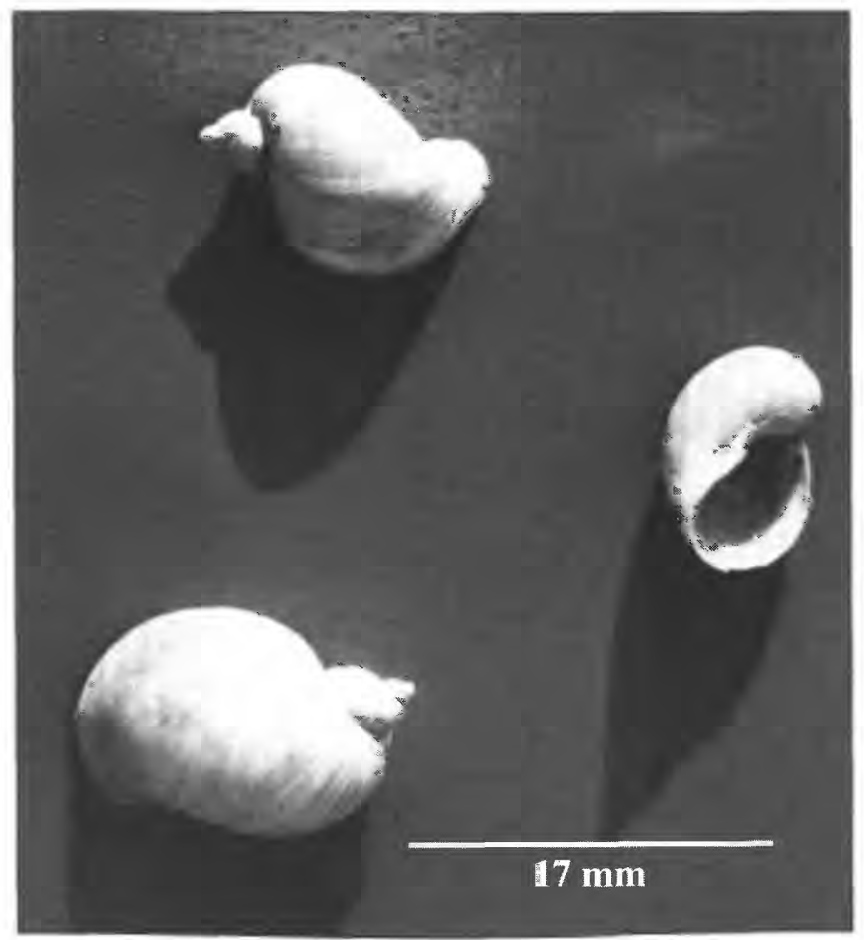

Figure 38. Fresh-water gastropods Radix auricularia (L.) from loesslike silt from stratigraphic section (fig. 28) on scarp of terrace, west side of Nyang Qu, south of Xigaze, Xizang Autonomous Region, China. Photograph PK 24,436 by Troy L. Péwé, Sept. 3, 1981. about $3 \mathrm{~m}$ below the surface, Bruno Messerli noted small, delicate vertebrate bones of four different birds and two different rodents, identified below, and the remnants of a bird nest.

Asio flammeus, a short-eared owl. At least two very young individuals probably less than half grown and obviously still nestlings at the time of death.

cf. Alauda arvensis, a skylark. At least three individuals. These specimens agree rather well with Alauda and do not seem to be similar to Eremophila, Galerita, or Lullula. The specimens are larger than available specimens of Alauda gulgula and therefore are most similar to A. arvensis.

Passer sp. (either montanus or rutilans), a sparrow. At least two individuals. Definitely too small for $P$. domesticus.

Passeriformes gen. et sp. indet., a song bird. One ulna and possibly two coracoids and two tarsometatarsi are from a passerine intermediate in size between Alau$d a$ and Passer.

Microtus (Pitimys) blythi, a Blyth's vole. At least 11 individuals.

Cricetulus kamensis, a Tibetan hamster. One individual.

The accumulation of vertebrate bones appears to be from a nest of the short-eared owl, and both nestlings and prey are represented. The species are all the same as those found in the southern plateau today. The owl and the lark are certain indicators of open country or grassland, and the owl may also indicate the presence of marshes. The area was probably one of a slowly aggrading flood-plain surface with small ponds and marshes. The bird and rodent bones in the old nest were covered by silt washed down from the slopes. Another interpretation is that the bones and the nest are much younger than the enclosing sediments and were deposited in a hole in the face of the silt cliff. Although small birds do live in holes in loess, the typical short-eared owl does not.

\section{ORIGIN OF LOESSLIKE SILT}

The origin of loess has been a controversial subject worldwide for about 100 years, and most of the discussions have centered on the loess in north-central China, central United States, and, later, Alaska and eastern Siberia. Less is known about the probable origin of the widespread loesslike silt in the valley bottoms and on flanks of the lower hills in the unglaciated southern part of the Qinghai-Xizang (Tibet) Plateau. Lacustrine, fluvial, weathering, and eolian processes have been invoked to explain the loesslike silt. The weathering or residual hypothesis has little support. The lacustrine hypothesis, either separately or with fluvial processes, has been held since the late 1970's and 1980's (Academia Sinica, 1980). The 
eolian hypothesis has been strongly suggested since 1980 (Péwé, 1980 a, b, 1981; and Péwé and others, 1981, 1985, 1987). Whatever the origin, it is evident that most of the silt has been retransported downslope by sheet wash, rill wash, creep, solifluction, and (or) by small ephemeral streams or rivulets.

\section{WEATHERING HYPOTHESIS}

In the early part of this century, L.S. Berg proposed and expounded in many publications of the former U.S.S.R. that loess forms in place as the underlying rock breaks down (summarized in Berg, 1964 [1960]). His hypothesis exerted a profound influence over many Soviet scientists, but now it seems to have little support in the western part of the former Soviet Union. In the 1950's, Soviet scientists carried the concept of the origin of loess by residual weathering to China. For example, Pavlinov (1959) stated that loess formed from destruction of local underlying bedrock. Many scientists in eastern Siberia continued to hold the view that the loesslike silt is a product of rock material broken down by seasonal freezing and thawing. The eolian origin for the loess in eastern Siberia was demonstrated by Tomirdiaro (1972) and Péwé and Journaux (1983).

It has been suggested that the loesslike silt in the southern part of the Qinghai-Xizang (Tibet) Plateau formed in place by disintegration of local country rock. If the loesslike silts were formed in place by disintegration of the local country rock, three conditions would be expected.

(1) The mineralogy of the silt and the underlying rock would be similar, allowing for differential resistance to weathering. However, the loesslike silt in the area overlies many substrates, including alluvium, poorly consolidated sands, glacial outwash, limestone, and various other types of bedrock. In the vicinity of Xigaze, loesslike silt overlies a 15-m-high bedrock knob near the junction of the Nyang Qu and the Yarlung Zangbo. Mineralogical analyses show that the silt (sample 3; tables $1,4,6$ ) could not have been derived from weathering, either chemical or mechanical, of the underlying rock, which is a volcaniclastic sandstone or lithic tuff that contains pumpellyite that is not present in the silt. Furthermore, the silt contains illite, which is not in the underlying rock.

On the south side of the Yarlung Zangbo, about 50 $\mathrm{km}$ downstream from Xigaze, a thick deposit of loesslike silt (sample 4, table 1) blankets the upper flanks of the valley almost to the top of a small knob of limestone (figs. 23, 24). Although the loesslike silt includes grains of limestone, most of it is composed of multicycle quartz grains and abundant feldspar grains. The silt could not have resulted from weathering of the underlying bedrock.

(2) If silt accumulated on top of a hill or a flat-lying area through the disintegration of underlying bedrock, the material at the surface should be finer and more weathered than that closer to bedrock. However, examination of the section of loesslike silt on the knob of rock near the Nyang $\mathrm{Qu}$ at Xigaze did not demonstrate this relation at all.

(3) The sediments produced by bedrock disintegration would undoubtedly contain some large bedrock particles, especially of the more resistant materials, and the contact with the bedrock would be gradational. No such particles were noted in the field, especially above the bedrock knob near Xigaze but also above other bedrock. The loesslike silt overlies the bedrock with a sharp contact, and coarse particles in the lower part of the section are scarce. The contact marks a striking change in textural and mineralogical composition.

In summary, a number of characteristics that would be expected in the loesslike silt if it were formed in place by disintegration of bedrock are not observed. The lack of all these conditions argues convincingly against the weathering hypothesis.

\section{LACUSTRINE HYPOTHESIS}

Only two publications suggest that thick deposits of loesslike sediments, especially in the bottoms of the valleys of Nyang Qu and elsewhere, may have been deposited in a now-drained Pleistocene lake at Xigaze (fig. 3) (Academia Sinica, 1980, p. 11; Zheng and Jiao, 1991). This idea was offered to explain the prominent silt terraces on the sides of the valley and the presence of fresh-water gastropods and ostracodes (figs. 25, 26, 27). The lacustrine hypothesis is improbable for several reasons:

(1) Barriers capable of damming water up the Yarlung Zangbo and Nyang Qu have not been proven to exist. Years ago, Ward (1926) examined the gorges for barriers of the Yarlung Zangbo without success. However, it is possible that the Yarlung Zangbo and its tributaries could have been flooded in the past.

(2) Evidence of shorelines, wave-cut benches, and deltas would be preserved in a lacustrine environment, but no such features are associated with the silt.

(3) Lacustrine deposits have a limited vertical extent, but the loesslike silt is found at various elevations, even on moraines in the Yangbajain valley.

(4) Lacustrine silt would be stratified and might even contain varves. This silt is poorly stratified, but some well-stratified sand-and-gravel beds occur locally. In no instance does the stratification resemble lacustrine bedding.

(5) An appreciable amount of clay could be expected in deposits of any large lake. Most of the sediment samples in the valley-bottom deposits are of silt or sand; however, locally the clay component is 30 to more than 40 percent.

(6) Lacustrine deposits would bear little lithologic relation to the underlying rock. This characteristic, howev- 
er, is typical of any transported sediment, including the loesslike silt.

(7) Some forms of life would have existed in these lakes. So far as; we are aware, no lacustrine fossils such as fish have been found in the silt, although gastropods, ostracodes and pollen occur. Most of the pollen suggests an origin in meadows and small ponds, not in large deep lakes. The ostracodes indicate the same environment. The gastropods indicate mainly shallow ponds and marshes, probably on very gentle slopes, low terraces, and flood plains; they are not characteristic of large lakes.

(8) Land fossils would be absent or scarce in lacustrine deposits. The few mammal remains found in the silt indicate a land environment. In the thick loesslike silt deposits at Xigaze, the bones of four different birds and two different rodents that were found indicate an environment of small ponds and marshes, not a large lake.

(9) Mud cracks and ripple marks would be expected in lacustrine silt, but none have been observed in the loesslike silt.

All but one of these features that are characteristic of lacustrine deposits are contrary to the observed nature of the loesslike silt. The one feature (sample 6) that is consistent is typical of deposits transported by any mechanism. The observed characteristics of the silt in the southern part of the Qinghai-Xizang (Tibet) Plateau cannot be explained by the lacustrine hypothesis.

\section{EOLIAN HYPOTHESIS}

Scientists with the Qinghai-Xizang (Tibet) Plateau expeditions in the 1970's referred to some of the silt on and in the fans flanking the lower parts of the mountains and in valley bottoms in the southern part of the area as loesslike deposits (Zhao and others, 1976; $\mathrm{Li}$ and others, 1983). The first published suggestions that the silt was retransported loess probably were by Péwé (1980 a, b, 1981) and Péwé and cthers $(1981,1985,1987)$. This study of the silt in the southern part of the Qinghai-Xizang (Tibet) Plateau, and our comparison with similar deposits elsewhere in China and other parts of the world, supports the identification of the deposits as loess and retransported loess.

Features and characteristics of eolian-deposited silt fall into three groups: field relations, mechanical composition, and petrographic character (Smith and Fraser, 1935).

\section{FIELD RELATIONS}

\section{TOPOGRAPHIC DISTRIBUTION}

As clearly stated by Barbour (1930, p. 468), in reference to the loess of central China, the mantle of loess "conforms closely to the general contouring of the buried preloess topography, filling up the gullies, covering the minor elevations, lying deepest in the depressions and thinning-out up the flanking slopes of the higher ridges." The loesslike silt in the Qinghai-Xizang (Tibet) Plateau occurs as a surficial mantle and fits Barbour's description. It is thin on top of low hills, is thicker on the flanking fans, and reaches maximum thickness in the broad valley bottoms. A thin veneer of the silt remains on the rather flat passes or highlands where it has not been removed by down-slope processes.

\section{INDEPENDENT LITHOLOGIC CHARACTER}

Wind-deposited material usually differs mineralogically and texturally from the underlying material. In the southern part of the plateau, the loesslike silt covers sand and gravel, glacial till, and various types of bedrock. The fine texture of the silt contrasts strongly with the texture of the underlying material. Petrographic study of samples from the silt and bedrock at the knob at Xigaze, and at the limestone hill $50 \mathrm{~km}$ downstream from Xigaze, indicates mineralogical differences between the silt and the underlying bedrock.

\section{ABSENCE OF DISTINCT STRATIFICATION}

One characteristic of loess is the absence of distinct stratification in silt on top of hills. Within the study area, the loesslike silt on top of hills also lacks stratification. However, transportation of the silt from the slopes to the alluvial fans and to the valley bottoms produces poor to well-developed stratification, especially if interbedded with sand or gravel layers.

\section{COLOR AND TEXTURE}

Wind-deposited silt is generally light colored and stained by moving ground water or carbonaceous inclusions; the texture is generally uniform. In loess away from a river or not on slopes or valley bottoms, clay makes up no more than 10 to 15 percent of the sediment. The loesslike silt in the study area is comparable to loess elsewhere in the world, except that much of it is interbedded with sand and gravel.

\section{ASSOCIATION WITH OTHER EVIDENCE OF WIND ACTION}

Smith and Fraser $(1935$, p. 19) state that sand dunes and ventifacts may be expected near the source of material. The plateau is conventionally referred to as a wind-swept area and a land of blowing sand and dust. Inhabitants have 
long been aware of these conditions, and early western explorers remarked about the "raving wind," "wind roaring over the sandbanks," "perpetual harassing blasts," and "ruthless winds" (Ward, 1926). Two French Vincentian missionaries to Lhasa in 1896 bitterly complained of the terrible north wind that lasted 15 days and menaced them with distraction (Huc and Gabet, 1928, v. 2, p. 147-148). A professor of Oriental language from London, entering Tibet in disguise in 1923, remarked of the effect of the wind on the Yarlung Zangbo "**** so strong was the wind in the opposite direction [of the flow of the river] that its blasts on the river made it seem as if the water was flowing backward and uphill; in fact, so strong was the illusion that [the natives] thought it to be real and bowed down in worship of a supposed miracle." (McGovern, 1924, p. 285-286). Early western explorers also commented on the presence of immense sand dunes, especially in the Zangbo corridor (Rawling, 1905). Various types of dunes, especially climbing dunes (cover photograph, fig. 16), occur along the broad, gravel-floored valleys of major streams (Zhao and others, 1976, p. 6; Wang and Fan, 1987; Reiter and Reiter, 1981). David-Neel (1927, p. 299-300) commented about invading sand in 1923:

Quite near Lhasa, on the left bank of the Brahmaputra [Yarlung Zangbo], one finds a miniature Sahara whose extensive white dunes are invading the whole country***.

\begin{abstract}
*** In spite of a ridge which stood in their way, the sands have taken a firm footing in the Kyi Valley, and though still shallow on that side, their fine dust is beginning to accumulate along the hedges which border Norbu ling, the pleasure garden of the Dalai Lama. It may possibly be that in a few generations Lhasa will be reached. Who knows whether, in a still more distant future, some savant, excavating the entirely submerged city, may not discover the Potala and the Jo Khang, just as we now lay bare the palaces and temples which the sands of the great Gobi have overwhelmed***.
\end{abstract}

On our way $* * *$ there were a few more villages whose fields are gradually disappearing beneath the mounting sands.

These dunes are evidence of eolian action still active on the almost vegetation-free flood plains (figs. 13, 15).

Bare sand-and-gravel bars of the braided streams (cover photograph and figs. 12-14) also provide an excellent source area for enormous clouds of blowing dust that are common in late winter, spring, and early summer. A rare photograph of clouds of dust beginning to form on the bare flood plain of the Lhasa He near Lhasa in 1954 is illustrated by Sîs and Vanišs (no date, pl. 50). The duststorms range from a "maze of dancing dust devils" (Ward, 1926, p. 43) to "huge black clouds approaching rapidly" (Harrer, 1953, p. 163). Harrer further states (1953, p. 163) that in Lhasa, "*** the Potala Palace disappears and at once everyone rushes for home. Street life stops." and (p. 316) that the departure of the Dalai Lama from Lhasa to India on March 19,1959 , occurred during a notorious sandstorm and duststorm that immobilized Lhasa in the early evening.
Commenting further in this vein, Alexandra DavidNeel (1927) reported that she became the first foreign woman in Lhasa in 1923 when an immense dust storm permitted her to enter the Forbidden City undetected as she states (p. 256-257):

All of a sudden a furious storm arose, lifting clouds of dust high into the sky. I have seen the simoon in the Sahara, but was it worse than this? No doubt it was. Yet, that terrible dry lashing rain of dust gave me the impression of being once more in the great desert.

Indistinct forms passed us, men bent in two, hiding their faces in the laps of their dresses, or whatever piece of cloth they might happen to have with them.

Who could see us coming? Who could know us? An immense yellow curtain of whirling sand was spread before the Potala, blinding its guests, hiding from them Lhasa, the roads leading to it, and those who walked upon them. I interpreted it as a symbol promising me complete security, and the future justified my interpretation. For two months, I was to wander freely in the lamaist Rome, with none to suspect that, for the first time in history, a foreign woman was beholding the Forbidden City.

"The gods threw a veil over the eyes of his adversaries and they did not recognise him." So went an old Thibet's tale which I had heard long ago.

Present day reports support these early views (Han, 1979, p. 166):

The wind. A blinding, laceration blizzard of sand and stone, and the whole world destroyed by this maelstrom of small pebbles whirling in the choking air. Lips, hands and face are flayed. The turquoise sky, the white houses, even the Potala, are no longer, all swallowed in a yellow opaqueness which is the wind $* * *$. For three days the wind blew, and no planes came $* * *$. Then, relief. With the night the wind abates though an overhang of sand [dust] will remain in the air for another day or more. In the past, the lamas $* * *$ blew long silver trumpets to compel the wind away.

In the absence of silver trumpets, similar or larger clouds of dust in late Pleistocene times undoubtedly deposited silt onto the slopes of the hills and mountains (cover photograph). Many workers have demonstrated that no more wind is necessary to blow that dust than is present today, as winds of $20 \mathrm{~m} / \mathrm{s}$ are more than strong enough to bear quantities of dust in both periglacial areas and hot desert areas (Bryan, 1927, p. B39-B40; Péwé, 1951; Warn, 1953; Péwé and others, 1976, 1981b). If there were larger source areas than today in late Pleistocene time, such as wider unvegetated flood plains of braided streams, from more extensive glaciated areas (Shi and others, 1993, fig. 3; $\mathrm{Li}$ and $\mathrm{Li}, 1991$ ), wind-blown dust must have been abundant. In fact, Feng and Thompson (1989) and Zhang and others (1991) state that silt from the northern part of the Qinghai-Xizang (Tibet) Plateau may have 
blown eastward to the great loess plateau of central China north of Xian (fig. 1) during Pleistocene time.

\section{FOSSILS OF AIR-BREATHING ANIMALS}

Fossils of air-breathing animals should logically be expected in the silt if the material is eolian. Late Pleistocene vertebrate fossils recorded in the loesslike silt in the southern part of the Qinghai-Xizang (Tibet) Plateau (Huang, 1980) include remains of horse, bison, and other mammals. Bones of two types of rodents and four types of birds were found in the loesslike silt near Xigaze. The preservation of many of the specimens shows very little evidence of transportation.

Although land gastropods are well known from loess in central China, none are reported in the loesslike silt in the southern part of the Qinghai-Xizang (Tibet) Plateau. Nevertheless, Succinea representatives live in the area today. Russell (1944, p. 34) regarded land gastropods as being characteristically present in loess. However, land gastropods have not been found in some U.S.A. loess in the upper Mississippi River valley or in most of the loess in Alaska (Péwé, 1955, p. 720-721).

\section{MECHANICAL COMPOSITION}

In loess, the grain-size and degree of sorting is similar to that of windblown dust or volcanic ash that has been transported a considerable distance (Udden, 1898, p. 3160; Swineford and Frye, 1945, p. 252; Warn and Cox, 1951, p. 559; Péwé, 1955, fig. 11; Péwé and others, 1976). Some of the material on the Qinghai-Xizang (Tibet) Plateau is similar to silt known to be loess. Cumulativefrequency grain-size curves of mechanical analyses of windblown dust from Arizona, Kansas, and Germany are similar to those of loesslike silt from the top of a bedrock knob (sample 3) and from other localities in the plateau, where the silt is near the river (sample 4) or is slightly retransported (sample 6; fig. 39).

Samples 3, 4, and 6 from the southern part of the plateau were compared with samples from deposits of silt of known eolian origin from elsewhere in the world (fig. 40). The great similarity of grain size and degree of sorting between the samples constitutes a strong argument for the eolian hypothesis. Cumulative-frequency grain-size curves of that loesslike silt from near Xigaze are compared with curves of known loess samples collected from Beijing, New Zealand, Alaska and Illinois in the U.S.A., France, the former Czechoslovakia, Siberia, and Uzbekistan. The sample of loesslike silt that has been retransported (sample 6) is mixed with different sediment sizes and bears less resemblance to primary loess.

\section{PETROGRAPHIC CHARACTER}

Angular grains have long been considered typical of loess (Barbour, 1925a, fig. 1; Twenhofel, 1932; Charlesworth, 1957), and scanning-electron-microscope analysis supports that assumption (Cegla and others, 1971; Pye, 1987). Silt grains from the Qinghai-Xizang (Tibet) Plateau are clearly angular, especially light minerals such as quartz. Loess grains probably should also be largely unweathered, and clay minerals among them should be largely unweathered (Smith and Fraser, 1935; Charlesworth, 1957), although the degree of weathering would depend on the age and rate of deposition of the sediment and the effects of diagenetic processes. The loesslike silt from the plateau, like upper Pleistocene loess from other parts of the world, is relatively fresh but shows some weathering under the scanning electron microscope.

\section{SUMMARY}

The characteristics of loesslike silt in the QinghaiXizang (Tibet) Plateau and the similarity between it and primary loess support the eolian hypothesis. In the light of this evidence, we conclude that the unstratified loesslike silt on top of bedrock hills of the plateau is primary loess, and that the poorly to well-stratified loesslike silt on the lower slopes and in valley bottoms of the major river valleys is retransported loess.

\section{RETRANSPORTED LOESS}

Very little of the loesslike silt in the southern part of the Qinghai-Xizang (Tibet) Plateau is primary loess; most of it is called "retransported loess" in this report. The retransported loess has been transported a few meters to hundreds, if not thousands of meters downslope, primarily by processes involving water. It is poorly to fairly well stratified and is intercalated with sand-and-gravel layers. With increasing distance from the hills and mountains, the sand, gravel, and other detritus became finer, and the numbers of layers of coarse sediments also decrease.

Retransported secondary loess is not unique to this area; it is widespread in the world, especially in areas of hills and mountains. Andersson (1923, p. 129) reported such deposits from central China many years ago and used the term "redeposited" loess:

In many valleys within the loess areas there are deposits of loess interstratified with gravel and occurring under such conditions that they must evidently be regarded as representing later depositions derived from the genuine loess. They are valley deposits of very limited extent with rapid and irregular changes of the stratification. Thick beds of 
gravels suddenly appear, and the gravel component of these deposits is far more abundant than is the case in the genuine loess. Everything goes to show that in the formation of the secondary loess-gravel beds water action has been the dominant factor and the wind has played only a very subordinate role. I call these deposits Redeposited Loess in order to distinguish them from the genuine Primary Loess.

Such secondary loess deposits are known elsewhere in the world, and they have been described in various ways in different languages. Other terms include "alluvial loessial deposits" (Wang and Song, 1983), "loess-like slope deposits," "deluvial loess," "slope loess," a quite appropriate term "mountain loess" (Pecsi, 1965, 1967), and "colluvial silt" (Li and others, 1983). In Alaska, the term "retransported silt" has been used, and "muck" is used in the sub-Arctic and Arctic Alaska where the retransported material has a high organic content that has been frozen since the time it was deposited (Péwé, 1968, 1975a, b; Péwé and others, 1989). The frozen material has preserved an abundant number of mammal remains, including perennially frozen carcasses.

In some regions where thick loess is well studied, the primary loess deposits interfinger and are interleaved with redeposited loess deposits. This interfingering indicates changes in climate and (or) the activity of erosional processes.

To more fully understand the characteristics of retransported loess in other parts of arid western China, and to compare such deposits with loesslike silt in the Qinghai-Xizang (Tibet) Plateau, Péwé examined retransported loess deposits and land forms on the south side of the Tian Shan in the Xinjiang Uygur Autonomous Region (fig. 1) in 1986 (Péwé, 1987) and discussed in detail with $\mathrm{Mu}$ Guijin in 1984 to 1986 the retransported loess deposits and landforms in the middle Ili He valley on the north slope of the Tian Shan. Mu is familiar in detail with the valley fills of loess in the Ili He valley and at Turpan (Mu, written commun., 1987; Yuan and others, 1983; and Wang and others, 1991). These deposits were classified as alluvial loessial deposits by Wang and Song (1983). It was immediately apparent to Péwé that this material in northwestern China exhibits the same characteristics as the loesslike silt in the southern part of the Qinghai-Xizang (Tibet) Plateau.

Turpan (figs. 1, 2, 5) lies in the hottest and lowest (154 $\mathrm{m}$ below sea level) part of China and is on the historical Silk Road. With irrigation from the mountains by the

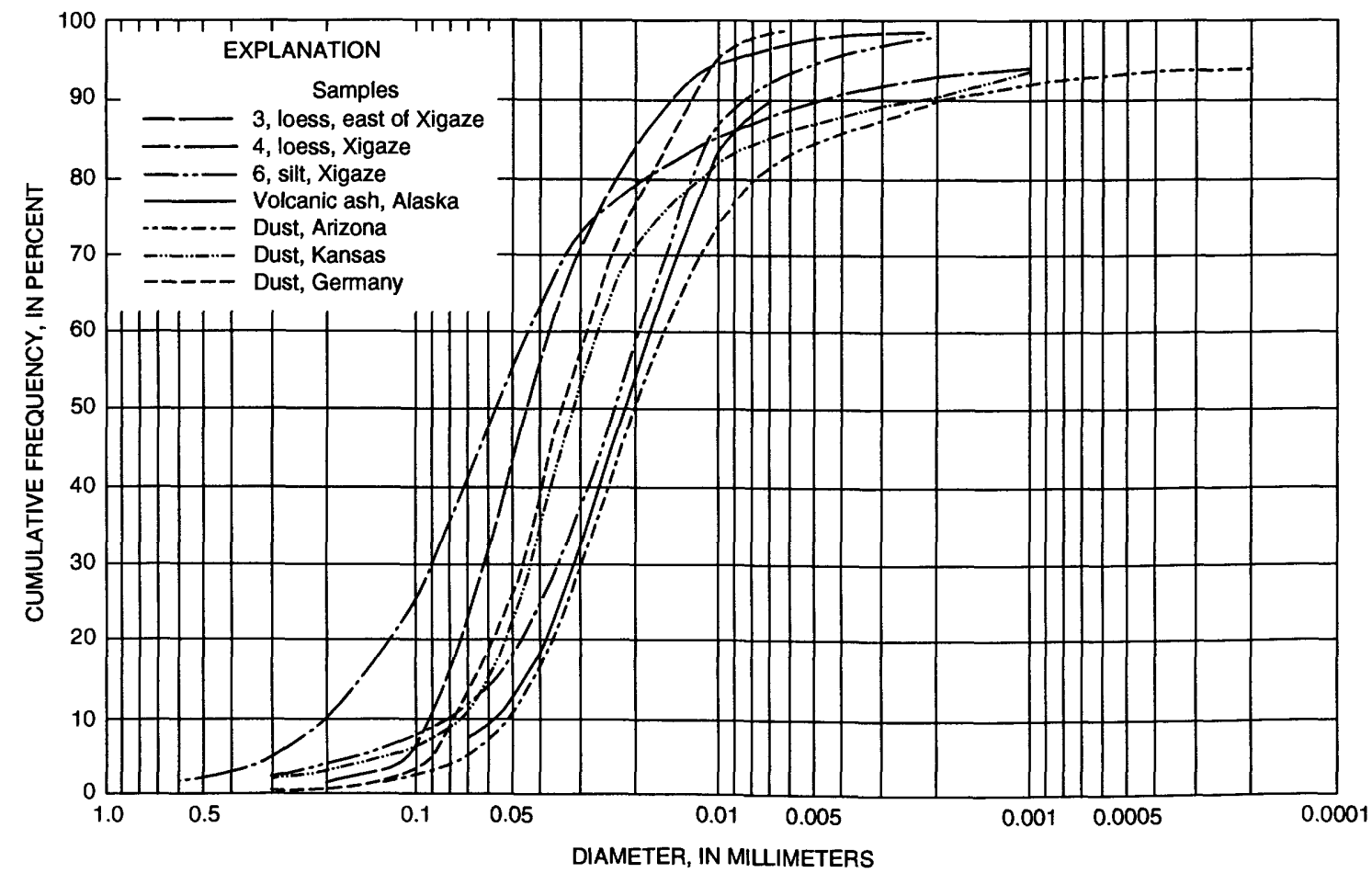

Figure 39. Cumulative-frequency grain-size curves for samples of loess (Nos. 3, 4) and retransported silt (No. 6) from near Xigaze, Xizang Autonomous Region, China, compared with those for volcanic ash (Ester Ash Bed) from near Fairbanks, Alaska (Péwé, 1955, fig. 11; pl. 2, fig. 1), and modern wind-deposited dust from roof of house at 538 E. Fairmont Dr., Tempe, Ariz. (Péwé and others, 1981, fig. 5), the third floor outside window sill, Lakeway Hotel, Meade, Kan. (Swineford and Frye, 1945, p. 252), and from Breslau, Selesia, Germany (now Wroclaw, Poland) (Zeuner, 1949, p. 27). Samples from Alaska, Arizona, and China collected by T.L. Péwé. Alaskan sample analyzed by U.S. Army Corps of Engineers, Rock lsland, Ill.; Arizona sample analyzed by André Journaux at Centre de Geomorphologie du Centre National de la Recherche Scientifique, Caen, France; Chinese samples analyzed by R.M. Slatt at Cities Service Company, Tulsa, Okla. 
method of underground canals (karez), the areas of retransported loess have become leading producers of excellent melons and grapes. Only $8 \mathrm{~km}$ west of Turpan, at the ruins of the ancient city of Jiaohe (figs. 41, 42), small streams are entrenched $30 \mathrm{~m}$ or more into the valley fill of retransported loess to produce vertical walls and mesas (figs. 43,44 ) that are strikingly similar to the terraces and mesas cut into the poorly bedded loesslike silt at Xigaze (figs. 26, 27) in the Qinghai-Xizang (Tibet) Plateau. Granulometric analysis of the retransported loess at Jiaohe (sample 18) yields a cumulative-frequency grain-size curve similar to those of loesslike silt from near Xigaze (table 1, figs. 39, 45). The curves are not like those of primary loess. Retransported loesslike silt at Kuqa (figs. 1, 2, 5; table 1, sample 19), $600 \mathrm{~km}$ west of Turpan, has interbedded gravel layers similar to those in fans in the Qinghai-Xizang (Tibet) Plateau. Cumulative-frequency grain-size curves show that the loesslike silt at Kuqa is coarser than that at Jiaohe and has a lower clay-size content (fig. 45).

Retransported loess along the middle Ili He valley on the north slope of the Tian Shan forms terraces similar to those at Xigaze (fig. 46). The upper slopes of the valley walls are blanketed with primary loess of late Pleistocene age. A cumulative-frequency grain-size curve of clay-rich primary loess $15 \mathrm{~km}$ north of Nilka (sample M7, fig. 45; Mu Guijin, written commun., 1992) on the Ili He is similar to one for primary loess in the Qinghai-Xizang (Tibet) Plateau (sample 3). Poorly bedded retransported loess of late Pleistocene and Holocene age overlies sand-and-gravel alluvium of middle Pleistocene age (fig. 46) in the valley bottoms. At least two flat-topped terraces have been cut into the retransported loess by the river.

\section{AGE AND CORRELATION OF SILT DEPOSITS}

Although loess has been accumulating throughout Quaternary time in the areas of classic thick loess of north-central China (Burbank and $\mathrm{Li}, 1985$; Heller and Liu, 1982, 1984; Heller and others, 1989; Liu and Yuan, 1982; Liu, 1987; Rutter and others, 1991), loesslike silt of the southern part of the Qinghai-Xizang (Tibet) Plateau

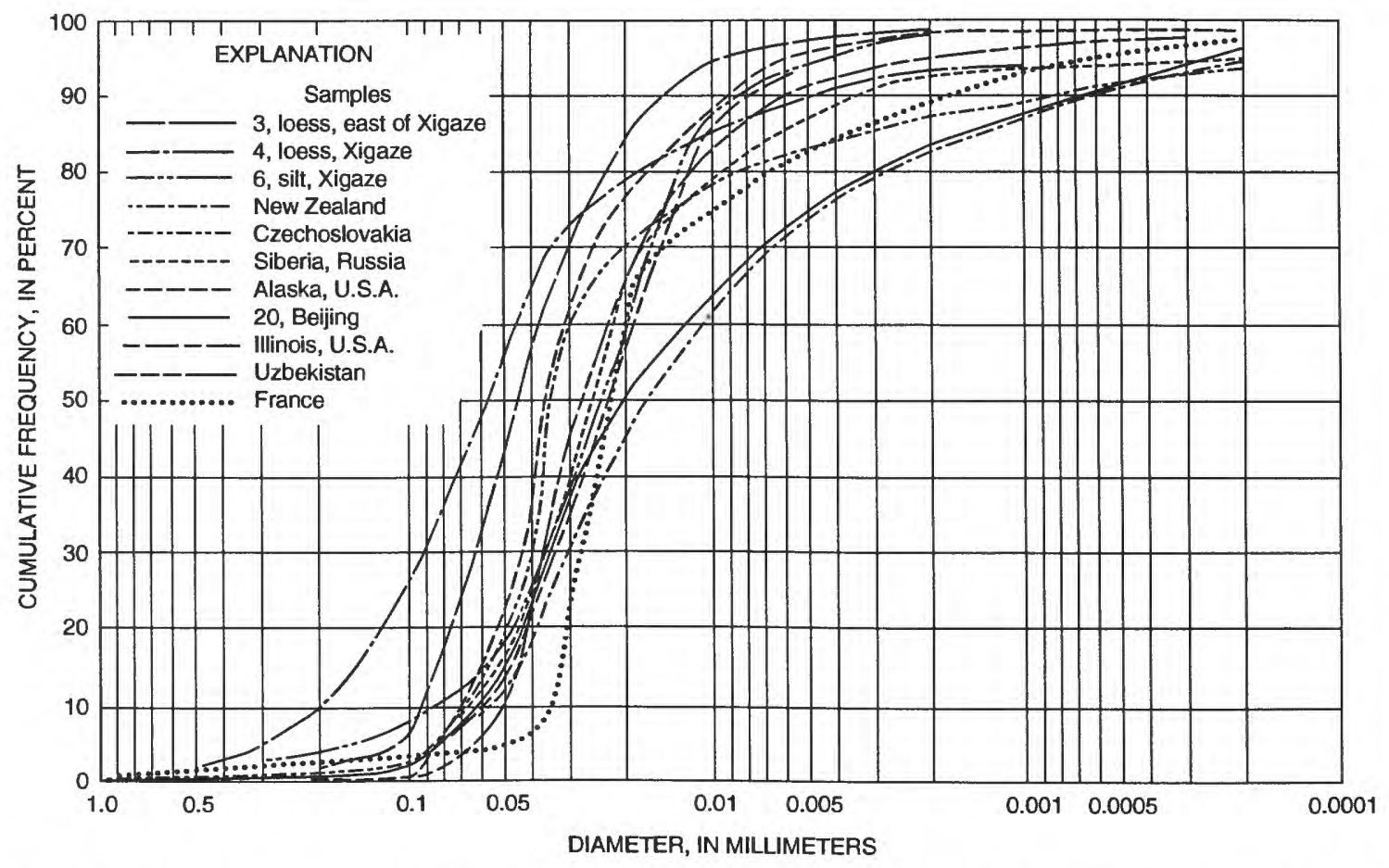

Figure 40. Cumulative-frequency grain-size curves for samples of loess (Nos. 3, 4) and retransported silt (No. 6) from near Xigaze, Xizang Autonomous Region, China, compared with those for loess from around the world: West side of Banks Peninsula, $40 \mathrm{~km}$ south of Christchurch, New Zealand; Brno, Czechoslovakia; $60 \mathrm{~km}$ northeast of Yakutsk, Yakutia (now Siberian Russia) (Péwé and Journaux, 1983, fig. 29, sample K); Fairbanks, Alaska (Péwé, 1955, fig. 11); Beijing, China (sample 20); Rock Island, Illinois; $50 \mathrm{~km}$ south of Samarkand, Uzbekistan; and near Caen, Normandy, France. Sample from France collected by André Journaux; sample 20 collected by R.J.E. Brown; all others collected by T.L. Péwé. Illinois and Alaska samples analyzed at U.S. Army Corps of Engineers, Rock Island, Ill.; samples 3, 4, and 6 analyzed by R.M. Slatt at Cities Service Company, Tulsa, Okla. Other samples analyzed at Centre de Geomorphologie du Centre National de la Research Scientifique, Caen, France, under direction of André Journaux. 
seems to represent only late Quaternary time. Vertebrate remains in the retransported loess are late Quaternary, although Huang (1980) states that paleontological studies of loess in the southern Qinghai-Xizang (Tibet) Plateau are only just beginning and that middle Quaternary vertebrates may be recovered during further investigations.

Attempts to date gastropod shells from the $15-\mathrm{m}$ high section of retransported loess at Xigaze (fig. 27) give interesting results. The shells were taken from the upper shell bed near the top of a section, which is thought to be of late Pleistocene age, where considerable subsequent downcutting has left high terraces on both sides of the Nyang Qu (figs. 25, 26, 27). The shells submitted by Anders Martinsson show a radiocarbon age of 2,010 $\pm 85 \mathrm{yr}$ B.P. (U. Olsson, written commun. to Liu Tungsheng, 1981). Olsson also stated that the "sample was a little too small." Gastropod shells collected by Péwé show a radiocarbon age of 3,645 \pm 110 yr B.P. (Robert Stuckenrath, written commun., 1981, laboratory sample SI-4651). Stuckenrath found the date puzzling and concluded from his testing that the snails must have been heavily charged with radon from their local microenvironment. Both laboratories, therefore, consider the ages questionable.

\section{SUMMARY}

Retransported loesslike silt occurs as fans and valley-bottom deposits in the southernmost part of the Qinghai-Xizang (Tibet) Plateau. The loesslike silt, reaching thicknesses of as much as $15 \mathrm{~m}$, is well sorted, poorly stratified, and interbedded locally near the hills and mountains with layers and lenses of sand and gravel. It overlies all substrates with a sharp contact and contains minerals not present in the underlying bedrock. The loesslike silt is massive, stands in sheer cliffs, and is strikingly eroded by narrow steep-walled gullies. It contains a few land vertebrate fossils and fossil gastropods that lived in shallow fresh-water ponds.

Hypotheses to explain the origin of the loesslike silt have included residual, lacustrine, and eolian processes. The hypothesis that loesslike silt is a residual product of

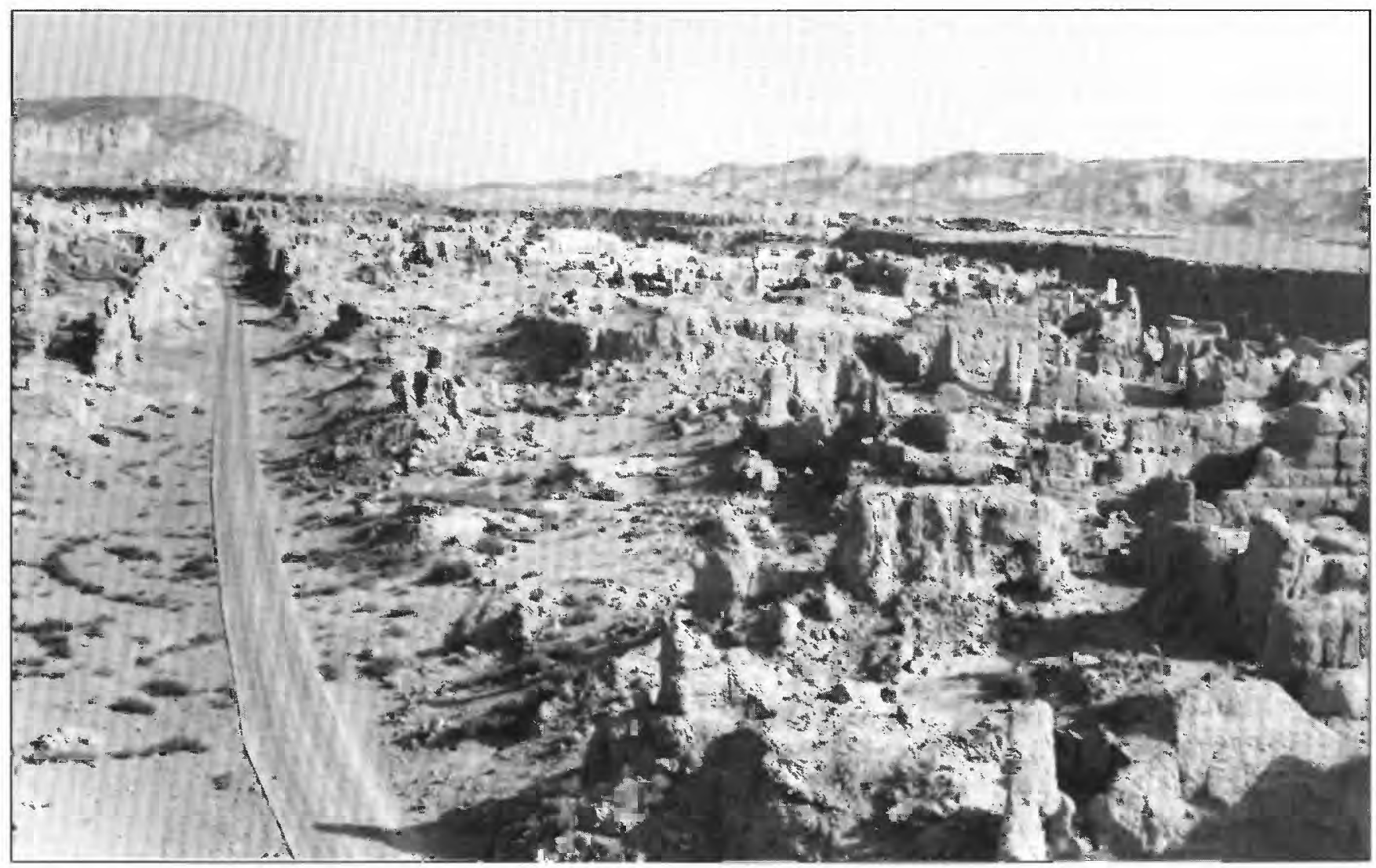

Figure 41. Ruins of ancient city of Jiaohe $8 \mathrm{~km}$ west of Turpan, Xinjiang Uygur Autonomous Region, China (figs. 1, 2). City in this arid region existed about 2,000 years ago; walls of loess bricks were built on mesa of retransported loess $30 \mathrm{~m}$ high and bounded on three sides by two steep-walled narrow valleys.
View southeast toward flat aggradational surfaces of retransported loess beyond valley that crosses near top of photograph. (Also see figs. 42,43 , and 44 and compare with fig. 26 that shows mesa-like remnants of retransported loess at Xigaze, China.) Photograph 4900 by Troy L. Péwé, Aug. 5, 1986. 
breakdown in place of the underlying rocks, mainly by frost action, has little support. Evidence against this hypothesis includes (1) minerals in the silt are not everywhere similar to those in the underlying bedrock, (2) no large particles of more resistant minerals are present, and (3) the silt does not become progressively coarser toward bedrock.

The lacustrine hypothesis is strongly supported by scientists in some areas because of the prominent silt terraces along the sides of valleys and because of the presence of fresh-water gastropods and ostracodes. But several circumstances indicate this origin is unlikely. No shorelines, wave-cut beaches, or deltas are present; nor are ripple marks, mud cracks, and deep-water lake fossils found. Neither lacustrine stratification nor an appreciable amount of clay exists in the silt. No definite upper limit of the deposits, to be expected under a lacustrine hypothesis, is present.

Evidence for the eolian origin of the upland silt is abundant. (1) The silt blankets older topography. (2) It is lithologically independent of the underlying material. (3) Stratification is indistinct or absent on small hilltops where the silt has not been retransported. (4) The silt is abundant in areas having sand dunes and active duststorms. (5) It contains fossils of air-breathing animals. (6) Sorting and texture of the loesslike silt on hilltops or near hilltops are similar to those of loess and windblown dust from many different areas in the world. (7) Individual silt grains are angular and relatively fresh.

The only glaciation in the southern part of the Qinghai-Xizang (Tibet) Plateau has been in the high areas of the Himalayas, the Nyainqentanglha Shan, and associated mountains in the upper reaches of the Yarlung Zangbo. Valley glaciers in these mountains were more extensive during glacial maxima, and unvegetated floodplains, characteristic of the modern major streams, were more widespread then. We believe the upland silt on the plateau is loess that was deposited against the hills and mountains by winds blowing across the unvegetated floodplains and the desert rocky plains to the north during late Quaternary time. Most of the loesslike silt on the plateau is silt retransported loess that has been moved downslope and redeposited by rillwash, sheetwash, stream action, and solifluction.

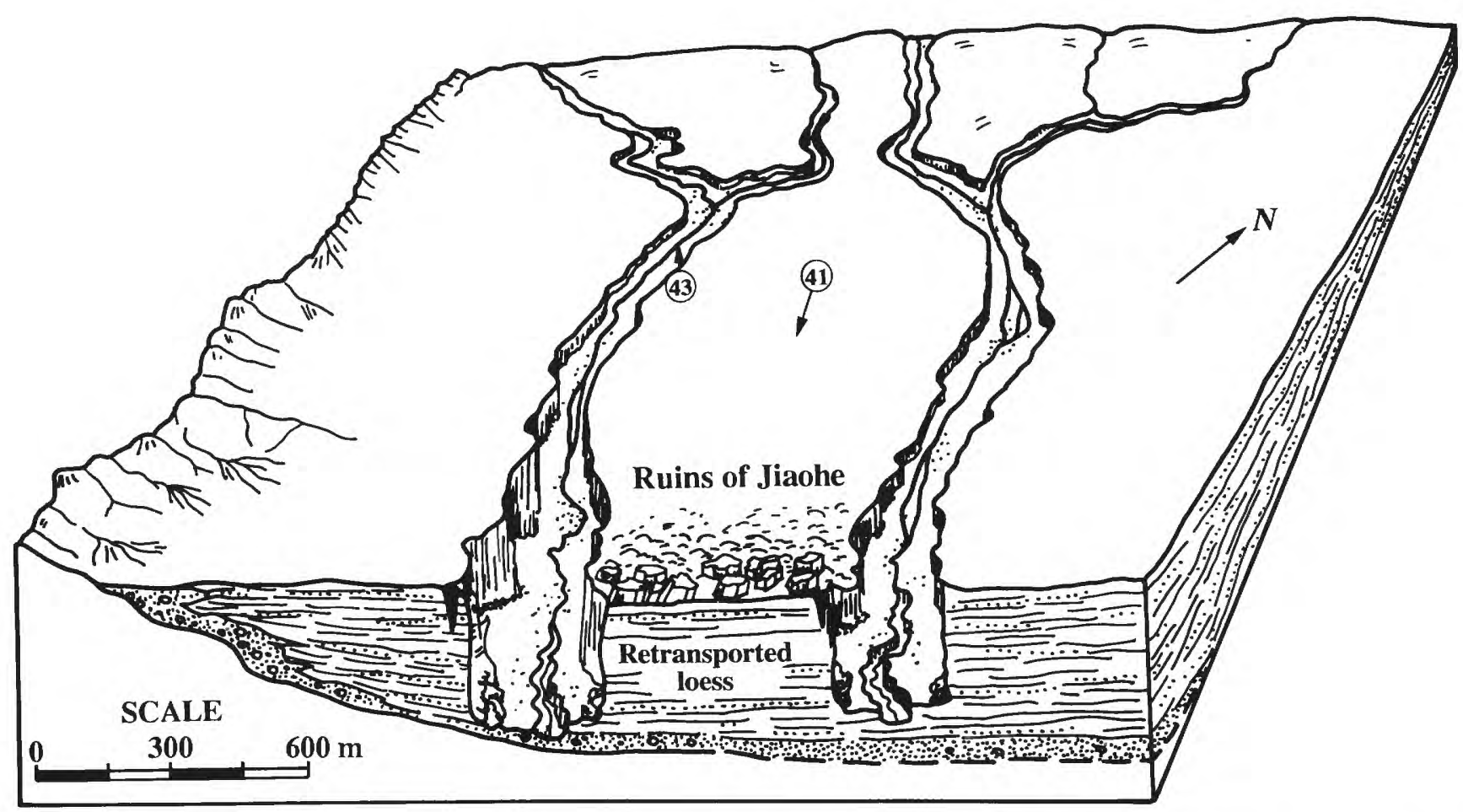

Figure 42. Schematic block diagram of late Pleistocene retransported bedded loess (Wang and Song, 1983) in small valley at Jiaohe $8 \mathrm{~km}$ west of Turpan, Xinjiang Uygur Autonomous Region, China (fig. 1). Arrows on circled num- bers show direction of view of photographs in figures 41 and 43 (fig. 44 faces opposite direction of fig. 41 and also includes southeast end of mesa). Sketch by Mu Guijin, 1986; vertical exaggeration 7.5. $\times$. 


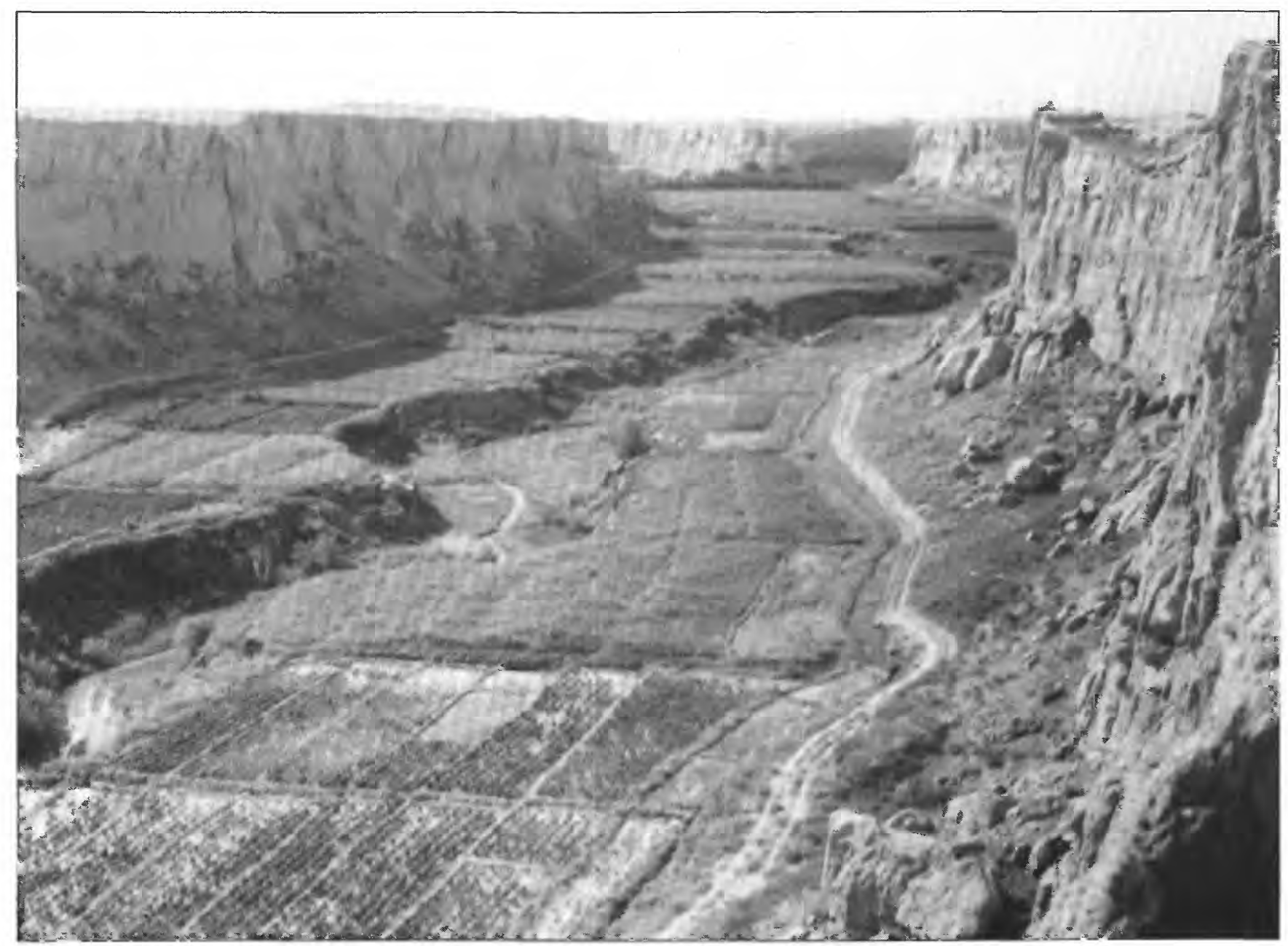

Figure 43. View upstream (northwest) of narrow, irrigated, steep-walled valley entrenched $30 \mathrm{~m}$ into retransported loess on west side of ruins of ancient city of Jiaohe near Turpan, Xinjiang Uygur Autonomous Region, China (figs. 1, 42). Photograph 4898 by Troy L. Péwé, August 5, 1986. 


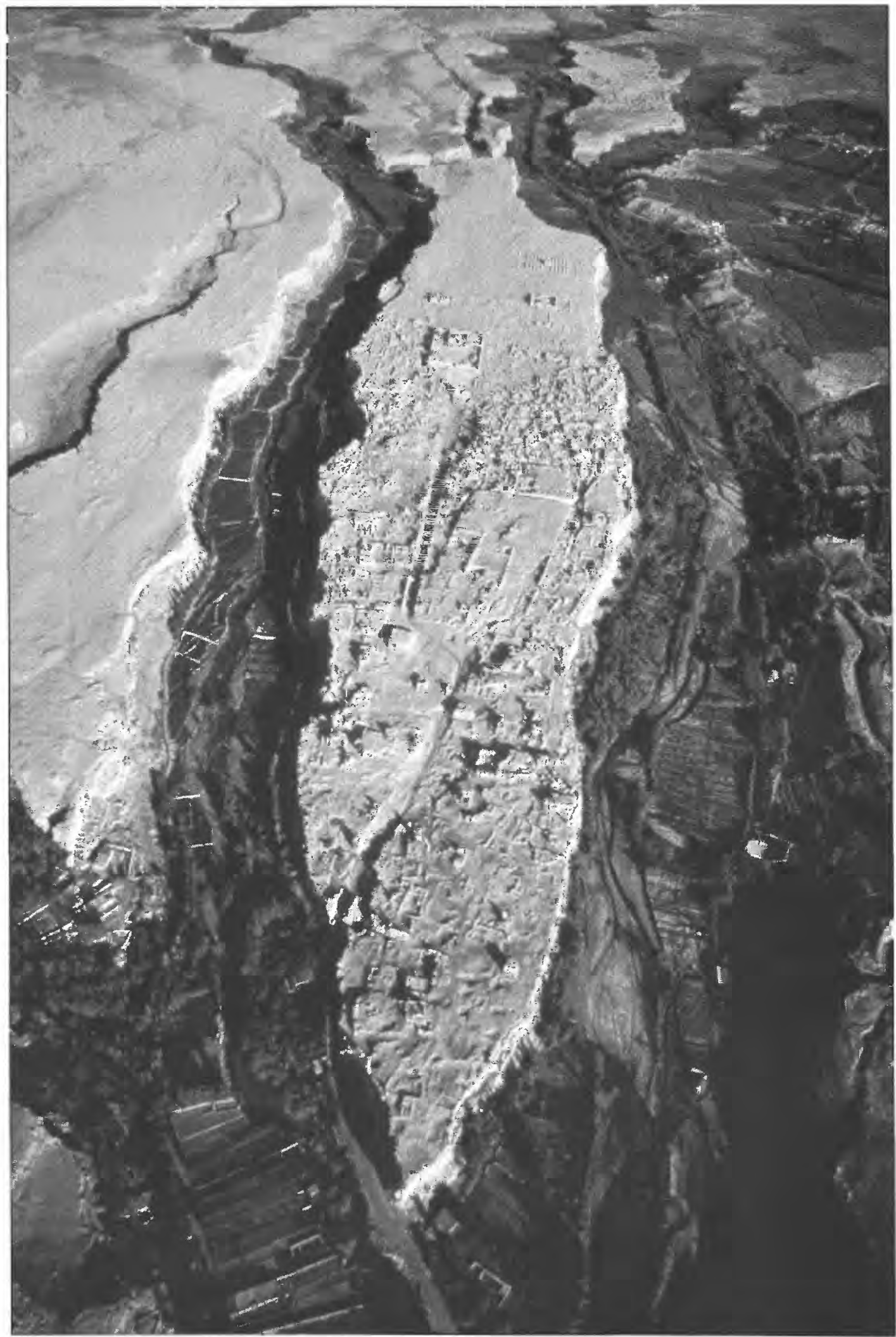

Figure 44. Oblique northwest-facing aerial photograph of mesa-like remnants of retransported loess $8 \mathrm{~km}$ west of Turpan, Xinjiang Uygur Autonomous Region, China (figs. 1, 41, 42). Ruins of ancient city of Jiaohe on mesa outline house structures built of loess bricks. Photograph by Georg Gerster, Copyright National Geographic Society; taken September 5, 1987, at 9:30 a.m., and published with permission. 


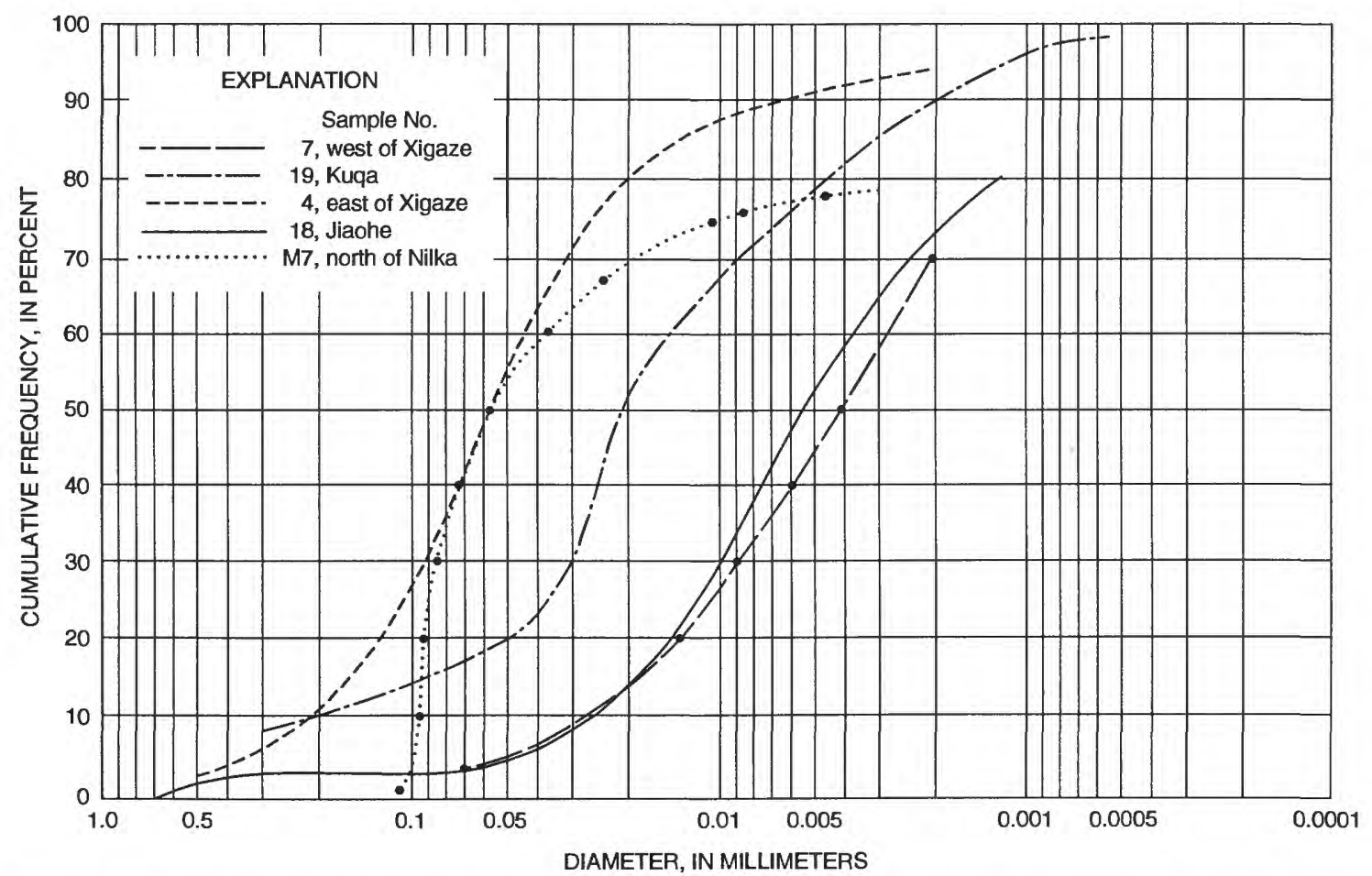

Figure 45. Cumulative-frequency grain-size curves for samples of primary loess and retransported loess from Xinjiang Uygur Autonomous Region in northwestern China (figs. 1, 2) and primary loess and retransported loess from southern Qinghai-Xizang (Tibet) Plateau (fig. 34). Sample 4 is sandy primary loess from east of Xigaze, Xizang Autonomous Region (fig. 34; table 1); M7 is clay-rich primary loess from $15 \mathrm{~km}$ north of Nilka in Ili He valley, Xinjiang Uygur Autonomous Region (figs. 1, 46); 18 and 19 are retransported loess from Xinjiang Uygur Autonomous Region (figs. 1, 2, 5; table 1); and 7 is retransported loess from west of Xigaze (table 1). Samples 4 and 7 collected by T.L. Péwé and analyzed by R.M. Slatt at Cities Service Company, Tulsa, Okla.; samples 18 and 19 collected by T.L. Péwé (Péwé, 1987) and analyzed by Mu Guijin at Arizona State University, Tempe, Ariz.; sample M7 collected and analyzed by Mu Guijin, Institute of Geography, Academia Sinica, Ürümqi, Xinjiang Uygur Autonomous Region, China. Dots are data points.

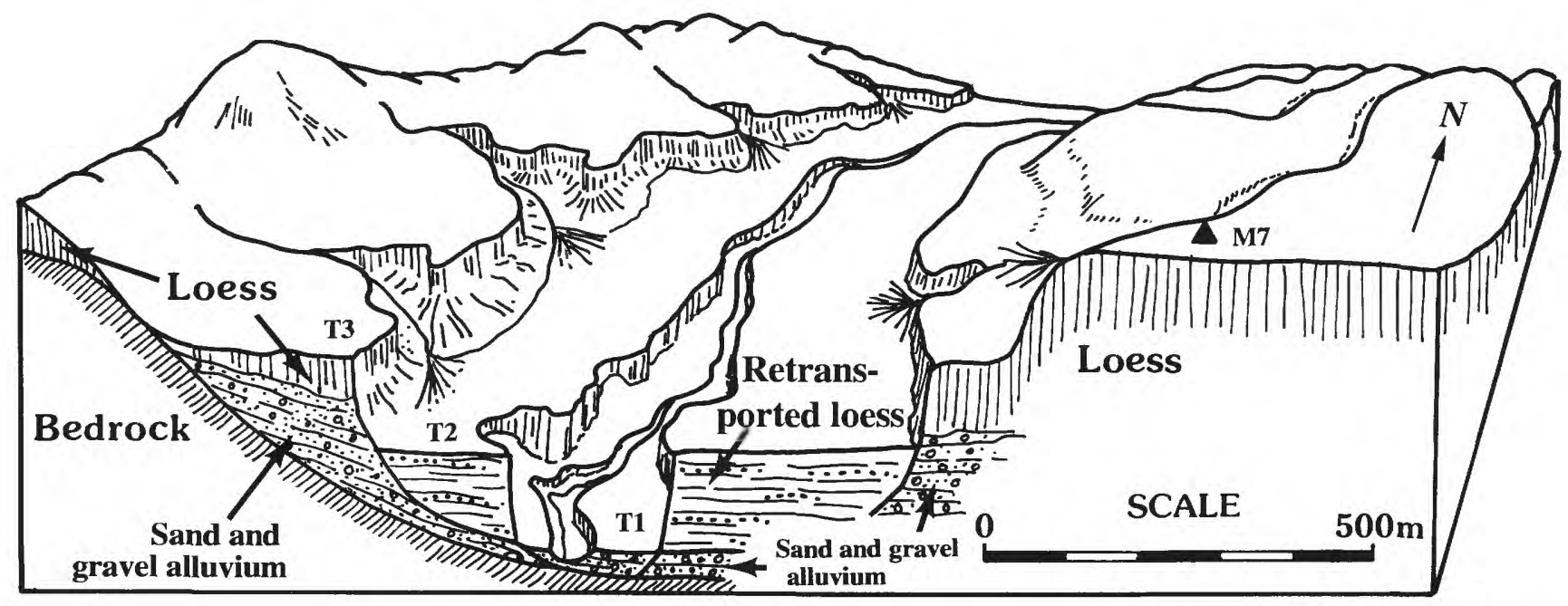

Figure 46. Schematic block diagram of loess and retransported loess $15 \mathrm{~km}$ north of Nilka, in Ili He valley, north slope of Tian Shan in Xinjiang Uygur Autonomous Region, China $(200 \mathrm{~km}$ north of Kuqa) (fig. 1). Valley has three levels of terraces. Primary loess blankets high terrace and uplands, and retransported stratified loess of late Pleistocene to Holocene age is exposed on two lower levels of terraces in valley, beside and over Middle Pleistocene sand-and-gravel alluvium. Retransported loess and terrace scarps are similar to those at Xigaze and elsewhere in the southern part of the Qinghai-Xizang (Tibet) Plateau (figs. 26, 27). T1, terrace number; M7, location of loess sample. Sketch by Mu Guijin in 1986; vertical exaggeration $10 \times$. 


\section{REFERENCES CITED}

Academia Sinica, 1980, A scientific guidebook to south Xizang (Tibet): Beijing, Organizing Committee, Symposium on Qinghai-Xizang (Tibet) Plateau: Beijing, 1980, 104 p.

Andersson, J.G., 1923, Essays on the Cenozoic of northern China: Peking, Geological Survey of China Memoir 3, series A, $152 \mathrm{p}$.

Argand, Emile, 1924, La Tectonique de l'Asie: Congrés Géologique International Comptes Rendus [13th, Bruxelles, Belgium, 1922], p. 170-372.

Barbour, G.B., 1925a, Chinese loess: Association of Chinese and American Engineers Journal, v. 6, no. 4, p. 1-10.

$-1925 \mathrm{~b}$, The loess of China: The China Journal of Science and Arts, v. 3, no. 8, p. 454-463; v. 3, no. 9, p. 509-519.

1930, The loess problem of China: Geological Magazine, v. 67, p. $458-475$.

Berg, L.S., 1960, Less kak produkt vyvetrivaniya i pochvoobrazovaniya, iz Klimat i zhizn [in Russian]: Moscow, Izdatel'stvo Akademii Nauk SSSR. Translated, 1964, as Loess as a product of weathering and soil formation, from Climate and life, selected works of L.S. Berg, Vol. 3: Jerusalem, Israel Program for Scientific Translations, $207 \mathrm{p}$.

Biscayne, P.E., 1964, Distinction between kaolinite and chlorite in recent sediments by $\mathrm{X}$-ray diffraction: American Mineralogist, v. 49, p. 1281-1289.

- 1965, Mineralogy and sedimentation of recent deep-sea clay in the Atlantic Ocean and adjacent seas and oceans: Geological Society of America Bulletin, v. 76, p. 803-832.

Bryan, Kirk, 1927, The "Palouse soil" problem, Chap. B in Contributions to the geography of the United States, 1926: U.S. Geological Survey Bulletin 790, p. 21-46.

Burbank, D.W., and Li Jijun, 1985, Age and paleoclimatic significance of the loess of Lanzhou, north China: Nature, v. 316, p. $429-431$.

Cegla, J., Buckley, T., and Smalley, I.J., 1971, Microtextures of particles from some European loess deposits: Sedimentology, v. 17, p. 129-134.

Chang Cheng-fa and Pan Yu-shen, 1981, A brief discussion on the tectonic evolution of Qinghai-Xizang Plateau, in Liu Dong-sheng, ed., Geological and ecological studies of the Qinghai-Xizang Plateau; Vol. 1, Geology, geological history and origin of Qinghai-Xizang Plateau: Beijing, Science Press, p. 1-18.

Charlesworth, J.K., 1957, The Quaternary era, with special reference to its glaciation: London, Edward Arnold, 2 vols., $1700 \mathrm{p}$.

Chen Deniu, Gao Jiaxiang, Gao Fuquing, and Liu Tungsheng, 1985, Fossil snails and their environment, in Liu Tungsheng, ed., Loess and the environment: Beijing, China Ocean Press, sec. 2, chap. 4, p. 72-84.

Chen Zhiming, 1986, Lake retreat in Qinghai-Xizang Plateau, with additional reference to its climatic significance [in Chinese]: Oceanologia et Limnologia Sinica, v. 17 , no. 3, p. 207-216.

Cheng Guodong, 1983, Vertical and horizontal zonation of highaltitude permafrost, in Proceedings, Fourth International Conference on Permafrost, 1983, Fairbanks, Alaska: Washington, D.C., National Academy of Science, p. 136-141.
Cheng Guodong and Liang Fengzian, 1987, Soil wedge polygons along the Qinghai-Xizang Highway [abs.]: International Union for Quaternary Research, Loess Commission, 12th Congress, Ottawa, Canada, Programme with Abstracts, p. 142.

Cheng Guodong and Wang Shaoling, 1982, On the zonation of high-altitude permafrost in China [in Chinese]: Journal of Glaciology and Cryopedology, v. 4, p. 1-17.

Chinese Academy of Sciences, 1974, A photographic record of the Mount Jolmo Lungma Scientific Expedition (19661968): Beijing, Science Press, 108 p.

Clarke, A.H., 1973, The freshwater mollusks of the Canadian Interior Basin: Malacologia, v. 13, 509 p.

Clarke, A.H., and Harington, C.R., 1978, Asian freshwater mollusks from Pleistocene deposits in the Old Crow Basin, Yukon Territory: Canadian Journal of Earth Sciences, v. 15, p. 45-51.

David-Neel, Alexandra, 1927, My journey to Lhasa: New York, Harper Brothers; republished 1986, Boston, Beacon Press, $310 \mathrm{p}$.

Derbyshire, Edward, 1985, Loess and loessic colluvia in Qinghai Province, China [abs.]: International Conference on Geomorphology, 1st, Manchester, England, 1985, Abstracts of Papers, p. 183.

Feng Zhaodong and Thompson, L.G., 1989, A discussion on multigenesis of the loesses in China and the United States [abs.]: Geological Society of America Abstracts with Programs, v. 21, no. 6, p. A154.

Folk, R.L., 1974, Petrology of sedimentary rocks, 2d edit.: Austin, Tex., Hemphill Publishing Co., 182 p.

Gao Shiyang and Li Bingxiao, 1981, Borate minerals on the Qinghai-Xizang Plateau, in Liu Dong-sheng, ed., Geological and ecological studies of the Qinghai-Xizang Plateau, Vol. 2, Environment and ecology of the Qinghai-Xizang Plateau: Beijing, Science Press, p. 1725-1731.

Han Suyin, 1979, Lhasa, the open city: Frogmore, England, Triad/Panther Books, 192 p.

Harrer, Heinrich, 1953, Seven years in Tibet: Los Angeles, Calif., J.P. Tarcher, Inc., 318 p.

Harvard, Andrew, 1984, The forgotten face of Everest: Washington, D.C., National Geographic Society, National Geographic, v. 166 , no. 1 , p. $71-77$.

Hedin, Sven, 1903, Central Asia and Tibet: London, Hurst and Blackett, Ltd, v. 1, 608 p.; v. 2, 664 p.

Heller, Friedrich, and Liu Tungsheng, 1982, Magnetostratigraphical dating of loess deposits in China: Nature, v. 300, p. 431433.

1984, Magnetism of Chinese loess deposits: Royal Astronomical Society Geophysical Journal, v. 77, p. 125-141.

Heller, Friedrich, Ruegg, Felix, Liu Xiuming, Liu Tungsheng, and Sun Jiangzhong, 1989, Magnetic properties of the loess sediments in China [abs.]: International Geological Congress, 28th, Washington, D.C., v. 2, p. 2-48-2-49.

Huang Wanpo, 1980, The Quaternary mammalian fossil localities from Xizang, in Paleontology of Xizang [in Chinese]: Beijing, Academia Sinica, v. 1, p. 48-53.

Huang Wanpo and Ji Hongxiang, 1981, The climate and uplift of the Qinghai-Xiang (Tibet) Plateau in the late Pleistocene and Holocene, in Liu Dong-sheng, ed., Geological and ecological studies of the Qinghai-Xizang Plateau, Vol. 1, Geology, 
geological history and origin of Qinghai-Xizang Plateau: Beijing, Science Press, p. 225-230.

Huang Xiaoming, Yang Hairong, and Liu Tieliang, 1981, Some behaviors of seasonal freezing and thawing of natural ground in the interior of Qinghai-Xizang Plateau, in Liu Dongsheng, ed., Geological and ecological studies of the QinghaiXizang Plateau, Vol. 2, Environment and ecology of Qinghai-Xizang Plateau: Beijing, Science Press, p. 18031816.

Huc, E.R. and Gabet, Joseph, 1928, Travels in Tartary Tibet and China-1844-1846: London, George Routledge and Sons, Ltd., v. 1, 387 p.; v. 2, 406 p.

Kidd, W.S., Pan Yusheng, Chang Chengfa, Coward, M.P., Dewey, J.F., Gansser, H., Molnar, P., Shackleton, R.M., and Sun Yiyin, 1988, Geological mapping of the 1985 Chinese-British Tibetan (Xizang-Qinghai) Plateau geotraverse route: Royal Society of London Philosophical Transactions, v. 327, p. 287-305, scale 1:500,000.

Kreig, R.A., Cheng Guodong, and Brown, Jerry, 1986, Terrain analysis from space shuttle photographs of Tibet: American Society of Civil Engineers, International Conference on Cold Regions Engineering, 4th, Anchorage, Alaska, 1986, Proceedings, p. 400-409.

Kuhle, Matthias, 1985, Permafrost and periglacial indicators on the Tibetan Plateau from the Himalaya Mountains in the south to the Quilian Shan in the north $\left(28^{\circ}-40^{\circ} \mathrm{N}\right)$ : Zeitschrift für Geomorphologie, v. 29, no. 2, p. 183-192. -1986, The upper limit of glaciation in the Himalayas: GeoJournal, v. 13 , no. 4 , p. 331-346.

Lanzhou Institute of Glaciology and Cryopedology, 1983, The tentative map on snow, ice and frozen ground in China: Beijing, Academia Sinica, scale 1:4,000,000.

Li Bingyuan and Li Jijun, 1991, Quaternary glacial-distribution map of the Qinghai-Xizang (Tibet) Plateau [in Chinese and English]: Beijing, Science Press, 10 p., scale 1:3,000,000.

Li Bingyuan, Wang Fubao, Zhang Qingsong, and others, 1983, Quaternary geology in Xizang, the series of the scientific expedition to Qinghai-Plateau [in Chinese]: Beijing, Science Press, $192 \mathrm{p}$.

Liu Dong-sheng ${ }^{6}$, ed., 1981, Geological and ecological studies of Qinghai-Xizang Plateau: Beijing, Science Press, v. 1 p. 1974, v. 2, p. 975-2138.

Liu Tungsheng, ed., 1987, Aspects of loess research: Beijing, China Ocean Press, 477 p.

Liu Tungsheng, 1988, Loess in China: Berlin, Heidelberg, Springer-Verlag, $234 \mathrm{p}$.

Liu Tungsheng, ed., 1991, Loess, environment and global change: Beijing, Science Press, 288 p.

Liu Dongsheng and Chang Tsunghu, 1964, The "Huangtu" (loess) of China: International Congress on the Quaternary, 6th, Warsaw, 1961, Report, v. 4, p. 503-523.

Liu Dongsheng and Ding Menglin, 1984, The characteristics and evolution of the palaeoenvironment of China since the late Tertiary, in Whyte, R.D., ed., The evolution of the east Asian environment; Vol. 1, Geology and palaeoclimatology: University of Hong Kong, Centre of Asian Studies, p. 11-40.

\footnotetext{
${ }^{6}$ Previously published variations on Liu's given name include Dongsheng, Dong-sheng, Tongsheng, Tong-sheng, Tungsheng, and Tung Sheng.
}

Liu Tongsheng and Wang Kelu, 1965, Loess deposits of China [in Chinese]: Beijing, Science Press, 244 p.

Liu Tungsheng and Yuan Baoyin, 1982, Quaternary climatic fluctuation-A correlation of records in loess with that of deep sea core V28-238, in Research on geology (I) [in Chinese with English abstract]: Beijing, Academia Sinica, Cultural Relics Publishing House, Institute of Geology, p. 113-121.

Liu Dongsheng and others, 1964, Loess of the middle reaches Huang He [Yellow River] valley [in Chinese]: Beijing, Science Press, $234 \mathrm{p}$.

Liu Tongsheng and others, 1966, The composition and texture of loess [in Chinese]: Beijing, Academia Sinica, Science Press, $132 \mathrm{p}$.

Liu Tung Sheng, Gu Xiong Fei, An Zhi Sheng, and Fan Yong Xiang, 1981, The dust fall in Beijing, China, on April 18, 1980, in Péwé, T.L., ed., Desert dust-origin, characteristics, and effect on man: Geological Society of America Special Paper 186, p. 149-157.

Liu Tungsheng and others, 1985, Loess and the environment: Beijing, China Ocean Press, 251 p.

Lozek, Vogen, 1964, Quartarmollusken der Tschechoslowakei: Prague, Akademie der Wissenschaften, Verlag der Tschechslowakischen, v. 31,374 p., $32 \mathrm{pl}$.

Lhalungpa, L.P., 1983, Tibet, the sacred realm: New York, Aperture, Inc. $159 \mathrm{p}$.

McGovern, W.M., 1924, To Lhasa in disguise: New York, Grosset and Dunlap, $462 \mathrm{p}$.

Mertie, J.B., Jr., 1937, The Yukon-Tanana region, Alaska: U.S. Geological Survey Bulletin 872, 276 p.

Meteorological Bureau, Xizang Autonomous Region, 1983, Xizang climatic data (1951-1980): $1079 \mathrm{p}$.

Molnar, Peter, 1989, The geologic evolution of the Tibetan Plateau: American Scientist, v. 77 , p. 350-360.

Pavlinov, V.I., 1959, Some data about the genesis of Chinese loess, in Popov, V.V., ed. Loess of northern china; Proceedings of the Commission for the Study of the Quaternary Period [in Russian]: Moscow, Izdatel'stvo Akademii Nauk SSSR, v. 14. Translated, 1964, by Program for Scientific Translations, Jerusalem, Israel, p. 57-84.

Pésci, Marton, 1965, Genetic classification of the deposits constituting the loess profiles of Hungary: Budapest, Academiae Scientiarum Hungaricae Acta Geologica, v. 9, p. 65-84.

1967, Horizontal and vertical distribution of the loess in Hungary: Krakow, Studia Geomorphologica Corpatho-Balcanica, v. 1, p. 13-20.

Péwé, T.L., 1951, An observation on wind-blown silt: Journal of Geology, v. 59, p. 399-401.

1955, Origin of the upland silt near Fairbanks, Alaska: Geological Society of America Bulletin, v. 66, p. 699-724.

1968, Loess deposits of Alaska: International Geological Congress, 23rd, Prague, 1968, Report, v. 8, p. 297-309.

1975a, Quaternary geology of Alaska: U.S. Geological Survey Professional Paper 835, 145 p.

1975b, Quaternary stratigraphic nomenclature in unglaciated central Alaska: U.S. Geological Survey Professional Paper 862, 32 p.

1980a, A geologist in Tibet-National Science Foundation trip report: Tempe, Ariz., Arizona State University, manuscript in files of Geology Department, $37 \mathrm{p}$. 
1980b, Report of the Symposium of the Qinghai-Xizang (Tibet) Plateau 1980: Innsbruck, Austria, Zeitschrift für Gletscherkunde und Glazialgeologie, v. 16, no. 1, p. 135-144. 1981, Tibetan science updated: Geotimes, v. 26, no. 1, p. $16-20$.

1986a, A report on the Third Chinese Conference on Permafrost-China expands research on frozen ground: The Northern Engineer, v. 18, p. 1-8.

$1986 \mathrm{~b}$, China expands research in frozen ground-a report of the Third Chinese Conference on Permafrost: Innsbruck, Austria, Zeitschrift für Gletscherkunde und Glazialgeologie, v. 22, p. 89-95.

1987, Retransported loess on the south side of the Tian Shan, Xinjiang Uygur Autonomous Region, northwestern China [abs.]: Geological Society of America Abstracts with Programs, v. 19, no. 7, p. 804.

Péwé, T.L., and Holmes, G.W., 1964, Geology of the Mt. Hayes D-4 quadrangle, Alaska: U.S. Geological Survey Miscellaneous Geological Investigations Map I-394, scale $1: 63,360$.

Péwé, T.L., and Journaux, André, 1983, Origin and character of loesslike silt in unglaciated south-central Yakutia, Siberia, U.S.S.R: U.S. Geological Survey Professional Paper 1262, $46 \mathrm{p}$.

Péwé, T.L., Liu Tung-Sheng, and Slatt, R.M., 1981a, Loess in southern Tibet [abs.]: Geological Society of America Abstracts with Programs, v. 13, no. 7, p. 528.

1985, Loess in southern Tibet [abs.], in Proceedings (abstracts) of the International Symposium on Loess Research, Xian, 1985: Beijing, Academia Sinica, p. 29.

1987, Retransported loess in the southern part of the Qinghai-Xizang (Tibet) Plateau, China, in Liu Tungsheng, ed., Aspects of loess research: Beijing, China Ocean Press, p. 70-73.

Péwé, T.L., Péwé, E.A., Péwé, R.H., 1976, Rate of desert dust deposition [abs.]: Arizona Academy of Science Journal, v. 11, Proceedings Supplement, p. 95-96.

Péwé, T.L., Péwé, E.A., Péwé, R.H., Journaux, André, and Slatt, R.M., 1981b, Desert dust-characteristics and rates of deposition in central Arizona, in Péwé, T.L., ed., Desert dustorigin, characteristics, and effect on man: Geological Society of America Special Paper 186, p. 169-190.

Péwé, T.L., Westgate, J.A., and Stemper, B.A., 1989, Refinement of age interpretation of Quaternary events in Fairbanks area, Alaska [abs.]: International Geological Congress, 28th, Washington, D.C., 1989, Abstracts, v. 2, p. 2-602.

Pradyumna, P.K., 1976, The changing face of Tibet: Lexington, Ky., University of Kentucky Press, 114 p.

Pumpelly, Raphael, 1867, Geological researches in China, Mongolia, and Japan: Washington, D.C., Smithsonian Contributions to Knowledge, no. 202, v. 15 , no. 143 p.

-1879 , Relation of secular rock disintegration to loess, glacial drift, and rock basins: American Journal of Science and Arts, v. 17, p. 133-144.

Pye, Kenneth, 1987, Aeolian dust and dust deposits: London, Academic Press, 334 p.

Rawling, C.G., 1905, The great plateau: London, Edward Arnold, $319 \mathrm{p}$.

Reiter, R., and Reiter, G.J., 1981, Tibet-the last frontier: American Meteorological Society Bulletin, v. 62, no. 1, p. 4-13.
Richthofen, F.P.W. von, 1877, China: Berlin, D. Reimer, v. 1, 758 p. [In German.]

- 1882, On the mode of origin of the loess: Hertford, England, Geological Magazine, decade 2, vol. 9, p. 293-305.

1886, Fuher für Forschungsreisende: Hanover, Germany, $734 \mathrm{p}$.

Russell, R.J., 1944, Lower Mississippi Valley loess: Geological Society of America Bulletin, v. 55, p. 1-40.

Rutter, Nat, Ding Zhongli, and Liu Tungsheng, 1991, Comparison of isotope stages $1-61$ with the Baoji-type pedostratigraphic section of north-central China: Canadian Journal of Earth Sciences, v. 28, p. 985-990.

Schultz, L.G., 1964, Quantitative interpretation of mineralogical composition from X-ray and chemical data for the Pierre Shale: U.S. Geological Survey Professional Paper 391-C, $31 \mathrm{p}$.

Sengör, A.M.C., 1981, Symposium on Qinghai-Xizang (Tibet) Plateau-Beijing (Peking), China: Eos, Transactions, American Geophysical Union, v. 62, no. 30, p. 601-603.

Shi Yafeng, ed., 1980, Glaciers in China: Shanghai, Shanghai Scientific and Technical Publishers. [ 100 p. $]$

1988, Map of snow, ice, and frozen ground in China: Beijing, China Cartographic Publishing House, Lanzhou Institute of Glaciology and Geocryology, scale 1:4,000,000 [explanation, $32 \mathrm{p}$ ].

Shi Yafeng, Hsieh Tzechu, Chang Penhsing, and Le Chichum, 1980, Distribution, features and variations of glaciers in China, in World glacier inventory: Gentbrugge, Belgium, International Association of Scientific Hydrology Publication 126, p. 111-116.

Shi Yafeng and Li Jijun, 1980, A glaciological research of the Qinghai-Xizang Plateau, in Organizing Committee, Proceedings of Symposium on Qinghai-Xizang (Tibet) Plateau [abs.]: Beijing, Academia Sinica, p. 221-222.

1981, Glaciological research of the Qinghai-Xizang Plateau in China, in Liu Dong-sheng, ed., Geological and ecological studies of Qinghai-Xizang Plateau; Vol. 2, Environment and ecology of Qinghai-Xizang Plateau: Beijing, Science Press, p. 1589-1597.

Shi Yafeng, Zheng Benxing, and Li Shijie, 1992, Last glaciation and maximum glaciation in the Qinghai-Xizang (Tibet) Plateau-a controversy to $M$. Kuhle's ice sheet hypothesis: Zeitschrift für Geomorphologie, Supplement, v. 84, p. 1935.

Sîs, Vladimír, and Vaniš, Josef, no date [late 1940's?], On the road through Tibet: London, Spring Books, 51 p., 224 photo pls., printed in Czechoslovakia, translated by Iris Urwin.

Slatt, R.M., and Eyles, Nicholas, 1981, Petrology of glacial sand-implications for the origin and mechanical durability of lithic fragments: Sedimentology, v. 28, p. 171-183.

Smith, H.T.U., and Fraser, H.J., 1935, Loess in the vicinity of Boston, Massachusetts: American Journal of Science, 5th series, v. 30 , p. 16-32.

Sorkhabi, R.B., and Stump, Edmund, 1993, Rise of the Himalaya-a geochronologic approach: Geological Society of America, GSA Today, v. 3, no. 4, p. 85, 88-92.

Sun Jianzhong and Li Xingguo, 1986, Environment during the last glaciation, North China [in Chinese]: Xian College of Geology, 18 p. 
Swineford, Ada, and Frye, J.C., 1945, A mechanical analysis of wind-blown dust compared with analyses of loess: American Journal of Science, v. 243, p. 249-255.

Taber, Stephen, 1943, Perennially frozen ground in Alaska-its origin and history: Geological Society of America Bulletin, v. 54, p. $1433-1548$.

Tong Boliang, 1981, Some features of permafrost of the QinghaiXizang Plateau and the factors influencing them, in Liu Dong-sheng, ed., Geological and ecological studies of the Qinghai-Xizang Plateau; Vol. 2, Environment and ecology of the Qinghai-Xizang Plateau: Beijing, Science Press, p. 1795-1801.

Tomirdiaro, S.V., 1972, Permafrost and economic development of uplands and plains [in Russian]: Magadan, Knigoizdat, $174 \mathrm{p}$.

Trainer, F.W., 1961, Eolian deposits of the Matanuska Valley agricultural area, Alaska: U.S. Geological Survey Bulletin 1121-C, p. C1-C35.

Twenhofel, W.H., 1932, Treatise on sedimentation: Baltimore, Md., Williams and Wilkins, $926 \mathrm{p}$.

Udden, J.A., 1898, The mechanical composition of wind deposits: Rock Island, Ill., Augustana Library Publications 1, 69 p.

U.S. Government Printing Office, 1971, People's Republic of China, Atlas: Washington, D.C., 82 p.

Wang Baolai and French, H.M., 1994, Climate controls and highaltitude permafrost, Qinghai-Xizang (Tibet) Plateau, China: Permafrost and Periglacial Processes, v. 5, No. 2, p. 87-100.

Wang Fubao and Fan, C.Y., 1987, Climatic changes in the Qinghai-Xizang (Tibetan) region of China during the Holocene: Quaternary Research, v. 28, p. 50-60.

Wang Fubao and $\mathrm{Li}$ Bingyuan, 1983, Introduction, in $\mathrm{Li}$ Bingyuan, Wang Fubao, Zhang Qingsong, and others, Quaternary geology in Xizang, the series of the scientific expedition to the Qinghai-Plateau [in Chinese]: Beijing, Science Press, p. 1-15.

Wang Shaoling and Yao Heqing, 1981, Pingos of the Qingshui River valley in Qinghai-Tibetan Plateau [in Chinese]: Journal of Glaciology and Cryopedology, v. 3, no. 3, p. 58-62.

Wang Shuji, Yan Shun, Mu Guijin, and Gao Cunbai, 1991, Quaternary deposits and neotectonics in the southern Tian Shan area: International Union for Quaternary Research, 13th Congress, Beijing, 1991, Excursion Guidebook I, 32 p.

Wang Yongyan and Song Hanliang, eds., 1983, Rock desert, gravel desert, sand desert and loess: Xian, Shannxi People's Art Publishing House, $186 \mathrm{p}$.

Wang Yongyan, Teng Zhihong, and Lue Leping, 1982, Microtextures of loess and the genesis of loess in China, in Liu Tungsheng, ed., Quaternary geology and environment of China: Beijing, China Ocean Press, Quaternary Research Association of China, p. 43-48.

Wang Yongyan and Zhang Zonghu, eds., 1980, Loess in China: Xian, Shannxi People's Art Publishing House, 169 p.

Ward, F.K., 1926, The riddle of the Tsangpo Gorges: London, Edward Arnold, $328 \mathrm{p}$.

Warn, G.F., 1953, Drought and dust on the plains: Weatherwise, v. 6, p. 67-71.

Warn, G.F., and Cox, W.H., 1951, A sedimentary study of dust storms in the vicinity of Lubbock, Texas: American Journal of Science, v. 249, p. 553-568.
Willis, Bailey, Blackwelder, Eliot, and Sargent, R.H., 1907, Research in China, Vol. 1, Part 1, Descriptive topography and geology: Carnegie Institution of Washington Publication 54, $353 \mathrm{p}$.

Xie Yingqin, 1982, The temperature condition of permafrost development in the Qinghai-Xizang Plateau, in Proceedings of the Symposium on Glaciology and Cryopedology, Lanxhou [in Chinese]: Beijing, Science Press, Academia Sinica, p. 1-6.

Xu Shuying, 1980, Evolution of paleographical environment of the Tanggula Mountains Pliocene-Quaternary [abs.]: in Organizing Committee, Proceedings of Symposium on Qinghai-Xizang (Tibet) Plateau: Beijing, Academia Sinica, p. 253.

1981, The evolution of the paleogeographic environments in the Tanggula Mountains in the Pliocene-Quaternary, in Liu Dong-sheng, ed., Geological and ecological studies of the Qinghai-Xizang Plateau; Vol. 1, Geology, geological history and origin of Qinghai-Xizang Plateau: Beijing, Science Press, p. 247-255.

Xue Xiangxu, 1984, The Quaternary mammalian fossils in the loess area of China, in Sadao Sasajima and Wang Yongyan, eds., The recent research of loess in China: Kyoto, Japan, Kyoto University and Northwest University, p. 112-159.

Yang Yichou, Li Bingyuan, and Yin Zeheng, 1983, Geomorphology of Xizang (Tibet): Beijing, Science Press, 238 p.

Yang Yichou, Li Bingyuan, Yin Zeheng, Zhang Qingson, and Wang Fubao, 1981: Basic characteristics of landforms on the Xizang Plateau, in Liu Dong-sheng, ed., Geological and ecological studies of Qinghai-Xizang Plateau; Vol. 2, Environment and ecology of Qinghai-Xizang Plateau: Beijing, Science Press, p. 1745-1757.

Yuan Fangee, Mu Guijin, and Yan Shan, 1983, Loess of Tian Shan, China [in Chinese]: Ürümqi, Xinjiang Geography, v. 6 , no. 4.

Zeuner, F.E., 1949, Frost soils on Mount Kenya, and the relation of frost soils to aeolian deposits: Oxford, England, Journal of Soil Science, v. 1, p. 20-30.

Zhadin, V.L., 1952, Mollusks of fresh and brackish waters of the U.S.S.R.-keys to the fauna of the U.S.S.R.: Academy of Sciences of the U.S.S.R. Zoological Institut, no. 46, 357 p. Translated from Russian by Gourevitch, A., 1965, from Moskva-Leningrad, Izdatel'stvo Akademii Nauk SSSR., by Israel Program for Scientific Translations, Ltd., Jerusalem, 384 p. [Available from U.S. Department of Commerce, Springfield, Va.]

Zhang Linyuan, Dai Xuerong, and Shi Zhenguao, 1991, The sources of loess material and the formation of the loess plateau in China, in Okuda, Setsuo, Rapp, Anders, and Zhang Linyuan, eds., Loess, geomorphological hazards and processes: Catena Supplement 20, p. 1-14.

Zhao Sichu, Ge Xudong, and Gao Fuqing, 1976, Quaternary stratigraphy of the Mt. Himalaya area, in Academia Sinica, The scientific exploration team of Xizang, report of the scientific exploration in the Mt. Himalaya area- Quaternary geology [in Chinese]: Beijing, Science Press, p. 2-28.

Zheng Benxing and Jiao Keqin, 1991, Quaternary glaciations and periglaciations in the Qinghai-Xizang (Tibetan) Plateau: International Union for Quaternary Research, 13th Congress, Beijing, 1991, Excursion Guidebook XI, 54 p. 
Zheng Benxing and Shi Yafeng, 1976, A discussion on the Quaternary glaciation of the Mt. Himalaya area, in Academia Sinica, The scientific exploration team of Xizang, report of the scientific exploration in the Mt. Himalaya areaQuaternary geology [in Chinese]: Beijing, Science Press, p. 29-62.

Zheng Du, Zhang Yong-zu, and Yang Qin-ye, 1981, Physico-geographical differentiation of the Qinghai-Xizang Plateau, in
Liu Dong-sheng, ed., Geological and ecological studies of the Qinghai-Xizang Plateau; Vol. 2, Environment and ecology of the Qinghai-Xizang Plateau: Beijing, Science Press, p. $1851-1860$.

Zhou Kunshu, Liang Xiulong, Ye Yongying, and Wang Wenlin, 1960, Sporo-pollen and plant relics of buried soils in older loess at Chenjiaya of Wangjiagou, Lishi County, Shanxi Province: Quaternaria Sinica, v. 1, p. 104-111. 
